\title{
Fngineering Experiment Station
}

Universily of Illinois

August 31, 1955

Technical Report No. 14

PRINCIPLES AND PROCESSES ROR REMOVING

NITROGEN OXIDES FROM GASES

by

M. S. Peters

Contract No. Ars $(11-1)-276$

U. S. Atomic Bnergy Commission.

H. F. Johnstone, Technical Director 


\section{DISCLAIMER}

This report was prepared as an account of work sponsored by an agency of the United States Government. Neither the United States Government nor any agency Thereof, nor any of their employees, makes any warranty, express or implied, or assumes any legal liability or responsibility for the accuracy, completeness, or usefulness of any information, apparatus, product, or process disclosed, or represents that its use would not infringe privately owned rights. Reference herein to any specific commercial product, process, or service by trade name, trademark, manufacturer, or otherwise does not necessarily constitute or imply its endorsement, recommendation, or favoring by the United States Government or any agency thereof. The views and opinions of authors expressed herein do not necessarily state or reflect those of the United States Government or any agency thereof. 


\section{DISCLAIMER}

Portions of this document may be illegible in electronic image products. Images are produced from the best available original document. 
Engineering Experiment Station

Unifersity of Illinois

August 31, 1955

Technical Report No. 14

PRINCI ILES AND PROCESSES FOR REMOVING

NITBOGEN OXIDES FROM GASES

by

M. S。 Poters

Contract No. AP $(11-1)-276$

U. S.Atomic Energy Commission

H. F. Johnstone, Technical Direct or 


\section{DISTRIBUTION IIST}

Copies

Copy No.

1

5

1

1

1

3

1

3

1

2

2

5

$\frac{1}{2}$
Dr. M. D. Thomas (Stanford Research Institute)

1

Argonne National Laboratory (Young)

Armed Forces Special Weapons Project

Army Chemical Center (Technical Library)

Army Chemical Corpi (Camp Detrick)

Atomic Energy Couwission, Washington (Technical Library)

Dr. H. W. Russell (Battelle Memorial Institute)

Brookhaven National Laboratory

Bur. Med., Navy Department (Code 74)

Carbide and Carbon Chemicals Company, ORNI (K-25)

Carbide and Carbon Chemicals Company, ORNL (Y-12 Area)
Carbide and Carbon Chemicals Company, ORNI (Struxness)

AEC Chicago Patent Group

AEC Chicago Operations Office

Chief of Naval Research, Vashington (Code 209)

du Pont Company, Atomic Energy Division

General Electric Company (ANPP)

General Electric Company (Richland)

AEC Hanford Operations Office

Dr. Philip Drinker (Harvard School of Public Health).

Harvard University, office for Government Contracts (Thomas) AEC Idaho Operations Office

Iowa State College (Fisher)

Dr, Abel Wnlman (Johns Fopkins. University)

Kaiser Engineers, Atomic Energy Division

General Electric Company, (KAPI)

AEC Los Alamos Field office

Ios Alamos Scientific Laboratory

Mallinckrodt Chemical Works (Thayer)

Prof. Rolf Eliassen (Massachusetts Inst. of Technology)

Massachusetts Institute of Technology (Kaufman)

AE'C Mound Laboratory

National Bureau of Standards (Huntoon)

National Lead Corpany of Ohio

Naval Radiological (Defense Laboratory

Naval Research Laboratory (Ramskill)

Mr. C. E. Lapple (Stanford Research Institute)

Phillips Petroleum Company, Atomic Energy Division

North American Aviation, Inc. Atomic Energy Research Div. AtC Savannah River Operations Office. (Wilmington)

AEC Savannah River Operations Office (Augusta)

AEC Santa Fe Operations Office (Tyler)

AEC Schenectady Operations Office

AEC Patent Branch, Washington

U.S. Public Health Service (Terrill)

AEC Technical Information Service, Oak Ridge

UCLA Medical Research Laboratory (Warren)

University of California Radiation Laboratory (Thaxter)

University of California Los Angeles (Baurmash)

University of Rochester, Atomic Energy Project
2-6

7 .

8

9

10-12

13

14-16

17

18-19

20-21

22-26

27

28-32

33

$34-38$

$39-40$

$41-45$

46

$47-48$

49

$50-54$

55

56

57

58-60

$61-62$

$63-68$

69

70

71

72-73

74

$75-76$

77

78

79

80-81

82

83-84

85- 87

88-89

90

91

92

93-167

168

169-171

172

$173-174$ 


\section{DISTRIBUTION LIST}

(Continued)

Copy No.

3 Westinghouse Electric Corporation, Atomic Power Division $175-177$ Arthur D. Iittle, Inc. (Smith)

2 Dow Chemical Company, Rocky Flats

$178-179$

$180-181$

1 Dr. W. P. Yant, (Mines Safety Appliances Company)

$182-186$ Dr. Lyle Gilbertson (Air Reduction Company)

1. Dr. Lyle Gilbertson (Air Reduction Company)

1 Naval Research Laboratory (Anders on)

1 Naval Medical Researoh, Divizion of Alumlc Medicine

1 Library of Congress, Acquisitions Department

1 Picatinny Arsenal, Tech. Inform. Sec: 


\section{FOREWORD}

The work presented here is a part of a program of fundamental research on aerosols related to practical problems in atmospheric pollution and gasmpurifieation operations. The program on the removal of nitrogen oxides from gases was started in June, 1952 as part of Contract Number AP (30-3)-28 with the U. S. Atomic Bnergy Commission, and was ontinued on Contract Number AT(11-1)-276 in september. 1953. The original purpose of the work was to develop improved methods for removing nitrogen oxides from gaseous mixtures and to obtain fundamental understanding of the principles governing the removal operations. This object has been attained during the three years of active research since the start of the program. Progress made during this peried hes been presented in the ipgular monthly iroports and. In Annual Progress Reports and Program Out lines IIHoES-43, May 31, 1952: ILU-ESe56, April 30, 1953: ILU-BS-70, April 30, I954; and ILU-ES-82, Nareh 10, 1955. A summary of the research results. for the period from June $I_{0} 1952$ to August 15, 1953, was presented in Technical Report Namber $10(600-1011)$ 。 The following articles have been published or submitted to technical journals for publication: Controlling Mechanism in the Aqueous Absorption of Nitrogen Orides" by M.S. Peters, G.P.Ross, and J。E。 Klein, A. I. Gh. E. Journal, 1. 105 (1955): "Stop Pollation by Nitrogen Oxides by M.S. Peters Ghem. Eng.。 62. (5), 197 (1955): VVapor and Liquid Phase Reactions Between Nitrogen Dioxide and Water by M.S. Peters and J. I. Holman, aceepted for publication in Ind. Eng. Chem. (1955). 


\section{III}

The report is divided into sections giving the results of individual phases of the research program. These studes: fere carried out by Besearch Assistants under the direction of M. S Peters and. B. F. Johnstone. The work dealing with the multistage bubble-cap column was performed by Jo E. Klein. The study on the vapor and liquid phase reactions between nitrogen oxides and water was conducted by J. Ho Holman. The work on the absorption of nitrogen oxides in caustic solutions was performed by Lo Goldstein. The Venturi atomizer studies and part of the frittedobubbler work was conducted by $I$. B. Andersen. 
TABIP OF CONTENTS

Page

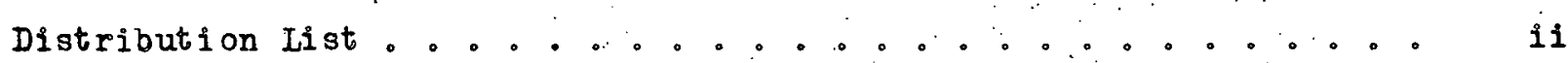

Foreword ............................... iv

Abstract . . . . . . . . . . . . . . . . . . xI

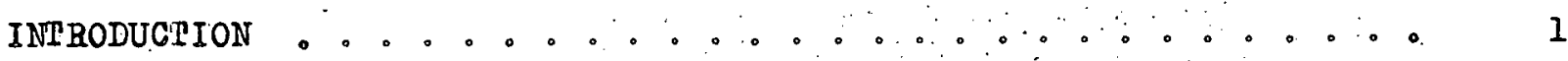

A. Chemistry of the Aqueous Reactions of Nitrogen Oxides $\cdots$ : : 2

PART I. CONTROLLING MEGHANISM IN THE AQUEOUS ABSORPTION OF NITROGEN

OXIDES . $\ldots \ldots \ldots \ldots \ldots$

A. Plate Efficiency o. . . . . . . . . . . . . . 6

1. Chemical Reaction Rates as Controlling Factor . . ... 6

2. Gaseous Diffusion as Controling Factor . ....... 6

PART II. VAPOR AND LIQUID PHASE BHACTIONS BETWEHN NITROGEN DIOXIDE

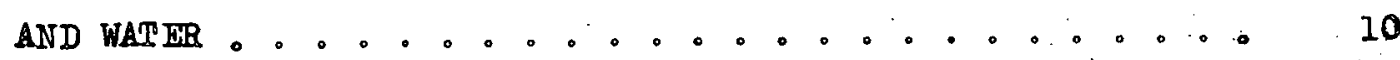

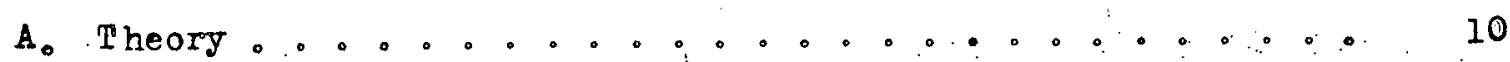

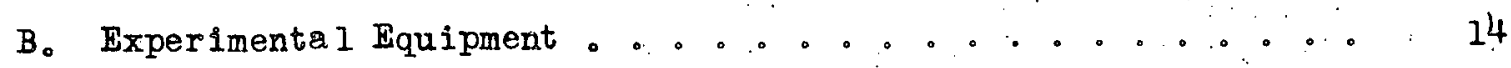

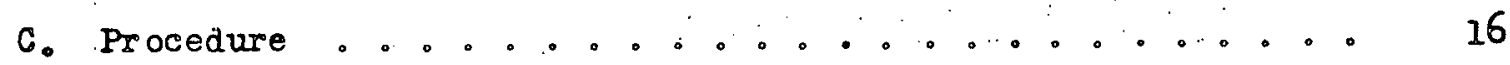

D. Discussion of Results ................ . . 19

E. Summary of Study on Vapor and Liquid Phase Reections . . . 23

PART III. DISPERSION BY VITTURI ATOMIZER AND FRITTED BUBBIIER FOR

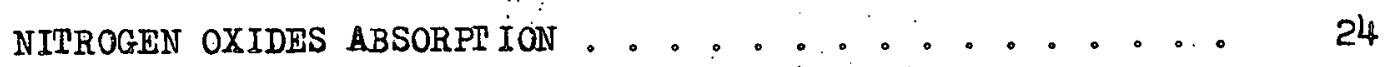

A. Experimental Equipment ............... . . 24

1. Venturi Atomizer o. . . . . . . . . 24

2. Fritted Bubbler . . . .............. 25 
TABIE OF CONPENTS (Continued)

Page

B. Analytical Procedure ................ . . . 25

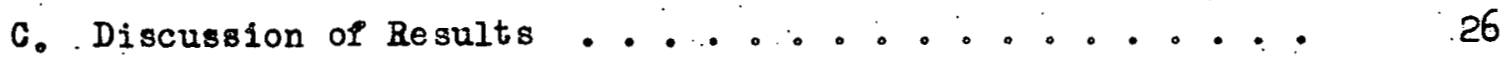

1. Venturi Atomizer ............... 26

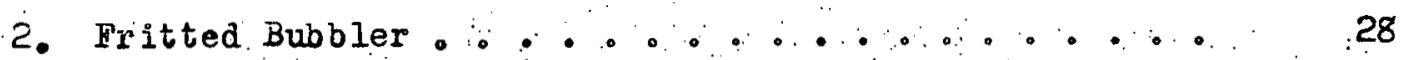

PART IV. REMOVAL OF NIPROGEN OXIDES FROM DIIUTE GASES

A. Removal Proceraer . . . . . . . . . . . . . 32

1. Absorption Combined with Chemical Reaction $\therefore 32$

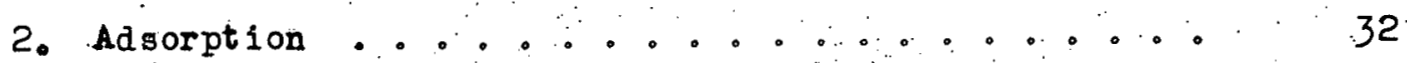

B. Experimental Equipment and Procedure $0_{0} \ldots \ldots \ldots$

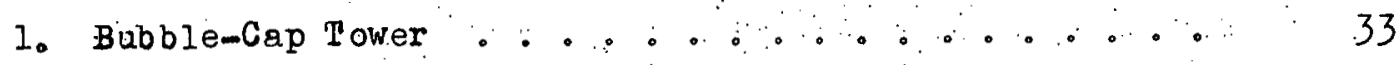

2. Packed Tower .................... 33

3. Spray Tower ..... $\ldots \ldots \ldots \ldots$

4. Fritted Bubbler ................ 33

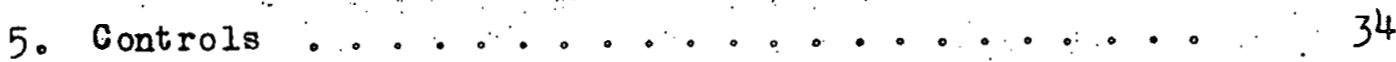

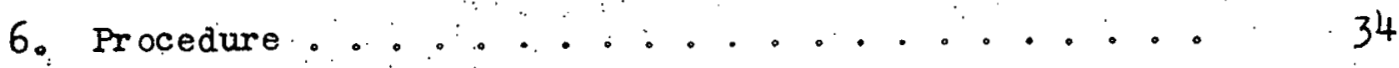

7. Cholce of Variables . . . . . . . . . . . 35

C. Discussion of Results .............. 36

1. Spray Tower . . . . . . . . 36

2. Packed Tower . . . . . . . . . . 39

3. Bubble-Cap Tower and Fritted Bubbler ....... 40

4. Silica-Gel Adsorber ............. . . . 42

5. Effects of Temperature and Pressure . . . . . . 42

D. Summary of Study on Removal of Nitrogen Oxides from Dilute Gases ................................... 44 
TABLE OF CONRENTS (Continued)

Page

PART $V_{i}$. EFTICIENCY OF AQUEOUS ABSORPTION OF NITROGEN OXIDES WITH . MUIPISTAGE BUBBLE-GAP COLUMN ......................... 45

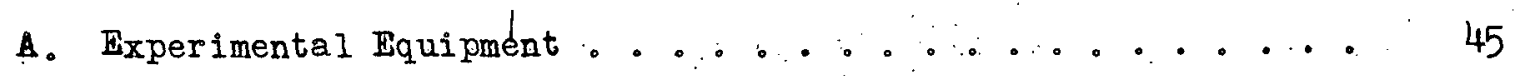

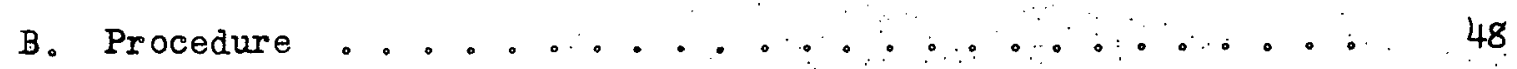

c. Discussion of Results . . . . . . . . . . . . . . . . 49

D. Summary of Results Obtained with Multistage Bubble-Cap Column 54

PART VI. CAUSTIC ABSORPTION OF NTTROGEN OXIDES FROM GASES $\because \cdots \cdots$

A. Experimental Apparatus and Procedure $\ldots \circ \cdots \cdots$

B. Discussion of Results . . . . . . . . . . 57

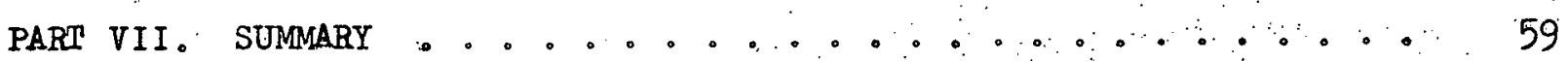

TABLE OF NOMENCLATURE . . . . . . . . . . . . . . 62

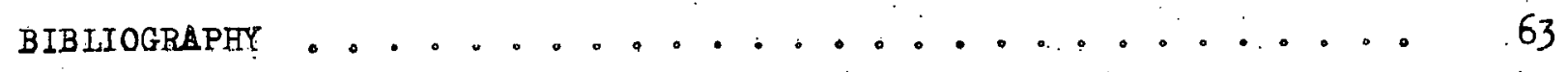

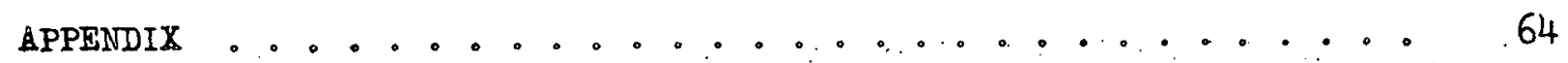

Semple Calculations . . . . . . . . . . . . 64

A. One-Plate Bubble-Cap Plate Column $\ldots \ldots \ldots . . . . . . . . . . .64$

1. Plate Efficiency and Concentrotion of $\mathrm{NO}_{2}$ and $\mathrm{N}_{2} \mathrm{O}_{4} \cdot{ } \cdot .64$

2. Sensitivity of Correlation of Integrated Rate Equation. 64

B. Wetted-Wall Absorption Unit $\therefore$. . .

6. Three-Plate Bubble-Cap Colunn . . . . . . . . 67

Tables of Experimental Data . . . . . . . . . 72

LIST OF FIGURES

Figure No.

1. Experimental Test for Validity of Integrated Rate Equation Assuming Process Controlied by Chemical Reaction Rates ........ 


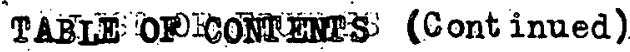

Page

Figure No.

2. Effect of $\mathrm{eNO}_{2}$ Concentration on Plate Efficiency $\ldots . . \cdots 7$

3. Experimental Equipment for Study on Vapor and Liquid Phase Reactions 15

4. Effect of Temperature on Removal Efficiency with Wetted-Wall Column 20

5. Refect of Gas Composition and Iiquid Injection Rate on Recovery Efficiency in Venturi Atomizer ................. . . . 27

6. Effect of Gas Concentration on Recovery Efficlency for FrittedGlass Disperser ......... . . . .........

7. EfPiciency of Nitrogen Dioxide Removal from Dilute Gas with Different Types of Equipment. . . ................. 38

8. Effect of Liquid Head and Gas Rate on Bemoval Efficiency. in Frittedalass Disperser . . . . . . . . . . . . . 41

9. Effect of Temperature. Pressure, and Cjcle Time on Removal Effi-.

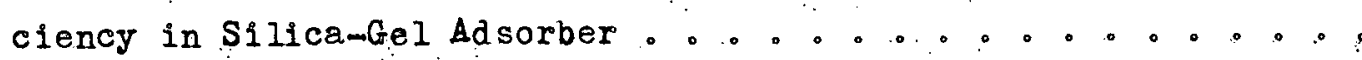

10. Experimental Equipment for Tests with Multistage Bubble-Cap Column 46

11. Effect of $\mathrm{eNO}_{2}$ Concentration in Entering Gases on Plate Ffficiency with Three-Plate Bubble-Cap Co'lumn and Medium Mist . . . ...

12. Effect of $\mathrm{eNO}_{2}$ Concentration in Entering Gases on Plate Efficlency with Three-Plate Bubble-Cap Column and No Observabole Mist . o. . . . 52

LISI OF TABIES

Table No.

1. Test Conditions Used for Determining the Efficlency of Nitrogen Dioxide Removal from Dilute Gases with Various Equipment 。.. 
PABIT OP CONPENS (Continued)

Table No.

Page

2. Experimental Data for One-Plate Bubble-Cap Column .......

72

3. Experimental Data Using Distilled. Water and Aqueous NaGI as Absor-

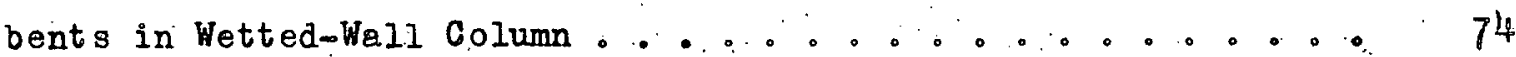

4. Experimental Data for Runs in Which Ext Gas from. Wetted-Wall Column was Analyzed .............................. 76

5. Experimental Data for Reoovery of Nitrogen Dioxido with Venturi

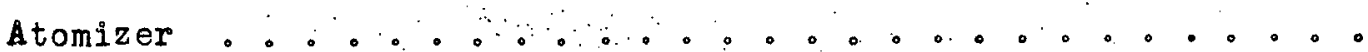

6. Experimental Date for Recovery of Nitrogen Dioxide with Fritted-: Glass Disperser . . . . . . . . . . . . . . 78

7. Experimental Data for Three-Plate Bubble-Gap Golumn with No Mist. 79

8. Experimental Data for Three-Plate Bubble-cap Column with Mist . . 81

9. Experimental Data for Caustic Absorption of Nitrogen Oxides . : 82 
PRINCIPLES AND PROGESSES FOR RGMOTING

NITROGEN OXIDES FHOM GASES

\author{
by \\ M. S. Peters \\ Engineering Experiment Station \\ University of Illinois \\ Urbana; IIlinois \\ August 31, 1955
}

\title{
ABSTRAGT
}

A study of the fundamental principles involved in the remoral of nitros gen oxides from gases was made, and experimental tests were conducted to develop improved methods for accomplishing the removal operation.

The important factor in determining the rate of rembral of nitrogen dioxide and dinitrogen tetroxide from gases was found to be the rate of the chemical reactions involved in the remoral process. The roles of gasophase and liquid-phase reactions, as well as mist formation, were investigated, and the results were interpreted on the basis of chemical reaction rates as the controlling mechanism.

The information from the fundamentel studies was applied to a study of improved methods for removing nitrogen oxides from gases. Experimental tests. were conducted with bubbleocap towers, packed towers, fritted bubblers'Venturi atomizers, wetted-wall towers, and spray. towers, Water, silica gel, and aqueous solutions of sodium hydroxide, sodium chloride, and nitric acid were examined as the removal media. Venturi atomizers were found to be very inefficlent for removing nitrogen oxides from gases, while fritted bubblers and silicaogel adsorbers were the most efficient of the various types of equipment tested. Information was obtained on approach, design data, and operating cono. ditions which can be used for developing new and improved methods for remoring nitrogen oxides from gases. 
PRINCIPLES AND PROCESSES FOR REMOVING

NITROGEN OXIDES FROM GASES

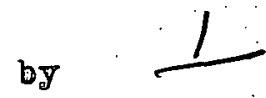

M.. S. Peters

\section{Engineering Experiment Station Jiniversity of IIIfnols \\ Urbana, Illinols}

Augast 31: 1955

\section{INTRODUCTION}

Many industrial processes evolve gases containing hitrogen oxides, and it is often necessary to effect removal or recovery of these oxides. In some cases, the gases must be cleaned before they can be released to the atmos. phere, while, in other eases, efficient recovery op the nitrogen oxides is a direct and essential part of the manufacturing process.

The purpose of the work reported herein was to obtain an understanding of the basic principles governing the removal of nitrogen oxides from gases and to develop improved methods for remoring the oxides. Since very little previous work has been done on the fundamental mechanisms and principles involved in the removal of nitrogen oxides from gases, the first investigations in this research program were directed toward a study of the basic factors. The results gave a definte indication of the controling mechanisms involved in the recovery process and showed the line of approach necessary to develop improved recovery methods. Part of the prelimfnary work has been described previously by Peters and co-workers (10, 11, 12). A review and extension of this investigation are presented in Parts I and II. of this report. 
Further work in this research program has dealt!l with removal of nitrogen oxides from gases using different types of equipment; such as packed towers, bubble-cap towers, spray towers, fritted bubblers, Venturi atomizers, and silicamgel adsorbers. The results of these tests are presented and inters preted in this report.

\section{A. Chemistry of the Aqueous Reactions of Nitrogen Oxides}

The important nitrogen oxides: in procegses involving requli ins with aqueous șolutions are $\mathrm{NO}_{2}$, $\mathrm{N}_{2} \mathrm{O}_{4}$. and No. Small amounte of $\mathrm{N}_{2} \mathrm{O}_{3} \mathrm{aut} \mathrm{Na}_{2} \mathrm{~N}_{5}$ are also present in the gases, but these compounds rapidly come to equilibrium with NO and $\mathrm{NO}_{2}$ and represent only a small fraction of the total oxides at room or higher temperatures (11, 12).

The essential chemical reactions occursing in the removal process

are

$$
\begin{aligned}
& \left.2 \mathrm{NO}_{2} \text { (Or } \mathrm{N}_{2} \mathrm{O}_{4}\right)+\mathrm{H}_{2} \mathrm{O} \longrightarrow \mathrm{HNO}_{3}+\mathrm{HNO}_{2} \\
& 2 \mathrm{HNO}_{2} \longrightarrow \mathrm{H}_{2} \mathrm{O}+\mathrm{NO}+\mathrm{NO}_{2}\left(\mathrm{Or} 1 / 2 \mathrm{~N}_{2} \mathrm{O}_{4}\right) \\
& \left.2 \mathrm{NO}+\mathrm{O}_{2} \longrightarrow 2 \mathrm{NO}_{2} \text { (Or } \mathrm{N}_{2} \mathrm{O}_{4}\right) \\
& 2 \mathrm{NO}_{2}=\mathrm{N}_{2} \mathrm{O}_{4}
\end{aligned}
$$

Reaction (D) attains equilibrium rapidiy and the equilibrium constant for this reaction is known as a function of temperature between $0^{\circ} \mathrm{C}$ and $90^{\circ} \mathrm{C}$. The oxio. dation of No proceeds relatively slowiy although the reaction goes essentially to completion. 
PARP I: CONPROLLING MECHANISM IN T HE AQUEOUS

\section{ABSORPTION OF NITROGEN OXIDES}

The results of a study on the controling mechanism in the aqueous absorption of nitrogen oxides have been reported in detall by Peters and coworkers (11, 12). A brief review of this work and an extension of the original data and approach are presented in this section.

The reactions involved in the removal of nitrogen oxides from gases by reaction with water are reversible and proceed at a finite rate. It is possible, therefore, that the rate of aqueous absorption is controlled by the rate of chemical reactions. On this basis, an analysis of the process was developed by the application of chemical kinetics. Simplification and integration of the basic rate equations gave the following results:

$$
\begin{aligned}
& -\left(\frac{\mathrm{dC}_{\mathrm{eNO}}}{\mathrm{dt}}\right)_{\text {net }}=\left(\frac{3 \mathrm{k}_{1}}{2}+\frac{3 \mathrm{k}_{3}}{4 \mathrm{~K}_{\mathrm{C}}}\right) \cdot\left(\mathrm{G}_{2} \mathrm{O}_{4}\right)\left(\mathrm{G}_{\mathrm{H}_{2} \mathrm{O}}\right)
\end{aligned}
$$

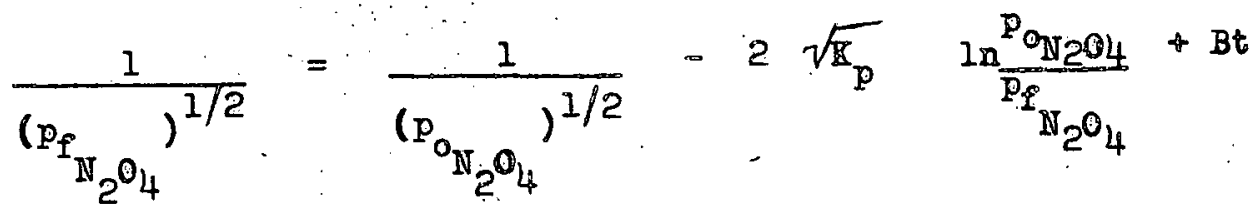

where $C=$ concentration, $g$ moles/ce

$$
\begin{aligned}
\mathrm{ONO}_{2} & =\mathrm{NO}_{2}+2 \mathrm{~N}_{2} \mathrm{O}_{4} \\
\mathrm{k}_{1} & =\text { rate constant for the reaction between } \mathrm{N}_{2} \mathrm{O}_{4} \text { and } \mathrm{H}_{2} \mathrm{O} \\
\mathrm{k}_{3} & =\text { rate constant for the reaction between } \mathrm{NO}_{2} \text { and } \mathrm{H}_{2} \mathrm{O}
\end{aligned}
$$

${ }_{\mathrm{P}_{2} \mathrm{O}_{4}}=$ final partial pressure of gaseous $\mathrm{N}_{2} \mathrm{O}_{4}$ atm

$$
\begin{aligned}
{ }^{\mathrm{P}_{\mathrm{O}}} \mathrm{N}_{2} \mathrm{O}_{4} & =\text { original partial pressure of gaseous } \mathrm{N}_{2} \mathrm{O}_{4}, \text { atm } \\
\mathrm{K}_{\mathrm{Q}} & =\text { equilibrium constant for the reaction } 2 \mathrm{NO}_{2}=\mathrm{N}_{2}^{\prime} \mathrm{O}_{4},(\mathrm{~g} \text { moles } / \mathrm{cc})^{-1} \\
\mathrm{~K}_{\mathrm{p}} & =\text { equilibrium constant for the reaction } 2 \mathrm{NO}_{2}=\mathrm{N}_{2} \mathrm{O}_{4}, \text { atm }-1
\end{aligned}
$$




$$
\begin{aligned}
& B=\text { a constant at any temperature } \\
& . t=\text { contact time, seconds }
\end{aligned}
$$

Equations (1) and (2) apply under the following conditions:

1. Rate of $\mathrm{eNO}_{2}$ removal is controlled by the rate of the chemical reactions.

2. Chemical reactions occur under irreversible conditions.

3. Constant temperature and constant gas rate preväil.

4. Instantaneous equiliurium exists between $\mathrm{NO}_{2}$ and $\mathrm{N}_{2} \mathrm{O}_{4}$.

5. Contact time is sufficiently short.so that there is no approoisolo oxidation of NO.

Experimentā. dāte were oblalned with a bubblcoap plate column under conditions of constant temperature, constant gas rate, irreversible react ions. negligible oxidation of No while gas was in contact with liquid, and essentially instanteneous equilibrium between $\mathrm{NO}_{2}$ and $\mathrm{N}_{2} \mathrm{O}_{4}$. A dense mist was observed in the gas phase in all the runs.

If the rate of $\mathrm{eNO}_{2}$ absorption is controlied by the rate of the chemical reactions, the experimental data should be correlated by Eq. (2), and a plot of $\left(1 / \mathrm{pq}_{\mathrm{N}_{2} \mathrm{O}_{4}}\right)^{1 / 2}$ versus $\left[\left(\mathrm{i} / \mathrm{p}_{\mathrm{N}_{2} \mathrm{O}_{4}}\right)^{1 / 2}-2 \sqrt{\mathrm{K}}\right.$ ln $\left.\left(\mathrm{p}_{\mathrm{N}_{2} \mathrm{O}_{4}} / \mathrm{Ps}_{\mathrm{N}_{2} \mathrm{O}_{4}}\right)\right]$ should be a straight line with a slope equal to 1.0." Figure 1 shows the excellent coro relation obtained between the experimental results and he pridcted realtio. This plot"covers"a 150 fold change in $\mathrm{N}_{2} \mathrm{O}_{4}$ concentration in the entering gases and gives strong support to the theory that the rates of the chemical reactions involving $\mathrm{N}_{2} \mathrm{O}_{4}$ and $\mathrm{NO}_{2}$ may control the rate of nitrogen oxides removal. The sensitivity of the correlation was checked by making calculations for conversions other than the reported values. It was found that the correlation was sensitive to changes in the experimental results, especially at high eNO $\mathrm{N}_{2}$ concentrations. 


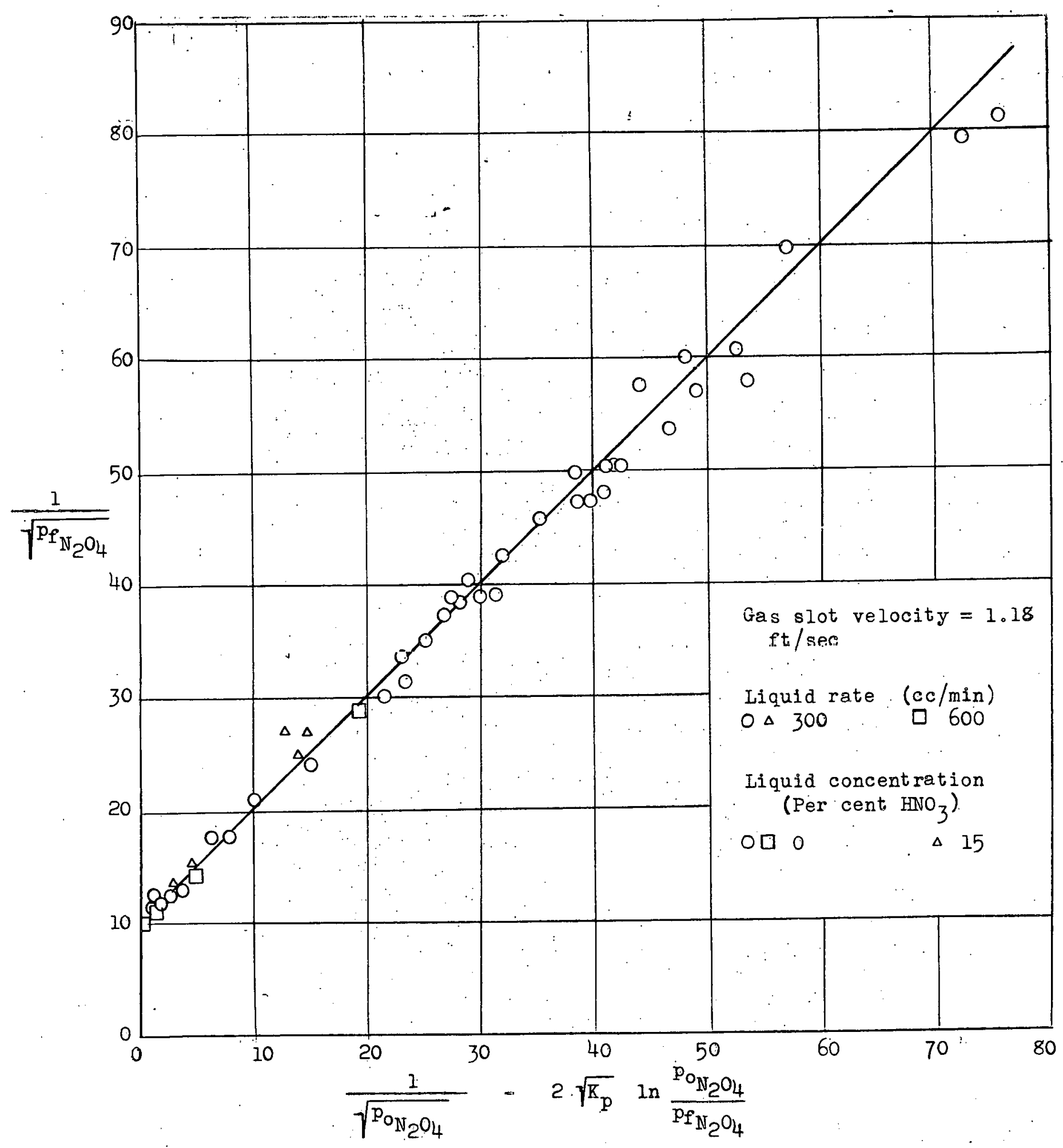

Figure 1. Experimental test for validity of integrated rate equation assuming process controlled by chemical reaction rates (Bubble-cap column. Mist present. $p=$ partial pressure. $K_{p}=8$ ) 
A plot similar to Figure 1 was presented in Technical Report Number 10 (Serial No. C0-1011) (11). The Figure now contains twice as many experimental points a.s before, and the range, of $\mathrm{N}_{2} \mathrm{O}_{4}$ concentration covered has been increased by a factor of six.

\section{A. Plate Bfficiency}

It is of interest to put the theoretical and experimental results on a, basis of plate efficiency. With this approach the practical significance of tho resnltis is immediately opparent. Plate effici ency is defined as the amount of nitrogen oxides removed from the gases divided by the amount of oxides which would have veen removed if the plate were theoretically perfect:

1. Chemical reaction rates as the controlling factor in the overoall mechanism. By choosing one experimental point as a basis, Eq. 2 can be used to predict the entire curve of plate efficiency versus $\mathrm{eNO}_{2}$ content of the entering gases. This has been done, and the theoretical curve is presented in Figure 2 for comparison with the experimental date. As shown in Figure 2, the experimental. plate efficiencies decrease with reduction in gaseous eNO concen- $^{-}$ tration. This result would be predicted for the case where the controlling mechanism is the rate of the chemical reactions.

2. Gaseous diffusion as the controlling factor in the over-all. mechanism. Chambers and Sherwood. (4) assumed the controlling fact or was the

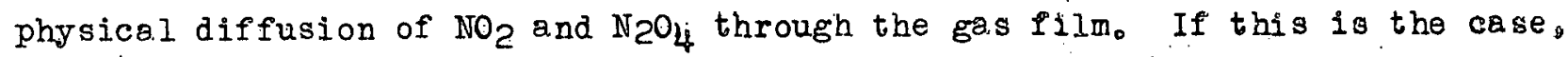
the following expression for the ebsorption rate should apply $(4,2)$ :

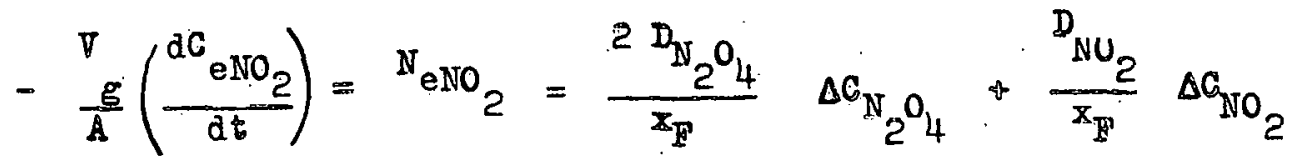

where $\nabla_{g}=$ volume of the bulk of the gas, ec

$$
A=\text { gas-liquid interfacial area, } \mathrm{cm}^{2}
$$




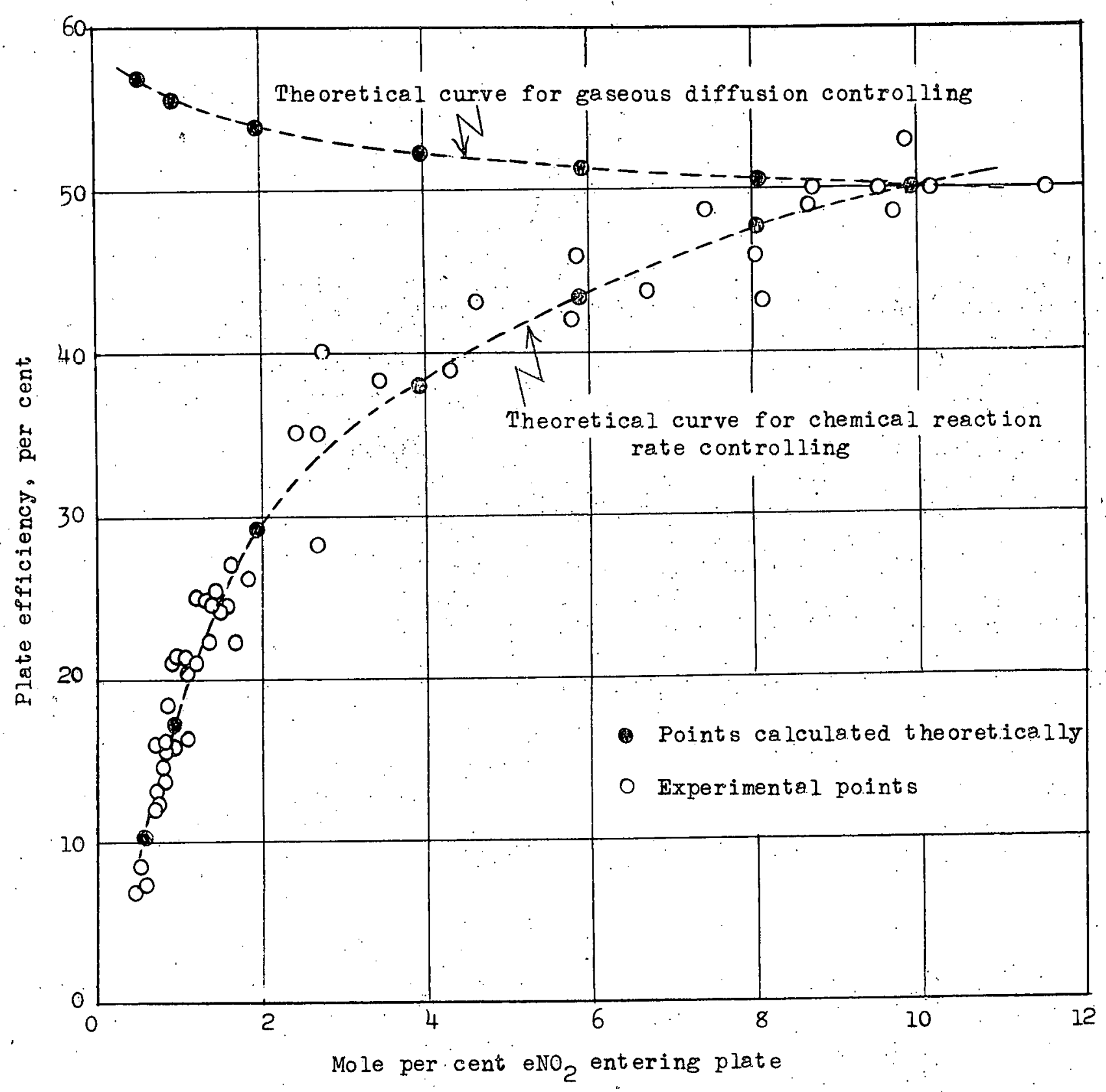

Figure 2. Effect of $\mathrm{eNO}_{2}$ concentration on plate efficiency (One-plate bubble-cap column at one atmosphere total pressure. Gas slot velocity $=1.18 \mathrm{ft} / \mathrm{sec}$. Mist present.) 


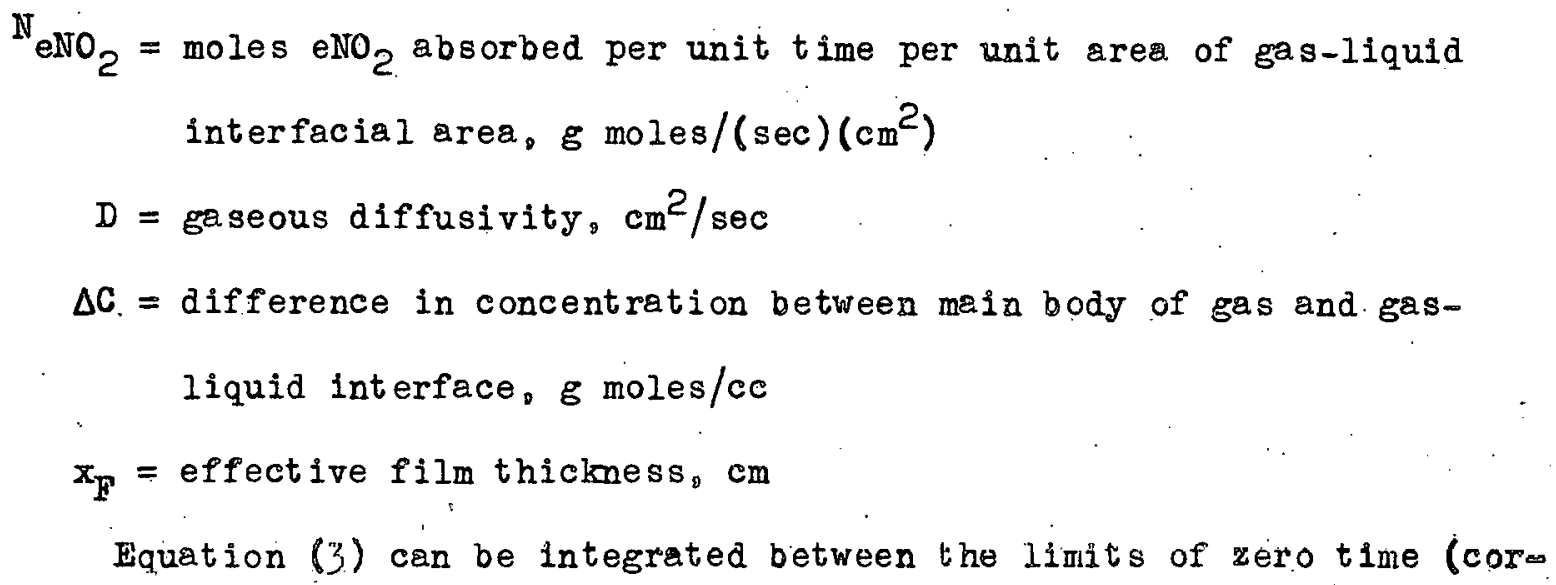
responding to an initial $\mathrm{N}_{2} \mathrm{O}_{4}$ concentration of $G_{\mathrm{ON}_{2} \mathrm{O}_{4}}$ ) and the ime (t) any portion of the gas is in contact with the liquid (corresponding to a final $\mathrm{N}_{2} \mathrm{O}_{4}$ concentration of $\mathrm{C}_{\mathrm{N}_{2} \mathrm{O}_{4}}$ ). Using the ratio $\mathrm{i}_{\mathrm{NO}_{2}} / \mathrm{y}_{2} \mathrm{~N}_{4}$ as $1_{0} 43$ (4) and assuming. the concentrations of $\mathrm{NO}_{2}$ and $\mathrm{N}_{2} \mathrm{O}_{4}$ to be zero at the gasoliquid interfacial region, the following result is obtained from the integration, with the concentration terms expressed in more-convenient units of partial pressure (9):

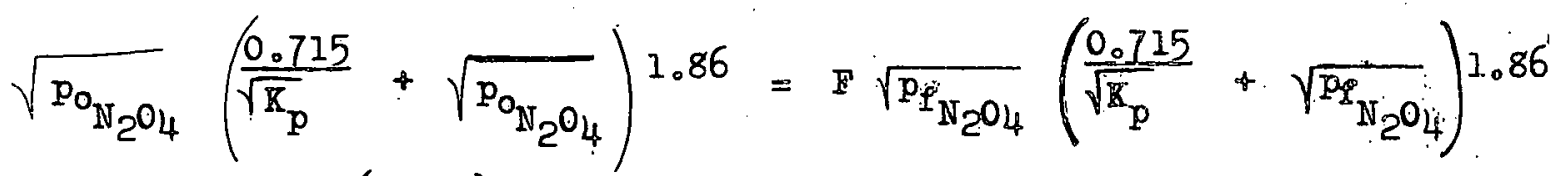
where in $F=\frac{A}{\nabla_{g}}\left(\frac{D_{\mathrm{N}_{2} \mathrm{O}_{4}}}{\mathrm{x}_{\mathrm{i}}}\right) 1.43 \mathrm{t}$.

Equation (4) should apply under the following conditions:

1. Rate of eNO2 absorption is controlled by gasecus difrusion.

2. Zero oxide concentration exists at gas-liquid interfacial region. (This would be essentially true if the reactions occurred irreversibly and gaseous diffusion were controlling)

3. Constant temperature and constant gas rate prepail.

4. Instantaneous equilibrium exists between $\mathrm{NO}_{2}$ and $\mathrm{N}_{2} \mathrm{O}_{4}$.

5. Contact time is sufficiently short so that there is no appreciable oxio dation of NO. 
Equation (4) can be used to predict a theoretical curve of plate efficiency versus $\mathrm{eNO}_{2}$ concentration in the entering gases if one experimental point is chosen as a basis. The theoretical curve is presented in Figure 2, where it can be seen that the experimental points do not follow the curve predicted for the conditions existing if gaseous diffusion were controlling. Instead, the experimental points follow the curve predicted for the conditions existing if chemical reaction rates were controlling, In general, if operating cono ditions can be obtained which tend to eliminate chemical reaction rates as the controlling factor, the upper limit on the plate efficiency would be represented by the diffusion-controlling curve in Figure?. 


\section{PARP II, VAPOR AND LIQUID PHASE BEACTIONS BETWEEN}

\section{NITROGEN DIOXIDE AND WATER}

It has generally been assumed in the past that the reactions between nitrogen dioxide and water occur by a mechanism in which gaseous nitrogen dioxide diffuses into the liquid phase where the chemical reactions take place. Chambers and Sherwood (4) have proposed that a gasmphase reoction may occur, and recent investigations (11, 12) indicote the gas phase reaction may be of considerable importance in the reaction mechanism。

To develop efficient equipment for squeous absorption of nitrogen dioxide, it is necessary to hiow lf the 1mporlant reactions occur in the ges phase or in the liquid phese. Therefore, this part of the research program on nitrogen oxides was undertaken to determine in which phose the chemical reactions take place.

\section{A. Theory}

The information summarized in Part I indicates that the rate of aqueous absorption of nitrogen dioxide is controlled by the rate of the chemical reactions, rather than by diffusion. By the use of chemical kinetics, therefore, it is possible to predict the manner in which the concentrations of the reactants affect the rate of nitrogen dioxide absorption.

The chemical reactions of importance may be expressed as follows:

$$
\begin{aligned}
& \mathrm{N}_{2} \mathrm{O}_{4}+\mathrm{H}_{2} \mathrm{O} \underset{\mathrm{k}_{2}}{\stackrel{\mathrm{k}_{1}}{\rightleftarrows}} \mathrm{HNO}_{2}+\mathrm{HNO}_{3} \\
& 2 \mathrm{NO}_{2}+\mathrm{H}_{2} \mathrm{O} \underset{\mathrm{K}_{4}}{\stackrel{\mathrm{k}_{3}}{\rightleftarrows}} \mathrm{HNO}_{2}+\mathrm{HNO}_{3}
\end{aligned}
$$




$$
\begin{aligned}
& 2 \mathrm{HNO}_{2} \underset{\mathrm{k}_{6}}{\stackrel{\mathrm{k}_{5}}{\rightleftarrows}} \mathrm{NO}+1 / 2 \mathrm{~N}_{2} \mathrm{O}_{4}+\mathrm{H}_{2} \mathrm{O} \\
& 2 \mathrm{HNO}_{2} \underset{\mathrm{k}_{8}}{\stackrel{\mathrm{k}_{7}}{\rightleftarrows}} \mathrm{NO}+\mathrm{NO}_{2}+\mathrm{H}_{2} \mathrm{O} \\
& 2 \mathrm{NO}_{2}=\mathrm{N}_{2} \mathrm{O}_{4} \text { (Instantaneous equilibrium) }
\end{aligned}
$$

The $\mathrm{k}^{0} \mathrm{~s}$ represent the reaction rate constants for the forward and reverse reactions. Reactions (a), (b), and (e) occur simultaneously, while Reactions. (c) and (d) are consecutive to reactions (a) and (b). The oxidation of No to yleld $\mathrm{NO}_{2}$ and $\mathrm{N}_{2} \mathrm{O}_{4}$ proceeds a relativels slow rate." This reaction is not included here because experimental tests with the wetted-wail column used in this investigation indicated that the rate of No oxidation was too slow to have any appreciable effect on the results.

If the absorbing fluid is water or dilute nitric acid, the oyera.11 reactions are essentially frreversible and the following relationship. presented in Part I, applies:

$$
-\left(\frac{{ }^{d C_{2}}}{d t}\right)_{\text {net }}=\left(\frac{3 k_{1}}{2}+\frac{3 k_{3}}{4 \mathrm{~K}_{\mathrm{C}}}\right)\left(\mathrm{C}_{\mathrm{N}_{2} \mathrm{O}_{4}}\right)\left(\mathrm{C}_{\mathrm{H}_{2} \mathrm{O}}\right)
$$

At any fixed temperature and liquid composition, the first and last terms on the rightchand side of $\mathrm{Eq}$. (1) are constant, and the absorption rate should be directly proportional to the $\mathrm{N}_{2} \mathrm{O}_{4}$ cancentration. In agreem ment with Eq. (1), Denbigh and Prince (5), Caudle and Denbigh (3), and Peters, Ross and Andersen (11, 12) found the absorption rate to be directly proportional to the gaseous concentration of $\mathrm{N}_{2} \mathrm{O}_{4}$ when the absorbing fluid was water or dilute nitric acid and a bubble-cap plate column with mist present or a wetted-wall absorption unit was employed. Caudle and Denbigh have also found that the absorption rate is independent of the bulk liquid 
volume or bulk gas volume and is directly proportional to the interfacial area between the gas and the liquid. Therefore, the controlling chemical reactions must take place in the region of contact between the gas and liquid phases. The region in which the major part of the gasophase reaction occurs may be designated as the gas film while that in which the liquid-phase reaction occurs is designated as the liquid film.

If the reactions occur in the gas film, the water coneentiation in Eq. (1) is proportional to the water-vapor fuffacity and ingreasea with temperature. Therefore, the term.involving $\mathrm{k}_{1} ; \mathrm{k}_{3}$, and $\mathrm{k}_{\mathrm{G}}$ is Eq. (I) can be evaluated as a function of tempereture from experimental and physical data giving the variation of absorption rate, $\mathbb{N}_{2} \mathrm{O}_{4}$ concentration, and water concentration with temperature.

If the rate of equivalent nitrogen diaxide absorption into pure water is determined experimentally, it should be possible to predict the rate of absorption for a different water-vapor fugacity if the other variables, such as temperature and contact time, are held constane. If the majur rea actions occur in the gas film, the rate predicted with the changed water - apox fugacity should agree with experimental rates obtained at the new water-vapor fugacity. However, if an appreciable portion of the reaction ocers ix the liquid film and a non-ideal solution is used to give the new fugacity. it is very unlikely that the predicted rates will agree with the experimentally observed rates. The reason for the deviation is that the components of the nonideal liquid solution would probably act as catalysts or inbibitors for the chemical reactions, causing a change in the value of the term involving the reaction rate constants in $\mathrm{Eq} .(1)$.: 
Under conditions in which the partial pressure of equivalent nitrogen dioxide is low, perfect-gas deviations are small, and little error is introduced by assuming the fugacity of the water vapor to be equivalent to the water-vapor pressure. In the experimental work reported here, the maximum partia.I pressure of equivalent nitrogen oxide is 0.05 atm, and the use of water-vapor partial pressure in place of fugacity is acceptable.

A second experimental test for the occurrence of a gas-phase reaction can be made by including in the liquid phase a material which would react with the nitrous acid formed in Reactions (a) and (b) or with any equivalent nitrogen dioxide that entered the liquid. Under these conditions, no NO would be evolved if all the chemical reactions occur only in the liquid phase, and an analysis of the gases leaving the unit should show an absence of No.

Sodum hydroxide reacts with equivalent nitrogen dioxide and nitrous acid as follows:

$$
\begin{aligned}
& 2 \mathrm{NaOH}+2 \mathrm{NO}_{2}\left(\text { or } \mathrm{N}_{2} \mathrm{O}_{4}\right) \longrightarrow \mathrm{NaNO}_{2}+\mathrm{NaNO}_{3}+\mathrm{H}_{2} \mathrm{O} \\
& \mathrm{NaOH}+\mathrm{HNO}_{2} \longrightarrow \mathrm{NaNO}_{2}+\mathrm{H}_{2} \mathrm{O}
\end{aligned}
$$

The combined effect of these two reactions should be sufficient to keep any NO from being formed (4). Therefore, if an aqueous solution of sodium hym droxide is used to absorb gaseous nitrogen dioxide, the presence of NO in the exit gases would indicate the occurrence of a gas-phase reaction. Caudle and Denbigh (3) and Chambers and Sherwood (4) have made tests of this type using wetted-wall columns, and their results are di rectly contradictory。 Caudle and Denbigh reported no No in the exit gases while Chambers and Sherwood found an appreciable amount of this compound in their exit gases. 


\section{B. Experimental Equipment}

A diagram of the experimental equipment is shown in Figure 3. wetted-wall Pyrex column having a length of $100 \mathrm{~cm}$ and an inside diameter of $2.15 \mathrm{~cm}$ was used for the absorption operation. A Pyrex tube $5.0^{\circ} \mathrm{cm}$ in diameter was placed concentrically around the column and was wrapped with a heating ribbon to permit regulation of the column temperature. A third Pyrex trabe $6.0 \mathrm{~cm}$ in diameter was placed concentrically around the tubes to insulate' the system.

The feed. liquid passed from a constantmead tank through a $1 / 4$ inch stainlessasteel needle valve and a rotameter to a 500 ml feed bulo at the. upper portion of the column. A liquid seal was formed in the bulb by sealing a...section of. Pyrex tubing to the bulb so that it overlapped and was concentric. with the column. A. sample tap was located between the feed tank and the rotameter to permit analysis of the feed liquid. A heating element was placed between the rotameter and feed bulb to permit regulation of the feed-liquid temperature. Although the rotameter was calibrated with water, it was used only to give reasonably accurate flow settings, and the exact flow rate was determined by timed rolumetric measurements。

Gaseous nitrogen dioxide; obtained from Matheson Company, Ince of 98 per cent purity, was mixed with filtered and dried air or nitrogen as a diluent. The mixture was sampled and edmitted to the bottom of the column through a Pyrex tube of $1.58 \mathrm{~cm}$ out side dianeter sealed into a 400-mi liquides exit bulb. The exit bulb was insulated with 85 per cent magnesia to ensure accurate temperature measurement of the exit liquid. Iiquid seal was formed by the overlapping of the entering-gas tube with the column. The height of the 


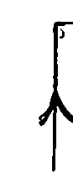

Iiquid

supply
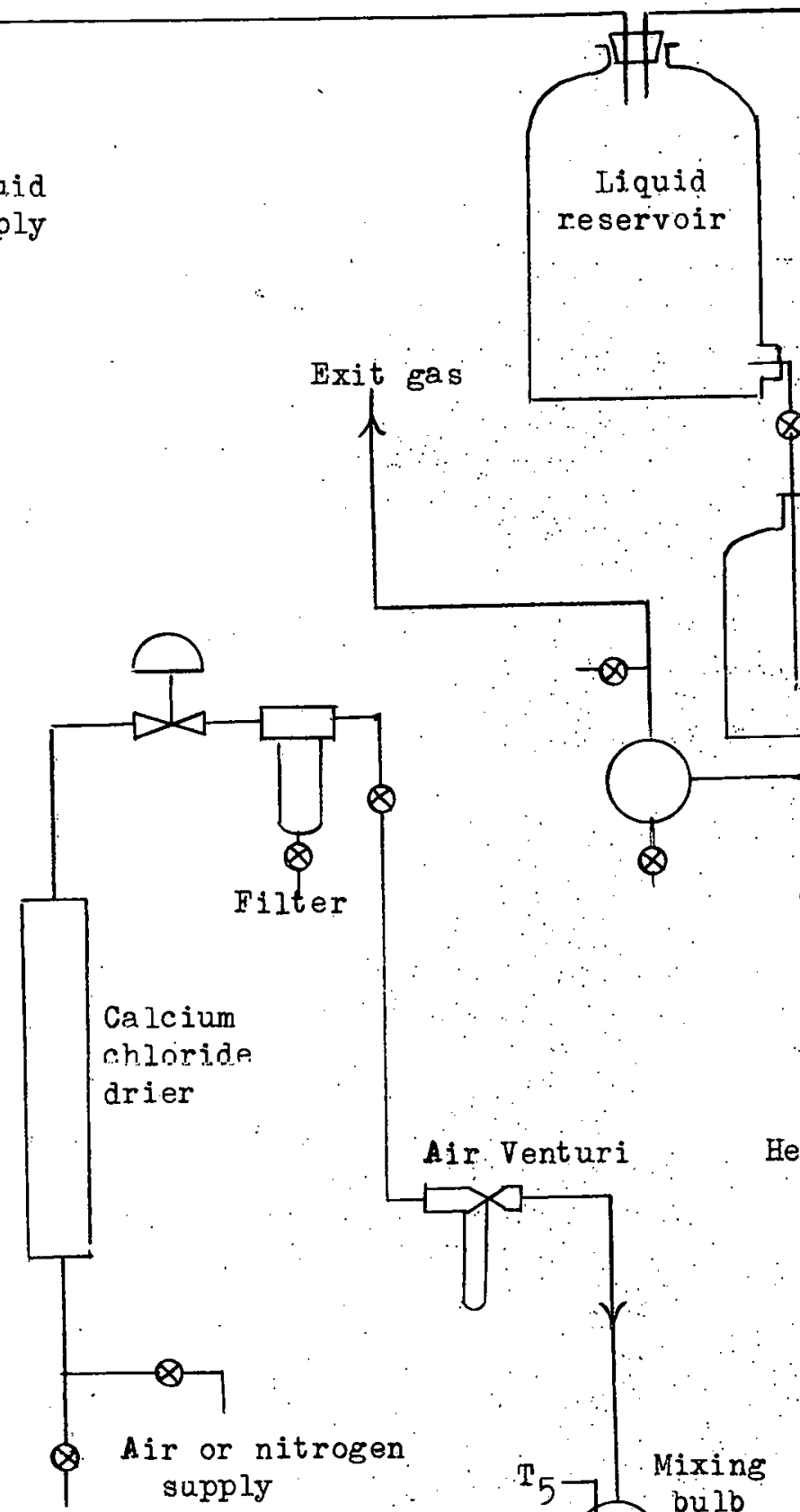

Air Venturi
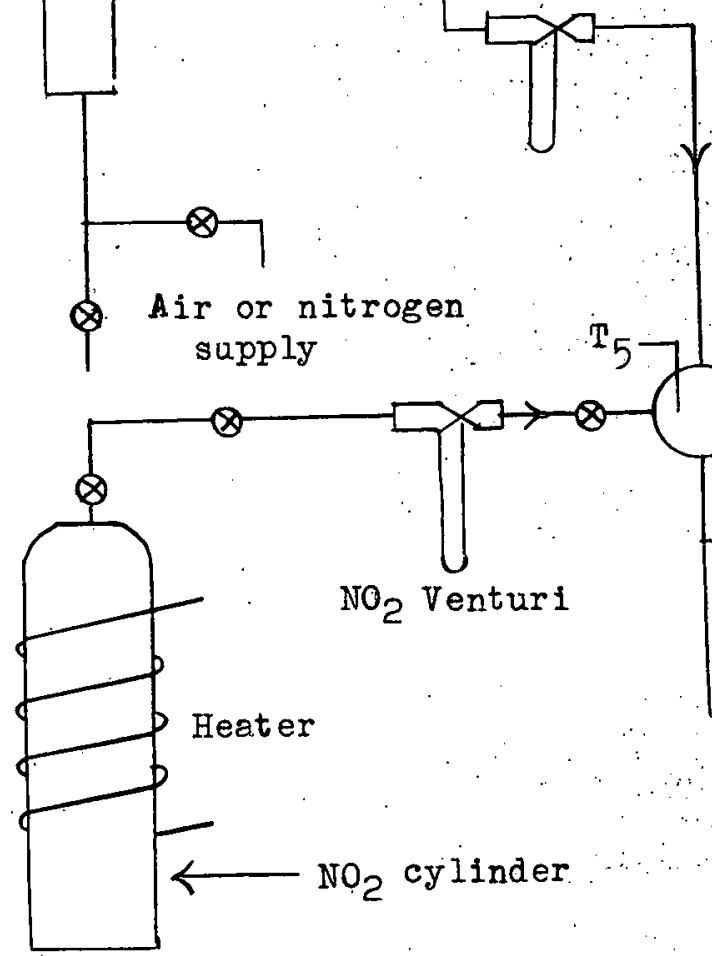

Ming

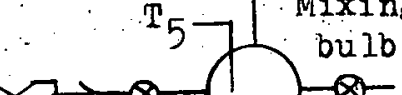

$-8$

$\mathrm{NO}_{2}$ Venturi

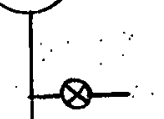

Constant-head tank

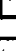

7

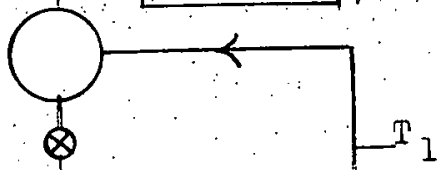

$\mathrm{T}_{1}$

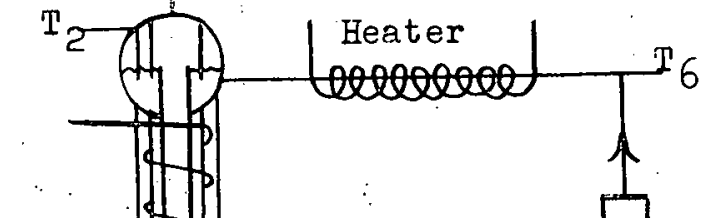

$T_{6}$

$$
T_{3}
$$
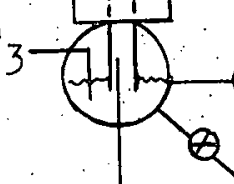

Liquid flow

rotameter

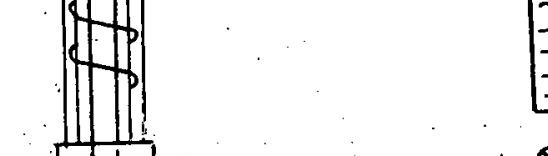


seal was controlled by a, 1/4-inch stainless-steel globe valve which was used to regulate the exit-liquid flow rate. The exit gases passed through an entrainment bulb, past $a$ sample tap, and were exhausted through $a$ hood. The air or nitrogen flow rate was measured by a calibrated Venturi meter, and the approximate flow rate of the nitrogen dioxide was set with the aid of a second, calibrated Venturi meter. The exact amount of nitrogen dioxide entering the unit was determined from the diluent flow rate and an analysis of the entering gas mixture.

Temperatures at the following points were measured by iron-constantan thermocouples: (1) gas leaving the column, (2) liquid entering the column; (3) liquid leaving the column. (4) gas entering the column, (5) gas mixing bulb, and (6) liquid leaving the rotameter.

\section{Procedure}

All runs were made at a liquid flow rate of approximately $210 \mathrm{cc}$ per minute. The absorbing media used were distilled water, 20 weight per cent aqueous sodium hydroxide solution, and 24 weight per cent aqueous sodium chloride solution. The same flow rate of equivalent nitrogen dioxide (evo ${ }_{2}=$ $\mathrm{NO}_{2}+2 \mathrm{~N}_{2} \mathrm{O}_{4}$ ) was used in all runs. The diluent flow rate was 0.0775 pounds per minute with the entering gos mixture containing 4.8 mole per cent eNU 2 。 All runs were made at atmospheric pressure and at temperatures ranging from $83^{\circ} \mathrm{F}$ to $132^{\circ} \mathrm{F}$. Since liquid and gas flow rates were maintained constant for all the experimental tests, hydrodynamic effects, such as variation in velocity distribution or liquid-surface rippling, were as sumed to be essentially con stant for all runs. For normal operation in a wettedowall colimn, these effects would be relatively unimportant, and the comperison technique used in 
this work would make them even less important.

Nitrogen was used as the diluent in seven of the twenty-two runs in which distilled water was. used as the absorbing fluid and in all the runs where sodium hydroxide solution was the absorbing fluid. Air was used as the diluent in the remaining distilled-water runs and in a.ll the runs where sodium chloride solution was the absorbing fluid. If the oxygen in the air diluent had oxidized an appreciable fraction of the

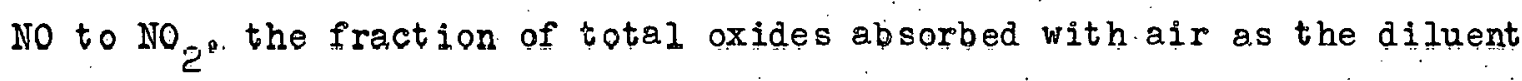
would be greater than when nitrogen was the diluent. Eowever, in the distilled-water runs, no significant difference in results was found between the two diluents, indicating that the gaseous hold-up time in the column was not sufficient to permit any appreciable axidation of NO.

In the actual operation of the equipment, the diluent flow rate and liquid flow rate were set initially: the column was completely wetted, and the liquid seal in the exit bulb. was adjusted by means of the exit-liquid control valve. Blank samples of the entering diluent and leaving liquid were taken. The nitrogen dioxide was then admitted at the desired flow rate, and the temperatures of the entering liquid, leaving liquid, and entering gas mixture were adjusted to the desired value by means of heating elements. These three temperatures were held within a $5^{\circ} \mathrm{F}$ range for every run. After the desired temperature was reached and equilibrium was attained, the liquid flow rate was determined by measuring the time necessary to collect a known volume of the liquid. All temperatures were recorded and gas samples and product-liquid samples were taken.

The entering-gas samples were taken in evacuated 200-ml glass 
bulbs containing hydrogen peroxide. The bulbs were fitted with selfmsealing rubber stoppers, and hypodermic needles were used both to evacuate the bulbs and to admit the gas samples. The amount of nitric geid formed by the action of hydrogen peroxide on nitrogen dioxide was determined by titrating the contents of the sample bulb with standard sodium hydroxide. From the weight of the gas sample and the amount of nitric acid formed, it was possibile to. determine the $\mathrm{eNO}_{2}$ content of the entering gas.

Samples of the exit gas were taken for all the runs in which sodium hydroxide solution was used as the absorbent and in several check runs when distilled water was the absorbent. Since the exit gases containod No in addition to $\mathrm{NO}_{2}$ and $\mathrm{N}_{2} \mathrm{O}_{4}$, it was necessary to take two samples of the exit gas to obtain a complete analysis. One sample was taken in a bulb containing hydrogen peroxide. while another sample was taken in a bulb containing potassium permanganate. The amount of potassium permanganate consumed in the reactions with NO and $\mathrm{eNO}_{2}$ was determined by back titrating with sodium thiosulfate. The results of the two analyses were used to calculate the amounts of $\mathrm{NO}$ and $\mathrm{eNO}_{2}$ in the exit gas.

The exit liquid, with the exception of the runs with sodium hydroxide solution, was analyzed for acid content by titrating a. known volume of the liquid with standard sodium hydraxide. The removal efficiency, which is . defined as the per cent of the entering oxides removed from the gases, was determined for each run. For the runs with distilled water and sodium chloride solution as the absorbing media, the removal efficiency was determined from the analysis of the entering gas, analysis"of the exit liquid, and flow rates of the entering gas and exit liquid. In the runs with aqueous sodium hydroxide 
as the absorbent, an accurate analysis of the exit liquid could not be obtained, and the removal efficiency was calculated from the analyses of the entering and leaving gas streams. To check the accuracy of this method for determining removal efficiency, several runs were made with dist lled water as the absorbent, and the removal effici ency was calculated on the basis of the exitaliquid analysis and also on the basis of the exit-gas analysis. Good agreement $( \pm 2 \%$ ) was found between the two methods if the unit was operated under conditions in which no mist was formed. It was found that mist formed only if unfiltered alr containing oll nuclei was used. Therem fore, all tests were carried out using filtered and dried diluent, and no mist was observed in any of the reported runs.

\section{Discussion of Results.}

The important experimental results are presented in Figure 4. The removal efficiency, plotted as the ordinate, is the per cent of the entering $\mathrm{eNO}_{2}$ removed from the entering gas. The arithmetic mean of the temperatures of the entering iiquid, exit liquid, ent ering gas, and exit gas is plotted as the abscissa.

It can be seen that the removal efficiency decreased significant ly over the temperature range investigated $\left(83-132^{\circ} \mathrm{F}\right)$. When distilled water or 24 per cent sodium chloride solution wes used as the absorbing liquid, the efficiency at $130^{\circ} \mathrm{F}$ was approximately $45-50$ per cent of that obtained at $85^{\circ} \mathrm{F}$. While the rate of decrease was even more rapid when 20 per cent sodium hydroxide solution was the absorbent.

As indicated in the theoretical discussion, the term involving the reaction rate constants in $E q$. (I) should be constant at constant 


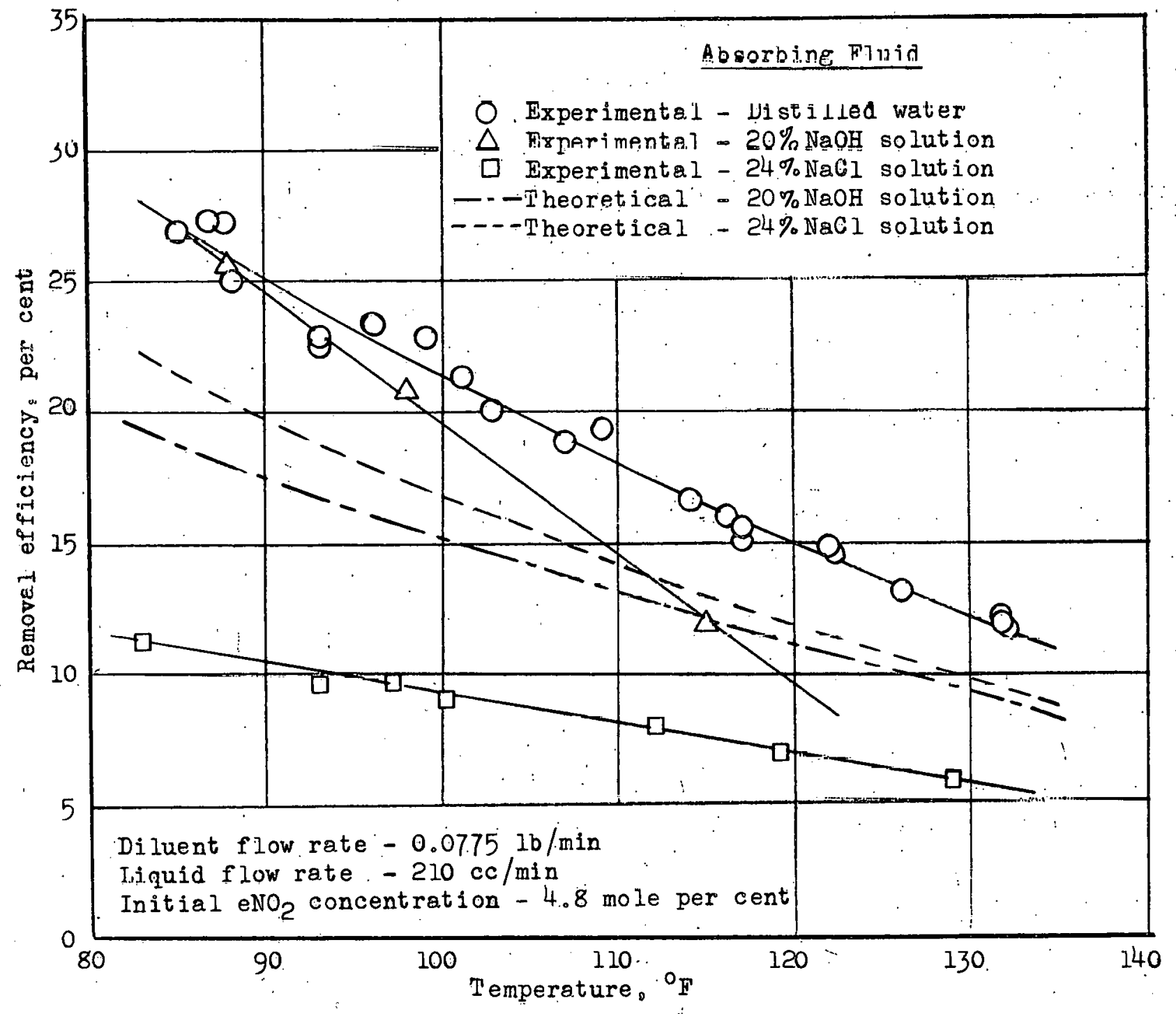

Figure 4. Effect of temperature on removal, efficiency with wetted-wall column 
temperature if the reactions occur completely in the gas phase. Therefore, the rate of removal and the removal efficiency should be proportional to the water-vapor fugacity at any constant values of temperature, gas rate, and gaseous $\mathrm{eNO}_{2}$ concentration. If the removal efficiency is known at one temperature and one water-vapor fugacity, it is possible to: predict the removal efficiency at a different water-vapor fugacity with all other variables held constant, assuming the reactions occur completely in the gas phase or gas filmo

By integrating $\mathrm{Eq}$. (1), the removal efficiencies for 24 per cent sodium chloride absorbent and 20 per cent sodium hydroxide absorbent were predicted at various temperatures on the basis of the experimental results obtained with distilled water as the absorbent. Standard vapor-pressure data for aqueous solutions of sodi um chloride and sodium hydroxide were used. In carrying out these calculations, it wa necessary to use the equilibrium constant for the dimerization of $\mathrm{NO}_{2}$ to $\mathrm{N}_{2} \mathrm{O}_{4}(14)$, and it was found that the ratio of the efficiencies at any given temperature was practically the same as the ratio of the water-vapor pressures.

The predicted efficiency curves are shown in Figure 4, and it can be seen that there are wide deviations between the experimental curves and the theor etical curves. Assuming the rate proportionalities as expressed by Eq. (1) are correct, the deviations between the predicted and experimental curves can only be explained by a change in the rate constants involved. This could be expectidto occur if at least part of the reactions occurred in the liquid phase where the reactive ions could serve to catalyze or inhibit the reactions. 
In the runs with 20 per cent sodium hydroxide solution as the absorbent, the exit gas was analyzed, and No was found in every case. The presence of NO in the exit gas indicates the occurrence of a gas-phase reaction, since this compound would not have been formed if the reactions occurred completely in the liquid phase.

Because relatively small amounts of No were present in the exit gas, it was very difficult to determine the exact amount of Nu with high accuracy. On the basis of total material balances, it was possible to culculate the amount of No which would have been formed if no sodium nitrite was formed in the liquid. For the various rung with sodium hydroxide, it was found that the exit gases contained from 16 to over 100 per cent of the total No which theoretically could have been formed. These analyses were obviously not precise because of the difficulty of analyzing the small amount of No present, but thề do indicate definitely the presence of No and give a qualitative indication of the amount of the reaction which occurred in the gas phase。

In all runs, it was found that the temperature of the gas increased as it passed through the tower. The temperatures of the inlet gas, inlet liquid, and exit liquid were all maintalned essentially constant at the same temperature throughout each run. However, the exitogas temperature was always greater than the inlet-gas temperature with the femperature rise varying from $1^{\circ} \mathrm{F}$ to $11^{\circ} \mathrm{F}$ for the different rugs. The temperature increase was greater in the low-temperature runs than in the high-temperature runs. Ihis increase in gas temperature was probably caused by the occurrence of the exothermic gaso phase reaction between nitrogen dioxide and water。 
E. Summary of Study on Vapor and Liquid Phase Reactions

The results of this study indicate that both gas-phase and liquidphase reactions occur in the removal of nitrogen dioxide from gases by contact with aqueous solutions. The major part of these reactions does not occur in the bulk phases but takes place in the gas film or liquid film at the boundaries between the two phases.

The presence of No in the exit gases when sodium hydroxide solution is used as the absorbent indicates the existence of a gas-phase reaction, and the observed increase in gas temperature in the absorption column is consistent with a gas-phase reaction. On the basis of chemical kinetics, an equation for the rate of nitrogen dioxide absorption can be developed which has been shown to be applicable when the reactions occur under irreversible conditions. According to this equation, if all variables except the water-vapor fugacity are held constant, the rate of removal of gaseous nitrogen oxides. should be directly proportional to the water-vapor fugacity as long as the reactions occur completely in the gas phase. How ever, if a liquid phase reaction occurs, the proportionality between the oxide removal rate and the water-vapor fugacity would not be expected to apply because the material in the liquid phase cousing the change in the water-vapor fugacity would probably inhibit or catalyze the rate of the liquid-phase reactions. The occurrence of a liquid-phase reaction is indicated by the fact that the rate of removal of nitrogen oxides from a dilute gaseous mixture is not directly proportional to the partial pressure (or fugacity) of the water vapor at constant conditions of temperature, gas rate, and gas composition. 


\section{PABT III. DISPERSION BY VENTURI ATOMIZER AND FRITTED}

\section{BUBBIER FOR NITROGEN OXIDES ABSORPTION}

The results presented in Parts I and II of this report show that two factors are of major importance in the development of improved methods for removing nitrogen oxides from gases: (1). It is desirable to supply the maximum amount of gas-liquid contact area: and (2) Since the rates of the. chemical reactions may control the rate of nitrogen oxides removal, a reasonably long time of contact between gas and liquid should be maintained.

A Venturi atomizer can be used to obtain Pine dispersion of a liquid in a gas, thereby supplying a large amount of gasoliquid contact area. The same result can be obtained by use of a fritted bubbler giving dispersal of a gas in a liquid. Although the effective gasoliquid contact time in a Venturi atomizer is relatively. short, the beneficial effects of the large contact area might be able to orercome the detrimental effects of the short contact time. This study was carried out to determine the characteristics of Venturi atomizers and fritted bubblers for removing nitrogen oxides trrom gāses.

\section{A. Ripeximental Equipment}

1. Venturi atomizer. A Jucite Venturi with a throat diameter of $1 / 4 \mathrm{in}$. and a throat length of $1 / 2 \mathrm{in}$. was used. The gas velocity was 300. ft/sec in the Venturi throat. Gas flow. rates were measured upstream from the liquid-injection Venturi by a standard Ventur $j$ meter. Nitrogen dioxide was injected sufficiently far upstream to ensure a uniform composition at the gas analysis point. Liquid was injected azially with a single stainless-steol hypodermic needle which had an inside diameter of 0.051 in. Samples of the 
spray were collected with an impact tube at $0.25,0.50$, and 1.00 in. from the point of liquid injection.

2. Fritted bubbler. The fritted-glass disperser was a relatively simple apparatus. The contacting element was a standard coarse-porosity Pyrex fritted-glass cylinder. The dimen sions of the cyinder were $4 \mathrm{~mm}$ $I_{0} \mathrm{D}_{\circ}, 12 \mathrm{~mm} 0 . \mathrm{D}_{\circ}$, and $19 \mathrm{~mm}$ high. The base of the cylinder was sealed and gas passed only through the sides. The cylinder was located at the bottom of a liquid-filled column 43 in high and $2-3 / 8$ in. in diameter. The gas passed through the interstices in the fritted glass:and bubbled up through two liters of liquid. The gas then passed to a column filled with standard sodium hydroxide and hydrogen peroxide for removal of any nitrogen dioxide not absorbed in the first column.

\section{B. Analytical Procedure}

The gas phase in the Venturi atomizer was analyzed for nitrogen dioxide by passing a sample through a standard solution of sodium hydroxide containing hydrogen peroxide and measuring the remaining gas in the sample with a wet-test meter. All the nitrogen dioxide was absorbed in the sodium hydroxide, and the excess hydroxide was determined by titration with stindard hydrochloric acid. Total acid concentration in the liquid phase was determined by titration with standard sodium hydroxide. Nitrous acid content in the liquid phase was found by addition of an excess of potassium permanganate followed by back titration with standard sodium thiosulfate. Simflar procedures were used with the fritted bubbler. 


\section{Discussion of Results}

1. Venturi atomizer. Previous investiggtions with Venturi atomizers (1. 2. 11) have shown high initial mass-transfer coefficients for oxygen absorption by pure water. These high massetransfer coeficients can be attributed: to the large initial interfacial area, high relative gasoliquid velocity, and great liquid turbulence. The mass-transfer coefficients decrease rapidy with increase in distance from the point of liquid injection: The decrease in mass-transfer cofficients is caused oy reduction in interfactal area as the dispersed films and filaments shatter into spherical droplets; by decrease in the relative velocity as the droplets are acceleratod to the gas velncity: and by the reduction in liquid turbulence as the droplets pass downstream.

The characteristics of the dispersed liquid in a Venturi atomizer should permit rapid rates of nitrogen dioxide absorption in the atomization zone. Under the se conditions, the major chemical reactions could occur in the liquid phase, and the high rate of oxygen absorption could permit rapid oxidation of No in the liquid phase. Experimental tests indicate that some of the absorbed oxygen does enter into the oxidation reaction, but the oxidation reaction does not control the rate of absorption of nitrogen dioxide.

The removal fficiency for nitrogen dioxlde was determined exporimentally based on the composition of the effluent from the cyclone following the atomizer. The removal efficlency was low as shown in Figure 5. The efficiencies decreased from approximately 2.3 per cent for 10 per cent eNO 2 in the gas phase to less than 1 per cent for -1 per cent $\mathrm{eNO}_{2}$. This reduction in efficiency would be expected on the assumption that the rate of the chemical reactions controls the rate of absorption. The use of an ox dation catalyst 


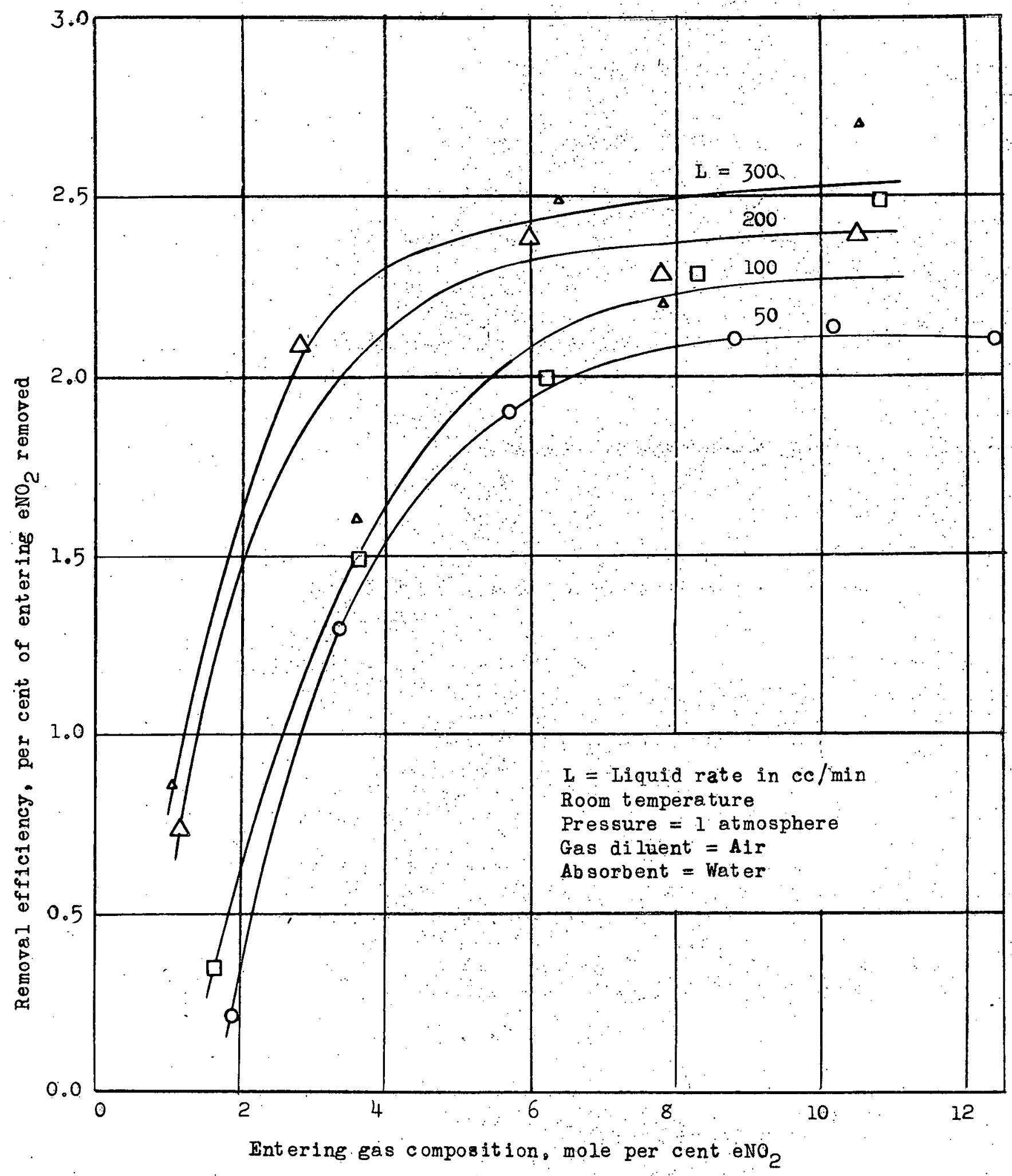

Figure 5. Effect of gas composition and liquid injection rate on recovery efficiency for nitrogen dioxide in Venturi atomizer 
(manganous sulfate) in the liquid gave no improvement in recovery efficiency. From the se results, it may be concluded that the short time of contact in the atomization zone overbalances the benefits of increased gas-liquid contact area, and the efficient recovery of nitrogen dioxide from gases by use of a Venturi atomizer does not appear to be feasible.

2. Fritted bubbler. The fine dispersion of the gas phase in a fritted bubbler gives a large gas-liquid contact area, and the time of contact at this large interfacial area is sub stantially greater than in a Venturi atomizer. Therefore, high rates of removal of nitrogen oxides from gases should be obtained with a fritted bubler. Experifiental tests with this type of equipment were carried out to determine the effects of liquid head, gas rate, and gaseous nitrogen dioxide concentration.

In the absorption of nitrogen dioxide from a gas containing 2.7 mole per cent $\mathrm{eNO}_{2}$, an eightrold decrease in liquid volume caused only a 10 per cent reduction in the amount of nitrogen dioxide absorbed. Thus, most of the nitrogen dioxide absorption occurred during the bubble formation in or near the fritteduglass surface.

A fourfold increase in the air rate from 0.05 to $0.2 \mathrm{cu} f t / m i n$ reduced the recovery efficiency by only 2 per cent. The substitution of pure oxygen for air increased the recovery of nitrogen dioxide by about 6 per cent while substitution of nitrogen for air caused a decrease of about 18 per cent in the rate of absorption of nitrogen dioxide. Thus, oxidation has some influence on the absorption in a fritted-glass disperser, but the oxidation is not the controlling factor.

The recovery efficiencies for nitrogen dioxide in the fritted-glass disperser are shown in Figure 6. These efficiencies are substantially higher 


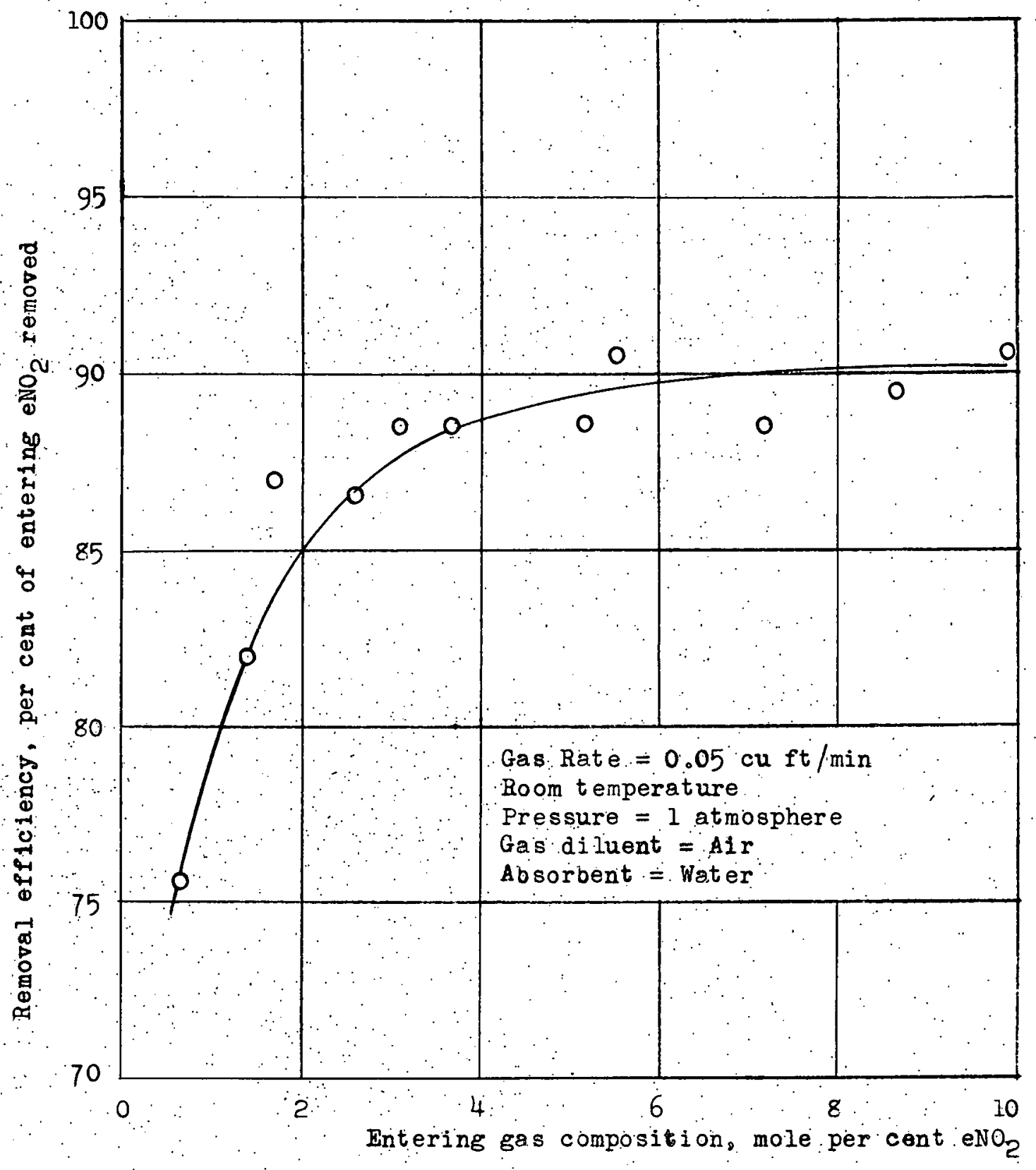

Figure 6. Effect of gas concentration on recovery efficiency for nitrogen dioxide in fritted-glass disperser 


\section{0}

than those reported for a bubble-cap column in Part I. The efficiency decreases from 90 per cent at a gas composition of 10 mole per cent $\mathrm{eNO}_{2}$ in air to 80 per cent at a gas composition of 1 mole per cent eNo 2 in air. This. decrease in removal efficiency with reduction in gas concentration agrees with the theory presented in Part I. Tests made with an aqueous sodium hydroxide solution in place of water or nitric acid as the absorbing medium showed increased removal efficiencios.

About 20 per cent of the total acid formed with the fritted-glass disperser was in the form of nitrous acid. while the pers cent of total acid as nitrous acid in the liquid product from a bubble-cap column was much less than 20 per cent. The groater percentage of total acid as nitrous. acid and the improved removal efficiency. With the fritted bubbler as compared with a bubble-cap absorber is due to the combination of increased gas-liquid contact area and contact time obtained with the fritted-glass disperser. These conditions would indicate that a considerable fraction of the total chemical reactions occurs in the liquid film when a frittedoglass disperser is used (2).

The high removal efficiencies obtained in this work with the fritted. bubbler show that this type of equipment may be useful for removing nitrogen oxides from gases. 


\section{PART IV: REMOVAL OF NITROGEN OXIDES. FROM DIIUTE GASES}

In the removal of nitrogen oxides from gases, it is usually desirable to reduce the oxide content to the lowest possible level. The maximum allowable concentration of nitrogen oxides in stack gases is in the range of 0.05 to 0.2 per cent by volume or 800 to 3200 parts per million. In.some processes, essentially all nitrogen oxides must be removed from gaseous products before the gases can be given further reeuvery lreatment.

Nitrogen oxides released to the atmosphere can be a factor in air poliution. Atmospher ic concentrations of nitrogen oxides as high as 0.4 parts per million have been reported in the Los Angeles region: however, these oxides are seldom present in sufficient extent to cause noticeable physiological effects. Since nitrogen dioxide can react with the water vapor in air or with rain drops to produce nitric acid, small concentrations In the atmosphere can cause undue corrosion on metal surfaces in the immediate vicinity of the releasing stacks. Plant life may also be damaged if the concentrations become excessive. The oxides of nitrogen can affect atmospheric pollution in an indirect manner by acting as catalysts. for certain reactions, such as the oxidation of sulfur dioxide.

This work was undertaken to determine the best methods for removing nitrogen oxides from dilute gases. The investigation has been confined to the removal. of...NO, $\mathrm{NO}_{2}$, and $\mathrm{N}_{2} \mathrm{O}_{4}$ from gases containing less than 2 volume per cent oxides. 


\section{A. Removal Processes}

There are two general processes which can be used for removing nitrogen oxides from gases: (1) by absorption combined with chemical reaction, and (2) by adsorption.

1. Absorption combined with chemical reaction. As indicated in Part I, when nitrogen dioxide is removed from a gas by contact with water, the rate of removal is controlled by the rate of the chemical reactions. l'he removal efticiency, therefore, tendas to decrease wilh reduchlun lu gaseous concentration of nitrogen oxides. At the low concentrations of interest in this work, poor removal efficiencies cen be expected unless very effective methods are used for contacting the gas and liquid. Another possible approach for increasing the removal efficiency would be to use a catalyst or other means to speed up the chemical reactions until diffusion becomes controling: however, no effective catalysts for this purpose have been reported (르).

Experimental data with foux types of absorption equipment have been obtained in this work. Tests were conducted using a bubble-cap tower, fritted bubbler, packed tower, and sproy tower.

\section{Adsorption. 'l'he results of Foster and Daniels (1) Indicate} that adsorption of nitrogen dioxide on silica gel gives good removal efficiencies even at gaseous oxide concentrations as low as 0.1 per cent. Mechanical factors, such as cycle changes aud desorption requirements, make the process more complicated than a continuous absorption operation: however, the method is capable of accomplishing essentially complete removal of nitrogen oxides from gases. 


\section{B. Experimental Equipment and Procedure}

1. Bubble-cap tower. Experimental dota were obtained using one bubble-cap plate containing seven bubble caps. One bubble cap was located in the center of the. plate and the other six caps were arranged perpherally around the center cap. Fight equally spaced circular slots of $5 / 16-1$ inch diameter were drilled in the center cap and four slots were drilled in each of the peripheral caps, these slots being directed toward the center to zeduce wall effects. The total depth of liquid on the plate was $I$ in. and the tops of the slots were $1 / 2$ in. below the liquid surface The Inside diameter of the glass column was $7-1 / 2$ ino, and there was a distance of 12 in. between the bubble-cap plate and the top and bottom plates.

2. Packed tower. The packed tower had an inside diameter of I in. and was packed to a height of 46 in. with $1 / 4-i n$. glass Raschig rings. Iiquid was introduced to the top of the column with the flow directed onto the center of the packing. Effective wetting of the packing was obtained and no channeling was observed.

3. Spray tower. The spray tower consisted of one No. T-58 spray nozzle having a nozzle diameter of $i \mathrm{~mm}$. The nozzle was directed countercurrent to a stream of gas rising through a l-in. inside-diameter tower. The distance from the bottom of the tower to the nozzie was 52 in. A baffled space above the nozzie reduced any iqquid carryover to a negligible amount. The nozzle delivered a finely dispersed spray which could be observed throughout the entire length of the column. Liquid product was withdrawn from the base of the tower and analyzed for combinedwitrogen content.

4. Fritted bubbler. Experimental data were obtained using a fritted bubbler consisting of 12 medium-frit glass rods (fritted area = 
1.03 sq. in. per rod). These rods were sealed into a lucite plate contained in a 5-1/2 in. inside-diameter column. The equipment was arranged so that the head of liquid above the frits could be varied from zero head to as much as 15 in. of head.

5. Controls. Water was fed to the units at a constant rate, and the flow rate was measured by a calibrated rotamet er and checked by volumetric measurements. Gaseous nitrogen dioxide, obtained from cylinders containing $\mathrm{NO}_{2}$ and $\mathrm{N}_{2} \mathrm{O}_{4}$, was diluted.with air and admitted ot a steady rate bo lie luwer section of the towers. The gas flow rates were measured by calibrated Venturi meters. Pressures at the top and bottom of the towers were measured by open- : tube manometers containing $\alpha$-bromonaphthalene. The temperatures of the entering liquid, entering gas, and exit liquid were determined by means of iron-constantan thermocouples.

6. Procedure. The towers were operated under steady conditions until equilibrium was attained as indicated by a constant acid concentration in the liquid product. Temperatures, pressures, and flow rates were read, and samples of the inlet gas, inlet liquid, and product liquid were taken. The : liquid samples were analyzed by titrating a known volume with standard NaOH solution. The gas samples were taken in evacuated bulbs containiar hydrogen peroxide. The amount of gas sample was determined by weighing, and the amount of nitrogen oxides present was determined by titrating the nitric acid formed from the reaction between $\mathrm{H}_{2} \mathrm{O}_{2}$ and $\mathrm{NO}_{2}$ and $\mathrm{N}_{2} \mathrm{O}_{4}{ }^{\circ}$

From a knowledge of the flow rates and concentrations, it was possible to calculate the removal efficiency expressed as the per cent of entering oxides removed. 
7. Choice of variables. It was necessary to choose the variables, such as gas rate, column height; and liquid rate, of magnitudes which would permit a fair comparison among the removal efficiencies of the various types of equipment. Water was used as the absorbent for all the runs involving absorption with chemical reaction. The removal efficiency was found to be independent of the liquid rate in the bubbie-cap tower and the fritted bubbler as long as the concentration of the liquid did not increase above 10 weight per cent nitric acid. The spray tower was operated at a liquid rate which would give a finely dispersed mist, while the packed tower was operated at approximately 90 per cent of the liquid flooding velocity.

The units were all operated at gas rates which would approximate conditions in industrial units. A slot gas velocity of $1.17 \mathrm{ft} / \mathrm{sec}$ was used in the bubble-cap tower, while the gas rate used in the fritted bubbler was the rate at which well-dispersed bubbles first appeared. Superficial gas velocities of $1.84 \mathrm{ft} / \mathrm{sec}$ were used in both the packed and spray towers. The efficiencies for the bubble-cap, spray, and fritted-bubbler units are all reported as obtained for a single contact stage. Since one stage of these units requires about one foot of height, the efficiency results for the packed tower are reported on the basis of one foot of packed height.

Air was used as the diluent gas for 0.11 the test runs. The gasliquid contact time in the bubble-cap and fritted-bubbler units was not sufficient for any appreciable oxidation of the No formed in the chemical reaction. Some of the NO formed was oxidized to $\mathrm{NO}_{2}$ in the packed and spray towers; however, this difference in the operation is necessary in order to 
make a fair comparison among the various types of equipment.

All runs were made at a pressure of one atmosphere and $25^{\circ} \mathrm{C}$, and filtered air was used so that no visible mist was formed in any of the runs. The efficiency results for the silica-gel adsorber are based on the data of Foster and Daniels (I) using a superficial gas velocity of $1.84 \mathrm{ft} / \mathrm{sec}$. packed height of 1.0 . ft, gel fraction saturation of 0.90 , and cycle time of 30 minutes. Adsorption capacities for gel No. 5 (I) were used, since Foster and Daniels indicate that this gei is one of the most efficient commerolal gels for nitrogen dioxide adsorption.

Table 1 gives a summary of the test conditions employed. It is believed that the choice of operating variables as outlined gives fals basis for comparing the results obtained with'the various types of equipment. The values chosen represent as closely as posslble those whiluh wula be used in corresponding industrial uaits.

\section{Discussion of Results}

Figure 7 presents comparative results showing the effect of entering oxide concentration on the removal efficiency for the different types of equipment. A reduction in exide concentration causes a decrease in removal efficiency for all the types of equipment. Thus, as the gases become more dilute, the removal problem becomes more difficult.

1. Spray tower. The results obtained with the singlemozzle spray tower indicate very poor removal efficiencies at gaseous oxide concentrations less than about $I$ per cent. At higher concentrations, the spray-tower efficlencies are comparable to those obtained in the other types of equipment. 
Pable 1

Test Conditions Used for Determining the Efflciency of Nitrogen Dioxide Removal from Dilute Gases with Different Types of Equipment.

\begin{tabular}{|c|c|c|c|c|}
\hline $\begin{array}{c}\text { Type } \\
\text { of } \\
\text { Equipment }\end{array}$ & $\begin{array}{l}\text { Gas Rate } \\
\text { ft } 3 \text { (S.C.) } \\
\text { per min }\end{array}$ & $\begin{array}{l}\text { Rate } \\
\text { cc } \\
\text { per min }\end{array}$ & $\begin{array}{c}\text { Pressure } \\
\text { Drop } \\
\text { cm } \mathrm{H}_{2} \mathrm{O}\end{array}$ & Remarks \\
\hline $\begin{array}{l}\text { Fritted-Glass } \\
\text { Bubbler } \\
\text { (one-stage) }\end{array}$ & $0.53 \because \because$ & 300 & 59.0 & $\begin{array}{l}\text { Medium frits. } \\
\text { Iiquid Head over } \\
\text { frits }=3-3 / 4\end{array}$ \\
\hline $\begin{array}{l}\text { Bubble-Cap } \\
\text { Tower } \\
\text { (one-stage) }\end{array}$ & $\begin{array}{l}1.06 \\
\text { (slot.ivelocity } \\
=1.17 \mathrm{It} / \mathrm{sec} \text { ) }\end{array}$ & 300 & 1.8 & $I^{\text {Liquid depth }}=$ \\
\hline $\begin{array}{l}\text { Packed Tower } \\
\text { (1/4" glass } \\
\text { Raschig rings) }\end{array}$ & $\begin{array}{l}0.53 \\
\text { (Superficial } \\
\text { vapor velocity } \\
=1.84 \mathrm{ft} / \mathrm{sec} \text { ) }\end{array}$ & $\begin{array}{l}150 \\
\therefore \\
\therefore\end{array}$ & $\begin{array}{l}2.0 . \\
\text { per foot } \\
\text { of pecked } \\
\text { height }\end{array}$ & $\begin{array}{l}\text { Packed height }= \\
46 \text {. Efficiency } \\
\text { as per foot of } \\
\text { packed height. }\end{array}$ \\
\hline $\begin{array}{l}\text { Spray Tower } \\
\text { ( I No. T58- } \\
\text { I mm spray } \\
\text { nozz le) }\end{array}$ & $\begin{array}{l}0.53 \\
\text { (Superficial } \\
\text { vapoi velucity } \\
=1.84 \mathrm{ft} / \mathrm{sec} \text { ) }\end{array}$ & & 1.0. & $\begin{array}{l}\text { Tower hei ght = } \\
52^{n} \\
\therefore\end{array}$ \\
\hline $\begin{array}{l}\text { Silica Gel } \\
\text { Adsorber } \\
\text { (No. } 5 \text { com- } \\
\text { mercial gel } \\
\text { - Ref. I) }\end{array}$ & $\begin{array}{l}0.53 \\
\text { (Superficial } \\
\text { vapor velocity } \\
=1.84 \mathrm{ft} / \mathrm{sec} \text { ) }\end{array}$ & & & $\begin{array}{l}\text { Packed height }= \\
12^{\prime \prime} \text {. Fraction } \\
\text { saturated }=0.90 . \\
\text { Time per cycle = } \\
30 \text { min. Effi- } \\
\text { ciencies calcu- } \\
\text { lated from Ref. } \\
\text { (I). }\end{array}$ \\
\hline
\end{tabular}




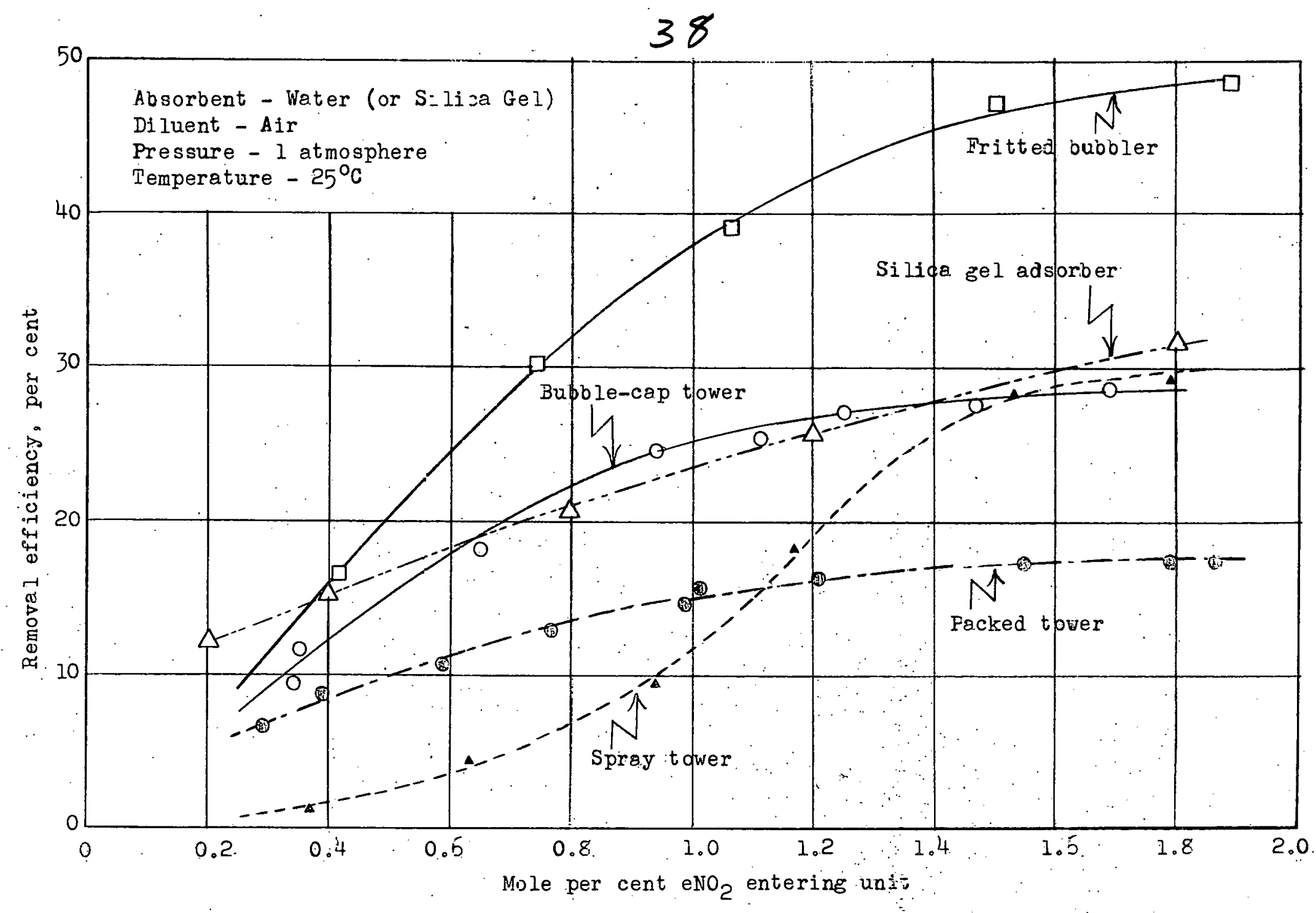

Figure 7. Efficiency of nitrogen dioxide removal from dilute gas with different types of equipment 
Absorption units employing multiple spray nozzles are often used in the nitrocellulose industry for removing nitrogen oxides from the fumes leaving the cellulose nitrator. These absorption units consist essentially of a horizontal stainless-steel tube having a diameter of 3 to 6 feet and a length ranging from 30 to 50 feet. Recirculated liquid is sprayed into the tube at various points along the length. A so-called "Piccolo" unit of this type is divided into compartments with a short packed section between each compartment. The liquid flows count ercurrent to the gases, and each compartment acts as a separate absorption system, permitting a graduation of acid strength from compartment to compartment. Over-all removal efficiencies as high as 80 per cent are claimed for these types of units with initial gas concentrations of approximately 0.5 per cent by volume nitrogen oxides and superficial gas velocities in the range of $3 \mathrm{ft} / \mathrm{sec}$. Therefore, despite the poor efficiencies obtained with a single spray nozzle, the use of multiple spray nozzles may be feasible for removal of nitrogen oxides from dilute gases.

2. Packed tower. The removal efficiencies with the packed tower are lower than those found with the bubble-cep tower or fritted bubbler. It should be noted, however, that the decrease in efficlency with reduction in oxide cont ent is fairly gradual, and, at nitrogen oxide concentrations less than about 0,2 per cent, the packed tower would be nearly as efficient as the other types of equipment. To permit oxidation of the No formed in a packed tower, it is best to operate at the lowest practical gas velocity. The superficial gas velocity of $1.84 \mathrm{ft} / \mathrm{sec}$ used in the experimental tests is close to the maximum velocity which should be used for nitrogen oxides absorption in packed towers. 
3. Bubble-cap tower and fritted bubbier. A fritted bubbler is merely a special type of a bubble-cap unit in which very small and well-dispersed gas bubbles are delivered into the absorbing liquid. A greater head of liquid for the gas bubbles to pass through is ordinarily uced in a fritted bubblex. From Figure 7 , it can be seen that the fritted bubbler gave much better removal efficiencies than the other types of equipment tested. The pressure drop per stage for the fritted bubbler was approximately 30 times greater then the equivalent pressure drop for the bubble-cap tower. Unless the gases were already under pressure, it would be expensive to add the equipment necessary to foree a gas through a number of fritted-bubblex stages.

- Since the removal efficiency of the bubble cap tower approaches that of the fritted bubbler at low gaseous oxide concentrations, the optimum type of absorption equipment should combine the good features of both operations. Figure 8 indicates that the gas rate and liquid head in the fritted bubbler have little effect on the removal efficiency as long as wellodispersed bubbles are formed and the liquid head is greater thon about 3 inches.

A bubble-cap unit desl gned with $\varepsilon$ number of small gas nutlets in the cope should apnrnximate the beneficial effects of the small bubbles and large gas-liquid contact area found in a fritted bubbler. At the same time, this design would reduce the pressure drop per stage to a practical value. The bubblecap unit should employ a. liquid head of at least 3 inches above the caps. This type of design should give efficiencies lying between the values shown in Figure 7 for the fritted bubbler and bubble-cap unit.

The effect of mist formation in a bubble-cap tower was considered in this work. It was possible to cause the formation of mist by using as a diluent air containing dispersed oil nuclei. While it might be expected that the added 


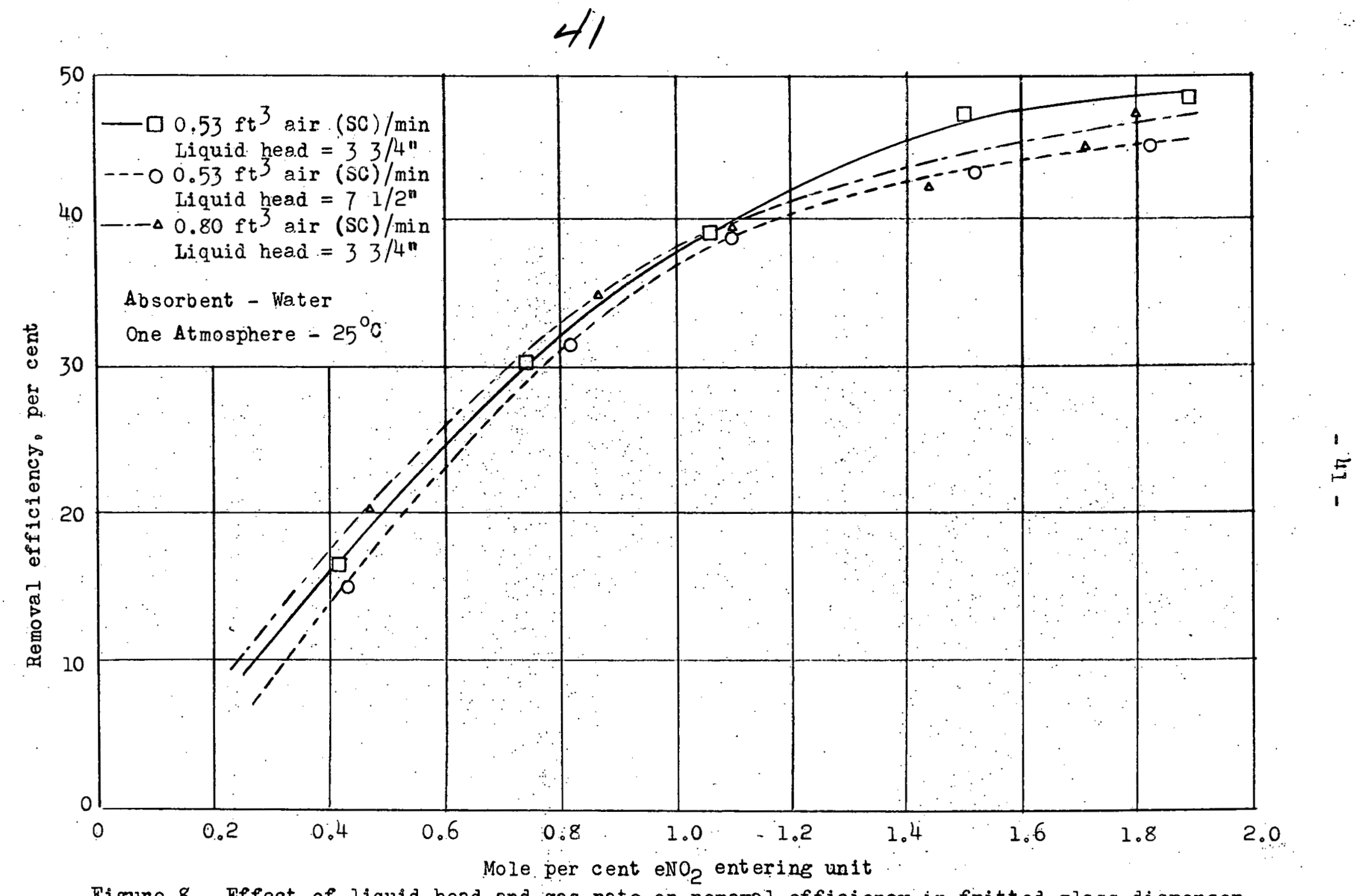

Figure 8. Effect of liquid head and gas rate on removal efficiency $\leq n$ fritted-glass disperser 
surface area of the mist particles would cause increased removil efficiencies, the experimental data indicated that lower efficiencies were obtained when mist was formed: Consequently, all runs reported here were made under conditions in which no visible mist was formed.

4. Silica-gel odsorber. The results shown in Figure 7 indicate that the silica-gel adsorber gives the best removal efficiency of the units tested at gaseous concentrations less than 0.4 per cent nitrogen oxides. If essentially complete removal of the oxides is necessary, the silicangel adsorber should be used since the removal efficiency does not fall off rapidy at low gaseous concentratione.

5. Effect of temperature and pressure. The shapes of the efficiency curves for the absorption equipment indicate that the absorption rate is primarily controlled by the rate of the chemical reactions. The reduction in efficiency with decrease in oxide content is caused by Iowered fractions of oxides present as $\mathrm{N}_{2} \mathrm{O}_{4}$ in the more dilute mixtures. An increase in total pressure or a decrease in temperature causes a greater fraction of the oxides to be present as $\mathrm{N}_{2} \mathrm{O}_{4}$. and would, therefore, tend to improve the removal efficiency (11; 12):

decrease in temperature or an increase in total pressure also increases the removal efficiency for the silica-gel adsorber. Figure 9 shows the effect of decreasing the temperature from $25^{\circ} \mathrm{C}$ to $10^{\circ} \mathrm{C}$ and the effect of raising the total pressure from 1 to 2 atmospheres. Figure 9 also indicates the sharp increase in removal efficiency obtained by decreasing the cycle time in the silica-gel adsorber. 


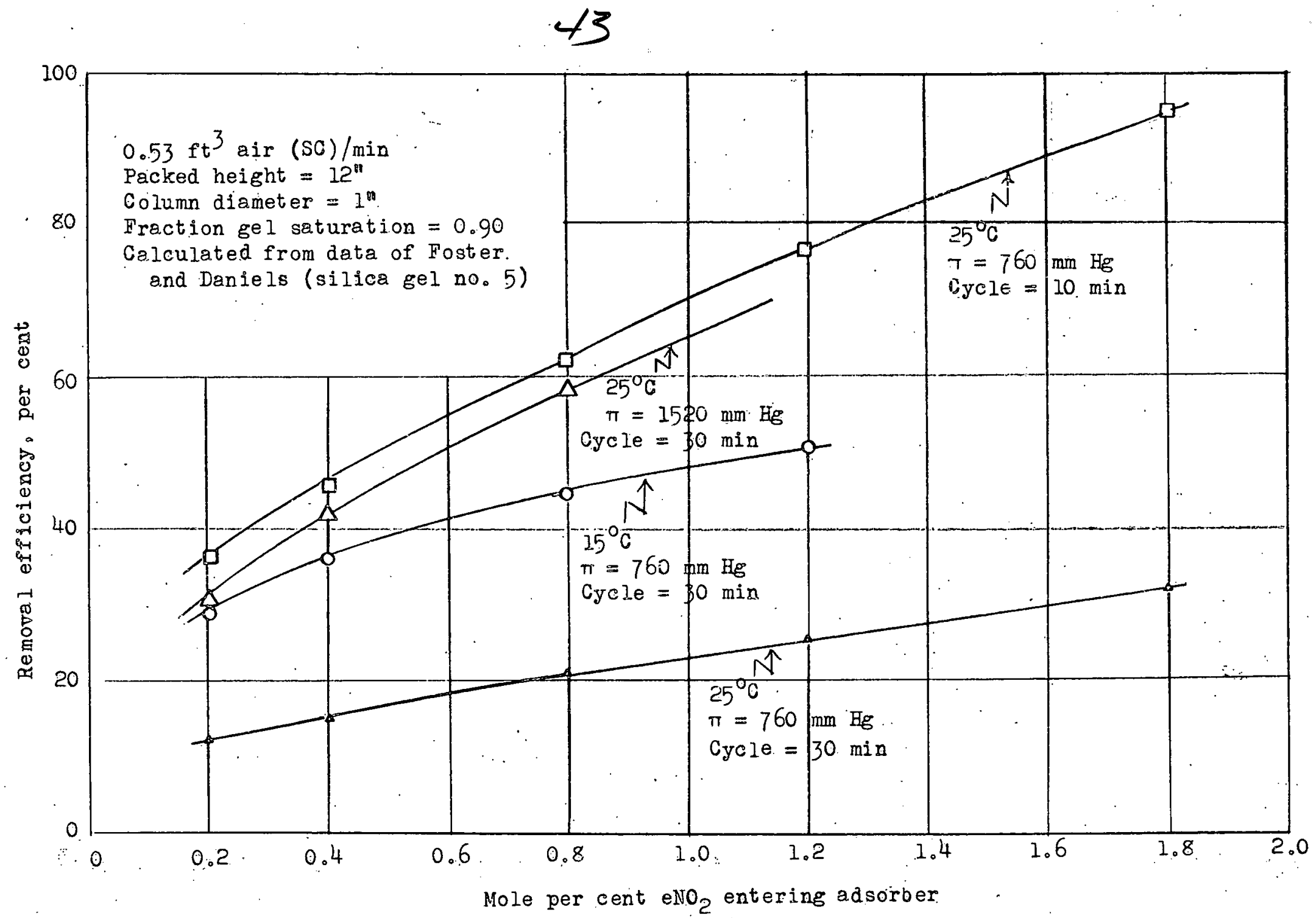

Figure 9. Effect of temperature, pressure and cycle time on removal efficiency in silica gel adsorber 
D. Summary of Study on Removal of Nitrogen Oxides

\section{from Dilute Gases}

Data were obtained on the efficiency of nitrogen oxides removal from dilute gases using bubble-cap, paoked, spray, Iritted-bubbler, and silicam. gel adsorption towers. The efficiencies were determined under conditions which would make possible a fair comparison of the differ ent methods. The tests were limited to dilute gaseous mixtures containing less than 2 volume. per cent nitrogen oxides. Water was used as the absorbing medium and air was used as the gaseous diluent.

The results indicat that single-nozzle spray towers are inefficient for removing nitrogen oxides at low gaseous concentrations, although better results would be expected with multiple-spray units: Fritted bubblers give the best removal efficiency among the different types of absorption equipment tested. The high pressure drop with a fritted bubbler causes this type of equipment to be impractical for most industrial operations. Therefore $a$ special bubble-cap plate design is recommended which would reduce the pressure drop and still include the best footures of the fritted bubbler.

Comparison of the virious types of equipment indicates that the silicagel adsorber is superior if it necessary to remove essentially all of the nitrogen oxides from a gas. 


\section{PART V. EFTICIENCY OF AQUEOUS ABSORPTION OF NITROGEN}

OXIDES WITH MUITISTAGE BUBBLF-GAP COLUM

The experimental results discussed in Part I were obtained by using a bubble-cap colum containing one plate. A subsequent investigation was conducted to determine if the same type of results would be obtained when a multiple-plate bubble-cap column was used in place of the single-plate column. At the same time, a study was made on the effect of mist formation during the aqueous absorption of nitrogen oxides.

The individurl plate efficiencies with the multiple-plate column increased significantly for each succeeding contacting stage, and an incrèase in plate efficiency was observed as the amount of mist formation decreased. These results are presented and interpreted in this section.

\section{A. Experimental Equipment}

Experimental data were obtained using a bubble-cap column containing three identical plates, with auxiliary equipment as shown in Figure 10: Fach plate was made of $1 / 2$-inch Lucite and was equipped with seven bubble caps and seven gas risers made of polystyrene. Eight equally-spaced circular slots of 5/16-inch diameter were drilled in the center cap. and four slots of the same diameter were drilled in each of the six periphergl caps. The slots in the peripheral caps were directed toward the center to reduce wall effects. The total slot area per plate was 2.46 square inches, which gave a slot. velocity, in feet per second, approximately equal to the gas rate in cubic feet per minute. The tops of the slots were $1 / 2$ inch below the liquid surface, and the total depth of liquid on each plate was 1 inch. 
$-46-$

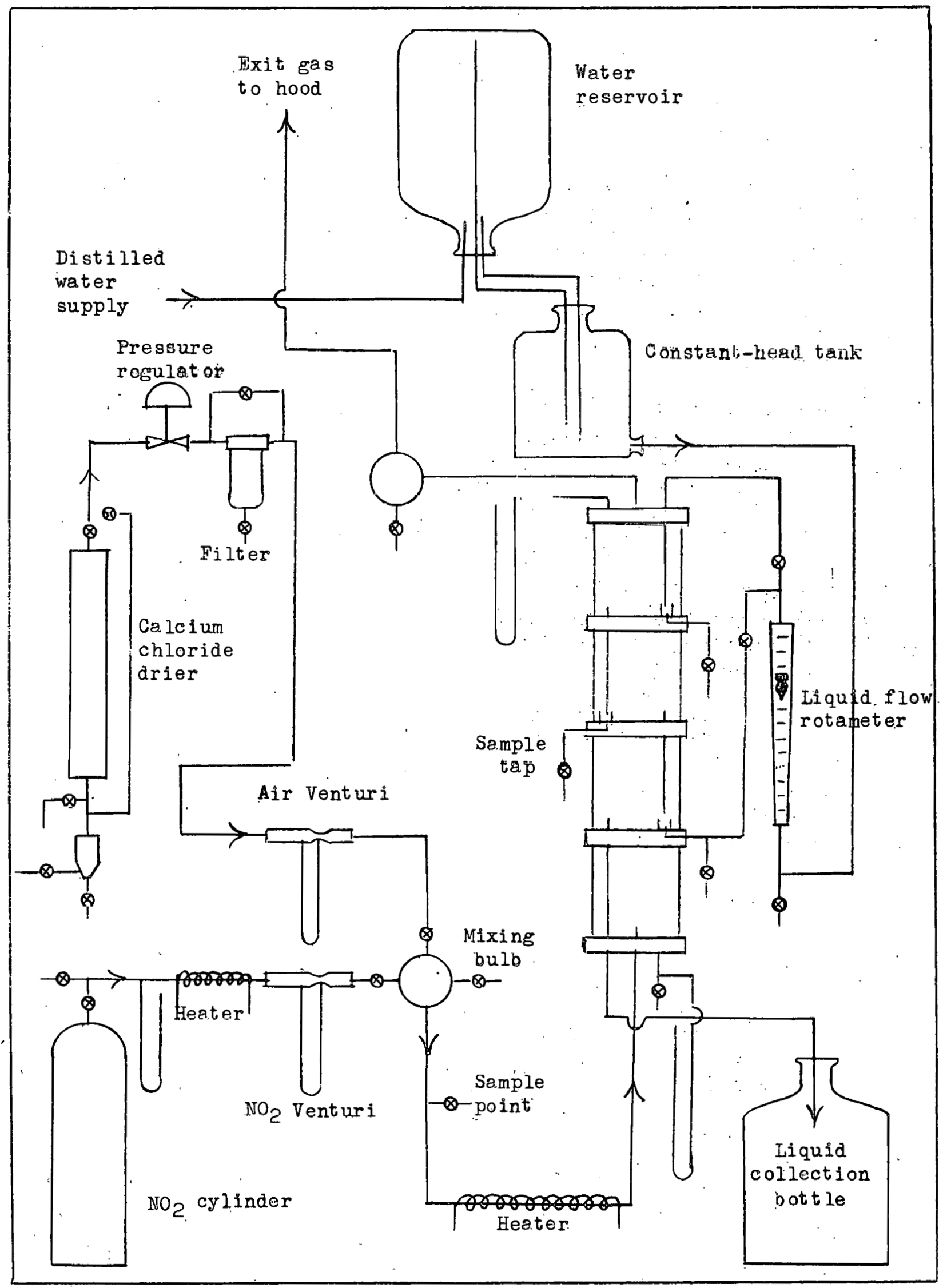

Figure 10. Experimental equipment for tests with multistage bubble-cap column 
The Inside diameter of the glass sidewalls was $7-1 / 2$ inches. The 12-inch high sections set the distance between the bubble-cap plates and the top and bottom stainless-steel plates. Transfer of liquid from one tray to the next. lower tray was effected by the use of stainlessusteel downcomers which discharged into a well on the delivery plate.

Water was fed to the top tray through a downcomer projecting: through the stainless-steel top of the tower. Samples of the liquid leaving the top and midde platoo wero withdrawn from the well on the next lower plate using the tap provided. The liquid leaving the last tray was sampled, and the flow rate of the discharged liquid was measured.

Gaseous nitrogen dioxide was mixed with air. The mixture was sampled and admitted to the lower section of the tower. The air flow. rate was measured by a glass Venturi meter which had been calibrated against a standard rotameter. The nitrogen dioxide flow rate was also measured by a. Glass Venturi meter. The reading provided by this Venturi meter was helpo ful in setting the range of gas compositions desired and provided a check on succeeding runs.

The air obtained from the laboratory supply lines passed through a. cyclone, a calcium chloride drying tube, a pressure-regulating valve, and a filter before being measured and mixed with the incoming nitrogen dioxide. Provision was made for by-passing both the drier and the filter in order to permit mist formation in the absorption tower.

Pressures at the top and bottom of the column were measured by open-end manometers containing ambromonaphthalene。 The same indicating * fluid was used in the Venturi manometers: 
Temperatures at the following points were meașured by iron-constantan thermocouples: (1) Bntering No 2 gas, (2) gas mixture before heater, (3) gas mixture after heater. (4) gas entering bottom plate; (5) gas entering middle plate, (6) gas entering top plate, (7) exhaust gas, (8) entering water, (9) liquid leaving top plate, (10) liquid leaving middle plate, and (11) liquid leaving bottinm plate.

Each plate was fizted wilh \&. 3-fuut sobinloodotool sooline rnil made from 1/4-inch tubing. Cooling water was not circulated, however, because preliminary runs indicated that the maximum temperature gradient across the tower was less than two degrees Centigrade.

\section{B. Procedure}

All experimental tests were made at a liquid flow rate of $300 \mathrm{cc}$ per minute and a gas slot velocity of 1.2 feet per second. Distilled water was used as the absorbing medium and the gas composition ranged from 0.5 to $8_{n} 0$ mole per cent $\mathrm{NO}_{2}$. All runs were made at atmospheric pressure and room temperature,

When the tower was to operate without the presence of mist, the supply air was passed through the drier and filter before entering the absorption unit.' If mist was desired, the air was passed into the tower without going through the drying and filtering stages.

During the progress of a run, the air rate and liquid rate were set and blank samples of the gas and lịquid were taken. The desired gas concen tration was then obtained by admitting nitrogen dioxide, end the unit was operated at steady condi tions for approximately one hour until equilibrium conditions were obtained. The nitrogen dioxide was supplied from heated 
cylinders obtained from Allied Chemical and Dye Corporation ( 98 per cent purity)。

After equilibrium conditions were attained, two samples of the entering gas and the liquid leaving each tray were taken. All rates, temperatures, and other pertinent data were recorded. Gas samples were taken in evacuated 200-mi bulbs fitted with selfosealing rubber stoppers. The bulbs contained hydrogen peroxide and the evacuation and sampling were accomplisher hy use of 18-gauge hypodermic needles. The bulb containing the gas sample was. shaken for one hour to permit: complete reaction of the nitrogen dioxide. The bulb contents were then titrated with sodium hydroxide solution using bromcresol green methyl red mixed indicator. The percentage of nitrogen oxides in the entering gas was determined from. the weight of the gas sample and the results of the titration.

The liquid samples were analyzed for combined nitrogen cont ent by titrating with sodium hydroxide solution. Plate efficiencies were calculated as the amount of oxides removed from the entering gas divided by the amount of oxides which theoretically could have been removed if the absorption reaction had gone to completion.

\section{Discussion of Results}

When runs were made using unfiltered air, a mist invariably appeared over the liquid surface if any nitrogen oxides were present in the gas. However, the mist was not apparent when filtered and dried air was employed. It appears, therefore, that the formation of mist is des pendent on the presence of suitable nucle1, such as dispersed oil particles, on which a condensation may take place. The density of the mist was apos 
parently a function of the number of nuclei available, and there was no observable variation in mist density throughout the column. In this work, the impurities present in the laboratory air supply were used as a source of nuclei. The concentration, size, and composition of the aerosol involved was not a controllable factor, and the density of the mist obtained in these tests was less than that in the experimental tests discussed in Part $I_{0}$

The sharacteristic efficiency curves for the three plates of the absorption unit, operated with mist, are shown in Figure il. Figure 12 is a similar plot for the unit operated without mist. In both cases there is a defim nite trend toward greater plate efficiency as the gas passes up the tower.

The following factors could hare an influence on the efficiency of the Individual trays:. - the concentration of acid on the tray, the temperature of the gas or liquid on the tray, the gas rate, the concentration of No in the gas phase, and the concentration of water, vapor or mist in the gas phase. Prerous work (11, 12) has shown that the absorption rate is not noticeably. changed when 15 per cent nitric acid is used as the absorbing medium in place of water. In the work reported here, the change in the gas rate and temperature of the gas and liquid phases in the unit was not appreciable. Using the method outlined by Sherwood and Pigford (13), it can be shown that the No concentration In the gas has no effect on the plate efficiency at the liquid and gas concentrations encountered in this work.

If part of the chemical reaction takes place in the gas phase, a higher concentration of water vapor in this phase would be an advantage, and an increase in plate efficiency might be expected if the water vapor pressure increases. In the present experimental work, the air was brought into the base of the tower essentially dry. As the gas moved up the tower: its water-vapor 


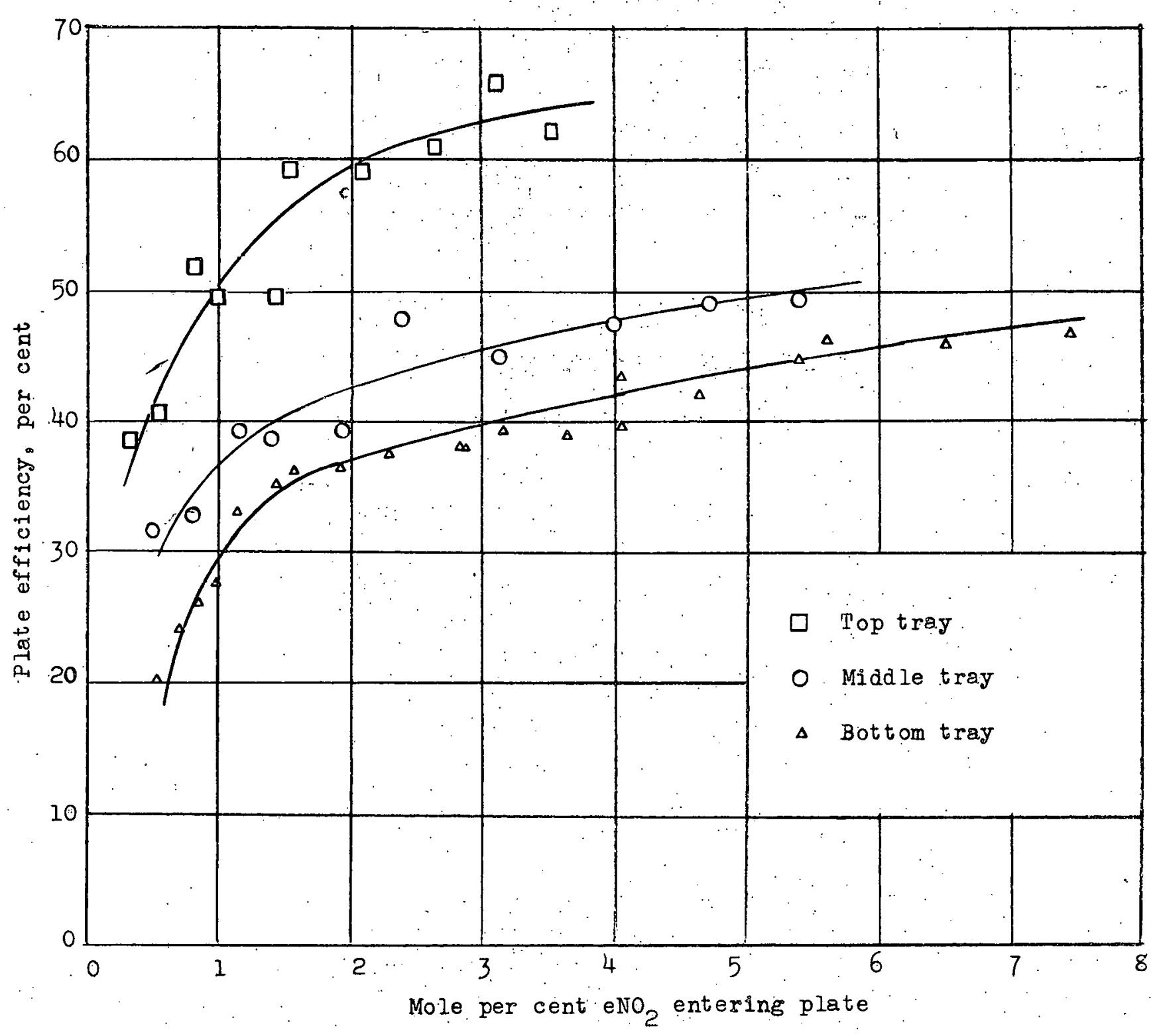

Figure 11. Effect of eNO 2 concentration in entering gases on plate efficiency with three-plate bubble-cap column and medium mist 


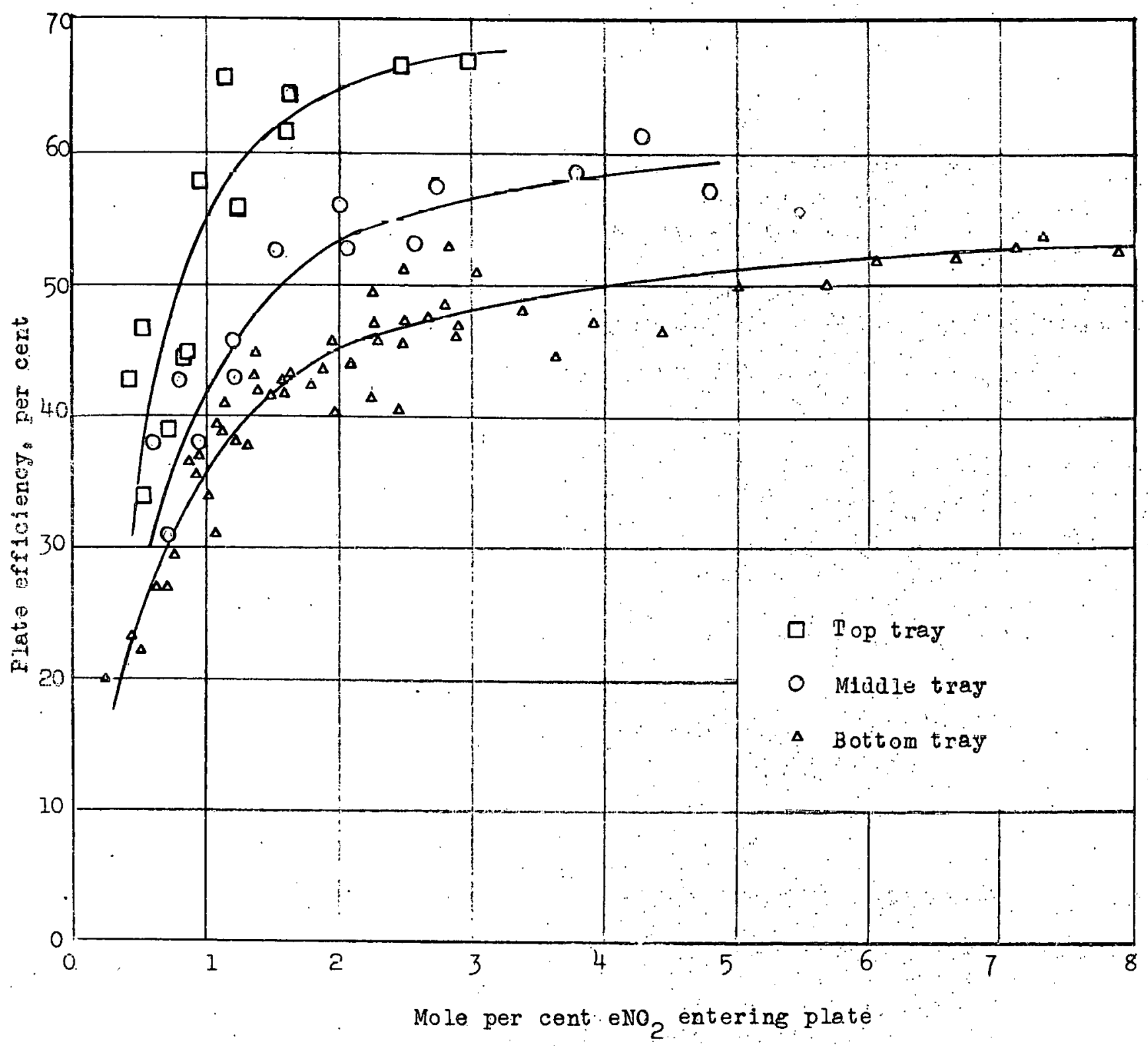

Figure 12. Effect of $\mathrm{eNO}_{2}$ concentration in entering gases on plate efficiency with three-plate bubble-cap column and no observable mist 
content increased. At the gas velocity used. it is believed that saturation could not be at tained in one plate contact, but would require several contacts. Therefore, the increase in plate efficiency from the bottom to the top tray may have been caused by the increasing concentration of water vapor in the gas phase.

If the individual plate-efficiency curves for the top, middle, and bottom plates, with and without mist, are compared, the efficiency is lower in each case for the runs in which mist was present. Thus, the presence of mist appears to cause a decrease in the rate at which nitrogen oxides are removed from gases. Comparison of the curves in Figures 11 and 12 gives no indication that the reduction in efficiency with mist present is due to carryover in the mist.

The shapes of all the curves in Figures 11 and 12 approximate the results that would be expected if the chemicol reaction rates control the rate of removal of nitrogen oxides. Careful analysis of the results indicate that, when no mist is present, the absorption rate is completely controlled by the rate of the chemical reactions at gaseous concentrations less than about 2 volume per cent eNo, At higher concentrations, diffusional resistances start to become important. The results in the presence of mist come closer to representing conditions which would be predicted if the chemical reaction rates were controlling. Apparent $1 \mathrm{y}$, the mechanism controlling the rate of absorption of nitrogen oxides at gaseous concentrations higher than about 2 volume per cent eNo 2 depends partially on the density of the mist and the type of contacting equipment. 
D. Summary of Results Obtained with Multistage Bubble-Gap Column

When multistage bubble-cap units are employed for aqueous absorption of nitrogen oxides, the individual plate efficiencies increase for any given gas composition as the gas moves up the tower. Higher plate efficiencies are obtained if no mist is present. For the design of a bubble-cap absorption unit, the use of all plate efficiencies based on values applicable at the bottom tray with mist present in the gas would give a good safety factor for the final design。

At low cuncentrationo of nitrne dioxide in the entering gases, the rate of the chemical reactions controls the rate of removal of nit rogen oxides. high gaseous concentrations, diffusional resistances as weil as chemical reaction rates, may determine the rate of nitrogen oxides removal, especially if there is little mist present in the gas。 


\section{PART VI. CAUSTIC ABSORPTION OF NITROGEN OXIDES FROM GASES}

The rates of the chemical reactions involved in the aqueous absorption of nitrogen oxides are a major pactor in determining the rate of removal of nitrogen oxides from gases. The important chemical reactions occur partially in the gas phase and partially in the liquid phase. One possible way to increase the rate of chemical reaction in the liquid phase would be to employ an aqueous sodium hydroxide solution as the absorbing medium。

Sodium hydroxide reacts with equivalent nitrogen di oxide as fol:lows:

$$
\text { 2. } \mathrm{NaOH}+2 \mathrm{NO}_{2}\left(\mathrm{Or}: \mathrm{N}_{2} \mathrm{O}_{4}\right) \longrightarrow \mathrm{NaNO}_{2}+\mathrm{NaNO}_{3}+\mathrm{H}_{2} \mathrm{O}
$$

If the reaction rate constant for the preceding equation is sufficient ly large, it would be possible for this, reaction to proceed so rapidy that the diffusion of gaseous nitrogen dioxide to the liquid surface would ultimately. control the rate of oxide absorption. This would result in an increased efficiency for the gaseous-oxide removal. However, if the rate for the sodium hydroxide reaction is not appreciably greater than the rate for the corresw ponding liquid-phase water reaction, the overall absorption efficiency could be reduced when caustic solution is used. This reduction in efficiency would be caused by a decrease in the rate of the gas phase reaction because of the lowering of the water vapor pressure.

Previous studies made with wetted-wall absorption units (4, 6) have indicated that the rate of nitrogen oxides absorption into caustic solutions is less than into water or dilute nitric acid solutions. The same result at temperatures higher than $80^{\circ} \mathrm{F}$ was indicated in Part II. Andersen 
(1, 2) found an increase in removal efficiency for nitrogen oxides when caustic solution was substituted for water as the absorbing medium in a frit ted-bubbler absorption unit.

The present study was conducted to determine the role of aqueous solutions of sodium hydroxide in the removal of nitrogen oxides from gases with a hubble-cap absorption unit. The results indicate that dilute sodium hydroxide solutions in bubble-cap columns are no more efficient than water for removal of nitrogen oxides.

\section{A. Experimental Apparatue and Procedure}

The experimental equipment used was similar to the three-plate Dubile-cap column described in Part $V_{g}$ and the same general procedure was used. Since accurate analyses of the nitrate and nitrite concentrations in the liquid product could not be obtained at high concentration of sodium hydroxide, an attempt was made to base the results on accurate analyses of the entering and leaving gases. The conventional method of analysis described in Part $V$ gave good results for the entering-gas samples. However, accurate analyses of the exit gas could not be obtained unless mist was absent from the gas.

A. large number of experimental tests were conducted with water as the absorbent under conditions of no mist, and the exit gas was analyzed by the procedure given in Part II. Material balances based on rates and analyses of entering gas, leaving liquid, and leaving gas indicated that the exit-gas analyses were essentially correct. A heavy mist was obtained in the gas phase when water was replaced by concentrated sodium hydroxide as the absorbing medium, even though filtered and dried air was used as the gas 
diluent. For this reason, all the reported results are for aqueous sodium hydroxide concentrations of 3.6 per cent by weight or less, and all calcum lations are based on rates and analyses of the entering gas and leaving liquid.

Removal efficiencies are reported as the fraction of entering nitrogen dioxide (including $\mathrm{N}_{2} \mathrm{O}_{4}$ ) removed by the three-plate bubble-cap unit. A gas slot velocity of 1.2.ft/sec and a liquid flow rate of appoximately $320 \mathrm{cc} / \mathrm{min}$ were used in all runs. Enteringmas concentrations varying from 3 to 8 volume per cent eNO 2 were tested, and the sodium hydroxide con centration in the runs was varied from 3.6 to 0.0 weight per cent.

\section{B. Discussion of Results}

Within the limits of experimental error, no significant difference in absorption rate was observed when water, 1 per cent, 2 per cent, or 3.6 per cent sodium hydroxide solution was used as the absorbing medium. The over-all removal efficiency for the three plate bubble-cap column was in the range of $82-92$ per cent at a gas composition of 8 volume per cent eNO $_{2}$, and the removal efficiency decreased steadily to 70-80 per cent at a. gas composition of 3 volume per cent eNO $2^{\circ}$ (See Appendix for experimental results.)

No definite trend in the removal efficiency was observed with increase in sodium hydroxide concentration. This result would be expected if the reaction with sodium hydroxide does not proceed at a rate considerably faster than the equivalent reaction with water, since the water vapor pressure over 3.6 per cent sodium hydroxide solution is only slightly less than the vapor pressure of pure water. 
While only low concentrations of sodium hydroxide were tested in this work, excess sodium hydroxide was present during the runs made at the two highest liquid concentrations. Therefore, a definite increase in removal efficiency should have been observed for these runs if the rate of the reaction with sodium hydroxide reaction is greater than the equivalent reaction with water. Since tripling the concentration of sodium hydroxide had no effect on the removal efficiency, it may be assumed that the contacting mechanism in a bubble-cap column is such that essentially the same results with caustic solutions are obtained in both wetted-wall and bubble-cap absorption units. The use of aqueous sodium hydroxide as the absorbing medium for nitrogen. dioxide in a bubble-cap column does not cause on increase in the rate of gaseous-oxide removal and may cause a reduction in the removal efficiency. 


\section{PABR VII. SUMMARY}

This report presents the results of research program conducted to obtain a fundamental understanding of the principles governing the removal of nitrogen oxides from gaseous mixtures and to develop improved methods for the removal process. A detailed study of the mechanisms controlling the rate of aqueous absorption of gaseous nitrogen oxides was made. and an analysis of the controlling mechanism was developed on the basis of chemical kinetics. The roles of gas-phase and liquid-phase reactions, as well as mist formation, were investigated. Various types of equipment and processes for removing nitrogen oxides from gases were tested.. These in cluded bubble-cap columns, wetted-wall columns, Venturi atomizers, fritted bubblers, packed columns, and spray columns. Water, aqueous nitric acid. aque ous sodium hydroxide, aqueous sodium chloride, and silica gel were cxamined as media fur removing nitrogen oxides from gases. Extensive tests were conducted with a bubble-cap absorption unit to determine the basic mechanisms controlling the rate of nitrogen oxides removal from gases. Pure water and dilute nitric acid were used as the absorbing media, and gaseous concentrations ranging from 0.5 to 10 volume per cent eNO 2 were tested. The individual plate efficienoies decreased with reduction in gaseous-oxide concentration. This indicated that the rates of the chemical reactions involved in the removal process were controlling. An analysis of the results, based on chemical kinetics。 permitted an excellent correlation of the experimental data when mist was present in the gases. An equally good correlation on the same basis has been found to apply for wetted-wall absorption units. With other types of contacting equipment, such as fritted dispersers or bubble-cap units with 


\section{$-60-$}

no mist present, the chemical reaction rates were controlling at gaseous concentrations less than about 2 volume per cent eNO${ }^{\circ}$

A wetted-wall absorption unit was used to examine the roles of gasphase and liquid-phase reactions. The results indicated that part-of the reaction occurs in each phase. Studies were made on the effects of mist formation. The mist formed only when suitable nuclei, such as dispersed oil droplets, were present in the gases. The presence of mist caused a reduction in the rate of removal of gaseous oxides when a lubble-cap contacting system was employed. Comparative results with various types of equipment showed that Venturi atomizers Were very inefficient for removing nitrogen oxides from gases. Fritted dispersers and silica-gel absorbers gave better removal efficiencies than the other types of equipment tested. Packed towers and single-nozie spray towers were not as effective for removing gaseous nitrogen oxides as bubble-cap towers.

Tests with a mutistage bubble-cap tower indicated an increase in plate efficiency as the gases moved up the tower.o. The use of aqueous caustic solutions as the absuruing meda in place of water indicated that sodium hydroxide cannot be used with a bubble-cap or wetted-wall absorption unit to obtain more complete rémuval uf nitrogon oxides frnm gaseous mixtures.

The basic objects of this research program have been achieved. The careful analyses of the controlling mechanism in the removal operation, combined with the work on gas-phase reactions, liquid-phase reactions, and mist formation, serve to give an understanding of the principles involved in removing nitrogen oxides from gases. The experimental test a show the types of equipment which are most effective and also indicate the approach, operating conditions, and design data which can be used in the development of new and 
improved methods for removing nitrogen oxides from gases.

Further work in this fie ld will be conducted. Investigations dealing with agitated absorption units, multiple spray units, quantitative data on the kinetics of the important oxide-removal reactions, and mist formation are planned. 


\section{TAB̈LE OF-NOMENCIATURE}

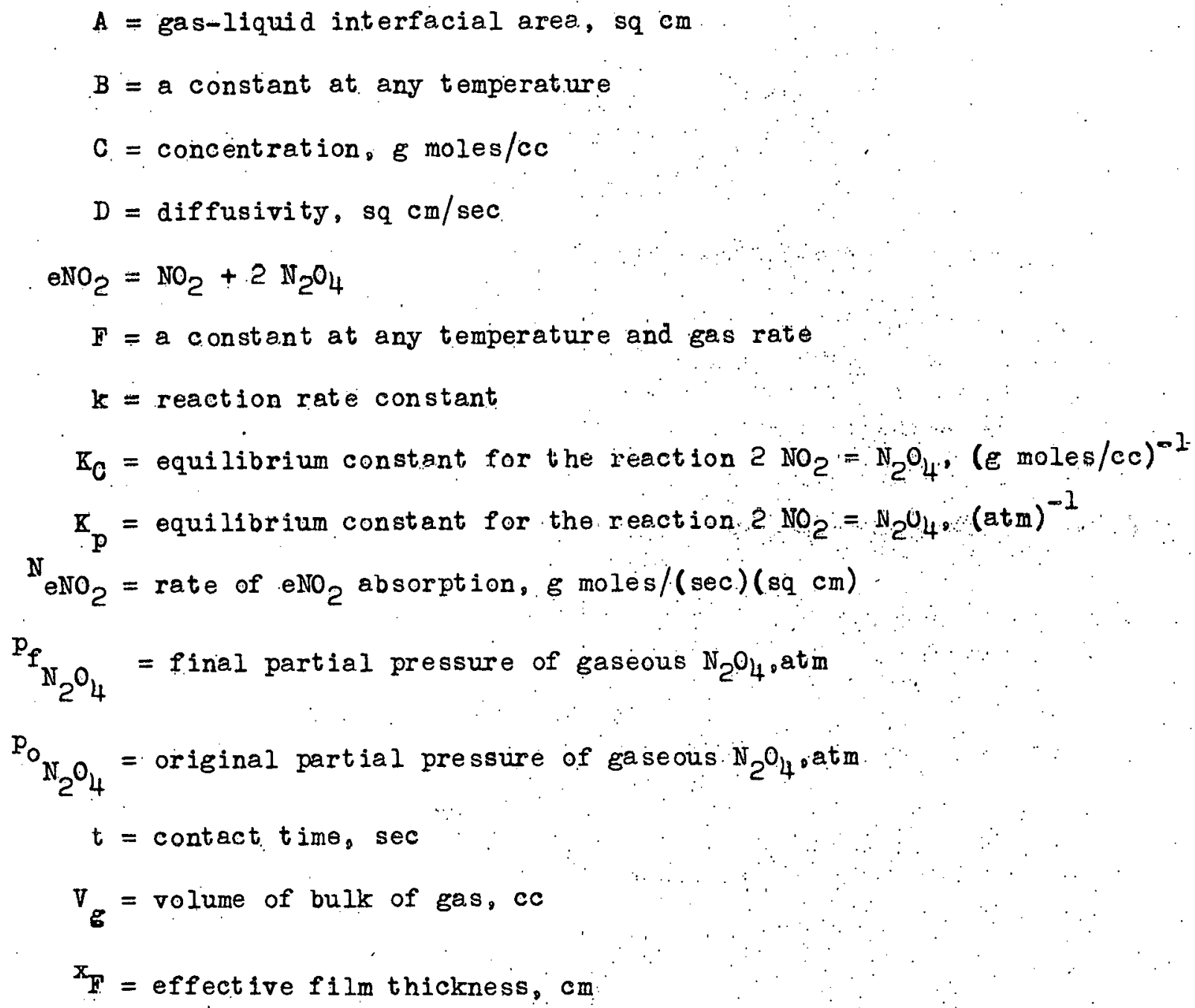




\section{BIBIIOGRAPHI}

1. Andersen, I. B.. "Absorption-Oxidation Processes in Dispersed Media, Ph. D. Thesis in Chem. Eng.o. Unit, of III. (1954).

2. Andersen, L. B., and Johnst one, Ho. F. . A. I.Ch.E. Journa I, I. 136 (1955).

3. Caudle, P. G., and Denbigh, K. G. Trans. Far. Soc.0.49, 39 (1953)。

4. Chambers, F. S. and Sherwood, T. Ko, Ind. Engo Chem。o 29. 1415 (1937).

5. Denbigh, K. G., and Pxince, A。 Jo, J. Ghem. Soc., 790 (1947):

6. Eagleton; L. G., Langer, $R_{0} M_{0}$ and Pigford, T。H. S. M。 Thesis, M.I.T. (1948).

7. Foster, E. Go, and Daniels, Fo. Ind. Eng. Chem。. 43, 986 (1951)。

8. Holman, J. L., Vapor and Liquid Phase Reactions Between Nitrogen Dioxide and Water "M. S. Thesis in Chem. Eng. Univo of III. (1954).

9. Klein。 J.E. "Efficiency of Aqueous Absorption of Nitrogen Oxides with Multistage Bubble-Cap Colum, M. S。 Thesis in Chem。 Eng.o. Unito of I11. (1954)。

10. Peters, M. S. and Holman; $J_{0} L_{0}$. accepted for publication in Ind. Eng. Chem. (1955)

11. Peters, M. S., Ross, $C_{0} P_{0}$, and Andersen, L. $_{0} B_{0}$. Memoval of Nitrogen Oxides from Gaseous Mixtures,". Univ, of Ill. Engo Expt. Sta. Tech. Rept.No.10,A.E.C.Contract No. AT (30,3)-28, Serial No.600-1011。 Sept. 30。 1953.

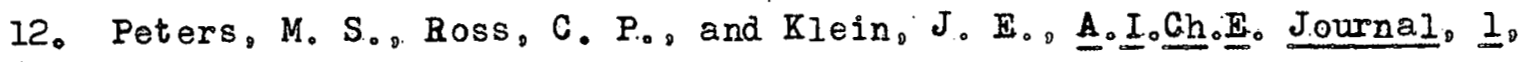
$105(1955)$.

13. Sherwood, T. K., and Pigford, R. I., Absorption and Extract ion $n_{\theta}$ ind Ed. McGraw-Hill Book Co.. Inc. New York (1952)。

14. Wenner, B. R., "Thermochemical Calculations, McGraw-Hill Book Co., Inc o. New York (1941). 


\section{APPENDIX}

\section{SAMPIE CALCULATIONS}

A. One-Plate Bubble-Cap Plate Column

1. Sample calculations showing the method of determining plate efficiency and the concentration of $\mathrm{NO}_{2}$ and $\mathrm{N}_{2} \mathrm{O}_{4}$ are presented in Technical Report No. 10, A.E.C. Serial No. C00-1011 (11).

2. Sample calculation for sensitivity of correlation of data based on integrated rate equation

$\underline{\text { Run Number }} \underline{4}=\underline{\text { Tabje }} \underline{\underline{2}}$

\section{Entering Gas (Mole \%)}

$\mathrm{NO}_{2}+2 \mathrm{~N}_{2} \mathrm{O}_{4} \quad \mathrm{NO}_{2}: \mathrm{N}_{2} \mathrm{O}_{4}$

keported

$$
0.685
$$

0.628

0.0286

$0.685-(0.685-0.576)(0.5)=0.631$

$0.582 \quad 0.0244$

Conversion $=50 \%$

Conversion $=200 \%$

of reported value

$$
0.685-(0.685-0.576)(2.0)=0.467 \quad 0.4390 .0139
$$

Beported

$$
\begin{aligned}
\text { Abscissa } & =\sqrt{\frac{1}{\mathrm{p}_{\mathrm{N}_{2} \mathrm{O}_{4}}}-2 \sqrt{\mathrm{k}}} \text { In } \frac{\mathrm{p}_{\mathrm{N}_{2} \mathrm{O}_{4}}}{\mathrm{p}_{\mathrm{N}_{2} \mathrm{O}_{4}}}=\sqrt{\frac{1}{0.000286}}-2 \sqrt{7.024} \ln \frac{0.000286}{0.000206} \\
& =57.4 \\
\text { Ordinate } & =\sqrt{\frac{1}{\mathrm{p}_{\mathrm{N}_{2} \mathrm{O}_{4}}}}=\sqrt{\frac{1}{.000206}}=69.7
\end{aligned}
$$

Value of ordinate from mean line at abscissa of $57.4=67.5$

Per cent error of reported value $=3.3 \%$ 
Average deviation of all experimental ordinates from mean $=2.8 \%$

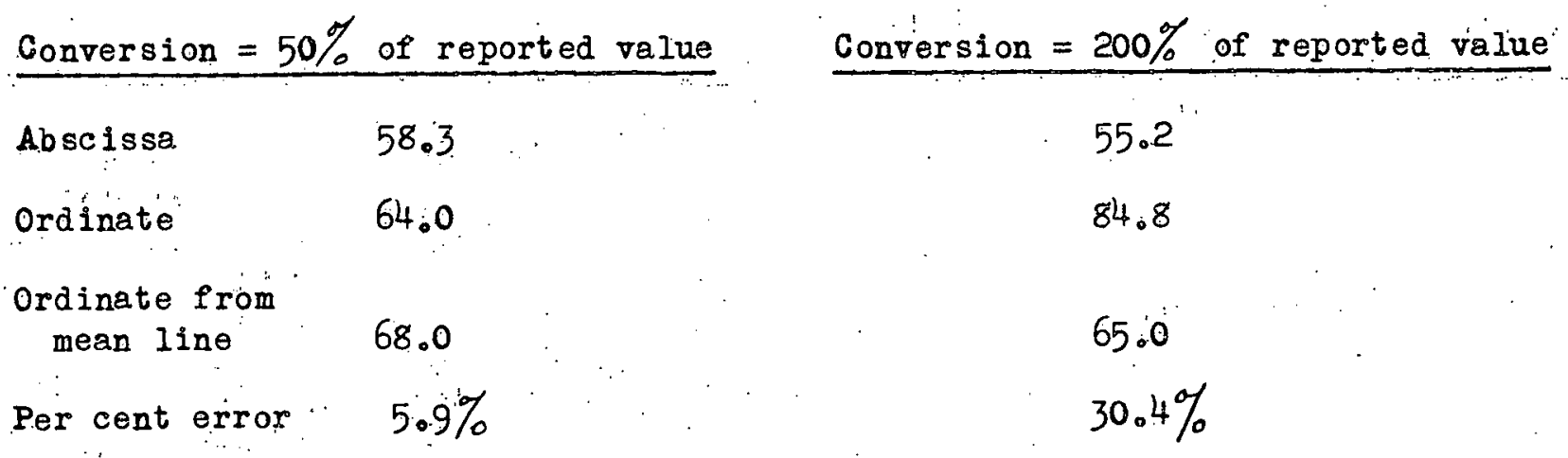

Run Number $36-$ Table 2

\begin{tabular}{|c|c|c|c|}
\hline & ordinate & Ab sc issa & $\begin{array}{l}\text { \% Error of Ordinate } \\
\text { Based on Mean Line }\end{array}$ \\
\hline Reported value & 12.0 & 2.1 & 0 \\
\hline $\begin{array}{l}\text { Conversion }=50 \% \text { of } \\
\text { reported value }\end{array}$ & 9.0 & $5.2^{\prime}$ & 40.0 \\
\hline $\begin{array}{l}\text { Conversion }=200 \% \text { of } \\
\text { reported value }\end{array}$ & 158 & -26.0 & (Iine extrapolated) \\
\hline
\end{tabular}

B. Wetted-Wall Absorption Unit

The following calculations show the method used to obtain a material balance and the removal efficiencies: (1) based on the enteringgas and exit-liquid analyses, and (2) based on the entering and exit gas analyses.

Bun $32-$ Table 4

Over-all equation $3 \mathrm{NO}_{2}+\mathrm{H}_{2} \mathrm{O} \longrightarrow 2 \mathrm{HNO}_{3}+\mathrm{NO}$

Temperatures: entering liquid - $860^{\circ}$

entering gas $-87^{\circ} \mathrm{F}$

exit. liquid $-86^{\circ}$ 要

exit gas $-92^{\circ} \mathrm{F}$ 
Entering $\mathrm{N}_{2}$ rate: $0.0775 \mathrm{lb} / \mathrm{min}$

Entering liquid: : distilled water

Fxit liquid rate: $250 \mathrm{cc} / \mathrm{min}$

Ent ering gas sample ( $\mathrm{H}_{2} \mathrm{O}_{2}$ in bottle):

Weight $=0.130 \mathrm{~g}$

Base used $=8.94 \mathrm{cc}$

Leaving gas sample ( $\mathrm{H}_{2} \mathrm{O}_{2}$ in bottle):

Woight $=0.134 \mathrm{~g}$

Rase used $=5.76 \mathrm{cc}$

Leaving gas sample ( $\mathrm{KMnO}_{4}$ and $\mathrm{H}_{2} \mathrm{SO}_{4}$ in bottle):

Weight $=0.150 \mathrm{~g}$

Net $\mathrm{Na}_{2} \mathrm{~S}_{2} \mathrm{O}_{3}$ us ised $=12.05 \mathrm{cc}$.

Exit liquid product:

Base used $=28.47 \mathrm{cc} / 10$ ce sample

Normality of base: 0.0237

Wormality of $\mathrm{Na}_{2} \mathrm{~S}_{2} \mathrm{O}_{3}: 0.0148$

\section{Entering}

Wt. fraction $\mathrm{eNO}_{2}=\frac{8.94 \times 0.0237 \times 46}{1000 \times 0.130}=(0.00163)(46)=0.0750$

Ib: $\mathrm{NO}_{2}$ entering per minute $=0.0775 \times 0.075 / 0.925=0.00628$

Mole per cent $e \mathrm{NO}_{2}=4.70$

\section{Leaving}

Only $2 / 3$ of the entering $\mathrm{NO}_{2}$ reacted is convered into nitric acid:

$\left(\mathrm{NO}_{2}\right.$ reacted $)=(3 / 2)\left(\mathrm{NO}_{2}\right.$ out in acid $)$

Lb $\mathrm{eNO}_{2}$. reacted per minute $=\frac{3 \times 28.47 \times 0.0237 \times 0.250 \times 46}{2 \times 10 \times 454}=0.002565$

$\frac{\mathrm{geq}\left(\mathrm{NO}+\mathrm{NNO}_{\mathrm{P}}\right) \text { out }}{\text { g sample }}=\frac{5.76 \times 0.0237}{1000 \times 0.134}=0.001019$

$\frac{\text { E eq (3NO }+ \text { eNO } 2) .0 u t ~}{g \text { sample }}=\frac{12.05 \times 0.0148}{1000 \times 0.150}=0.001189$ 
(NO $)=0.000085 \mathrm{~g}$ eq NO/g sample $=0.00255 \mathrm{~g}$ No $/ \mathrm{g}$. sample

$\left(\mathrm{eNO}_{2}\right)=0.000934 \mathrm{~g}$ eq $\mathrm{eNO}_{2} / \mathrm{g}$ sample $=0.0430 \mathrm{~g}$ eNO $2 / \mathrm{g}$ ? sample

$\left(\mathbb{N}_{2}\right)=0.954 \mathrm{~g} \quad \mathrm{~N}_{2} / \mathrm{g}$ sample $=0.03405 \mathrm{~g}$ eq $\mathrm{N}_{2} / \mathrm{g}$ sample

Mole per cent No $=0.24$

Mole per cent, eNO $2=2,66$

Total lb combined nitrogen as eNo 2 out $/ \mathrm{min}=\frac{0.0775 \times 0.043}{0.954}+0.002565=0.00606$

Total ib $\mathrm{eNO}_{2}$ in $/ \mathrm{min}=0.00628$

Per cent deriation $=3.5$.

(1) Removal efficiency based on entering gas and leaving liquid:

$$
\text { Bemoval efficiency }=\frac{2 \times 0.002565 \times 100}{3 \times 0.00628}=27.3 \%
$$

(2) Removal efficiency based on entering gas and leaving gas:

Removal ficiency $=\frac{2(0.00163-0.000934) 100}{3 \times 0.00163}=28.4 \%$

In the calculation of the efficiency based on the entering and leaving gas, the effect on the nitrogen concentiotion caused by the small oxide loss incurred while passing through the column has been neglected. The efficiency as calculated in (2) is slightly smaller than that which would have been calculated by not neglecting this ef fect and thas agrees more closely with the more precise value based on thei entering gas and leaving liquid.

C. Three-Plate Bubble-Gap Colum

The following calculations show the method used to obtain the efficiencies of each of the trays when all three trays were used for absorption: 
Ran $28-$ Table 7

Over-aII equation: $3 \mathrm{NO}_{2}+\mathrm{H}_{2} \mathrm{O} \longrightarrow 2 \mathrm{HNO}_{3}+\mathrm{NO}$

Pressures: $\mathrm{NO}_{2}$ eylinder $-2.0 \mathrm{~cm} \mathrm{Bg}$

Tower base $-8.0 \mathrm{~cm}$ abromonaphthalene

Tower top $\quad-4.3 \mathrm{~cm}$ a-bromonaphthalene

1. Temperatures: Entering liquid - $24.9^{\circ} \mathrm{C}$

Entering gas $-23.2^{\circ} \mathrm{C}$

Fixit. eas $\quad-26.4^{\circ} \mathrm{C}$

Entering air $\quad-25.0^{\circ} \mathrm{C}$

Entering air rate: : $1.21 \mathrm{ft} / \mathrm{min}$

- $0.00311 \mathrm{lb}$ moles/min

$-0.0904 \mathrm{lb} / \mathrm{min}$

Exit 11 quid rate $-296 \mathrm{cc} / \mathrm{min}$

lintering liquid composition - 0 wt per cent $\mathrm{HNO}_{3}$

Shtering gas composition - 2.1 mole per cent eNO 2

-3.30 wt per cent e $\mathrm{NO}_{2}{ }^{2}$

Total moles gas entering - $0.003181 \mathrm{~b}$ moles $/ \mathrm{min}$

Base used to titrate leaving liquid:

$$
\begin{aligned}
& \text { Bottom tray - } 1.231 \text { ce base/ec sample } \\
& \text { Middle tray }-0.589 \text { ce base/ce sample } \\
& \text { Toj tray - } 0.246 \text { ce base/ce sample }
\end{aligned}
$$

Normality of base -0.0493

Column diameter -7.5 inches

fin

Distance between plates - 12 Inches

At all timés, the reaction of $\mathrm{NNO}_{2}$ with water will be considered as going. 100 per cent to completion. The small loss of $\mathrm{NO}_{2}$ through the column is neglected in making partial pressure calculations and one mole of gas entering a tray is assumed as equivalent to one mole of gas leaving. the tray. 
Basis: I minute

\section{Bottom Tray}

Ib . $\mathrm{NO}_{2}$ ontering tray $=0.0904 \times 3.30 / 96.7=0.00308$

Lb. eNO 2 as acid formed on trày $=\frac{0.642 \times 0.0493 \times 296 \times 46}{1000 \times 454}=0.000949$ Since only.2/3 of the entering eNO $_{2}$ could have been absorbed and reacted to form $\mathrm{HNO}_{3}$.

Plate efficiency $=\frac{3 \times 0.000949 \times 100}{2 \times 0.00308}=46.2 \%$

Leaving bottom plate as gas.

$$
0.00308-0.000949 \times 3 / 2=0.00166 \mathrm{Ib} \mathrm{eNO}_{2} \text { unseacted }
$$

Since $1 / 2$ mole of No is formed for every mole of $\mathrm{HNO}_{3}$ formed;

$$
\frac{0.000949}{46 \times 2}=0.00001031 \mathrm{~b} \text { mole No formed }
$$

$$
-\mathrm{P}_{0_{2}}=0.21 \mathrm{~atm}
$$

Assuming I mole of gas into plat oquals 1 mole of gag leaving plate, $p_{\text {NO }}=0.0000103 / 0.00318=0.00324$ iinm.

According to Sherwood and Pigford (13), the amount of No which is oxidized to $\mathrm{NO}_{2}$ between plates of a bubbleccap absorber is given by

$$
\frac{1}{\left(p_{N O}\right)_{f}}=\frac{1}{\left(\bar{p}_{N O}\right)_{0}}+\left[2\left(p_{O_{2}}\right)_{0}-\left(p_{N O}\right)\right] \cdot \frac{k^{N} t}{2}
$$

where $\left(p_{N O}\right)_{P}=$ final partial pressure of NO, atm

$$
\begin{aligned}
& \left(\dot{p}_{\mathrm{HO}}\right)_{0}=\text { original partial pressure of NO atm } \\
& \left(\mathrm{p}_{\mathrm{O}_{2}}\right)_{Q}=\text { original partial pressure of } \mathrm{O}_{20} \text { atm } \\
& t=\text { contact time, sec } \\
& k^{80}=\text { a constant }=23.2(\mathrm{sec})^{-1} \text { (atm) }-2 \text { at operating temperature } \\
& t=\frac{0.307 \times 60 \times 1}{1.21}=15.3 \mathrm{sec}
\end{aligned}
$$




$$
\begin{aligned}
& \frac{1}{\left(\text { PMO }_{\mathrm{N}}\right)_{\mathrm{f}}}=\frac{1}{0.00324}+[2(0.21)-0.00324] \frac{23.2 \times 15.3}{2} \\
& \text { (pNo })_{1}=0.00261 \text { atr } \\
& \text { (PNo) converted }=0.00324-0.00261=0.00063 \text { atm } \\
& 0.00063 \times 0.00318 \times 46=0.0000921 \text { Ib eNO } 2 \text { sormed }
\end{aligned}
$$

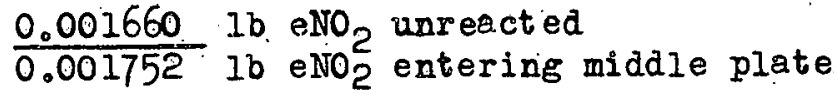

Middle Tray

Lb eNO 2 entering plate $=0.001752$

I.b $\mathrm{eNO}_{2}$ as acid formed on plate $=\frac{0.343 \times 0.0493 \times 296 \times 46}{1.000 \times 454}=0.000511$

Plate effieiency $=\frac{0.000511 \times 3 \times 100}{0.001752 \times 2}=43.6 \%$

$\frac{0.001752 \times 100}{46 \times 0.00318}=1.20$ mole per cent eNO 2 entering plate.

Ib eNO 2 leaving middle plate as gas.

$$
\begin{aligned}
& 0.001751-0.000511 \times 3 / 2=0.000991 \mathrm{~b} \mathrm{eNO} 2 \text { unreacted } \\
& \frac{0.000511}{46 \times 2}=0.000005551 \mathrm{~b} \text { moles No formed } \\
& \left(r_{N O}\right)_{0}=\frac{0.00000555}{0.00318}+0.00261=0.00436 \mathrm{~atm}
\end{aligned}
$$

Assuming oxygen cuncent ration unchanged.

$$
\begin{aligned}
& \frac{1}{\left(p_{\text {MO }}\right)_{f}}=\frac{1}{0.00436}+[2(0.21)-0.00436] \frac{23.2 \times 15.3}{2} \\
& \left(p_{\text {NO }}\right)_{f}=0.00330 \\
& \left(p_{\text {NO }}\right) \text { converted }=0.00106 \mathrm{~atm} \\
& 0.00106 \times 0.00318 \times 46=0.000155 \mathrm{Ib} \mathrm{eNO}_{2} \text { formed } \\
& 0.00092 \text { lb eNO2 unreacted } \\
& 0.00115 \text { ib eNO } 2 \text { entering top plate }
\end{aligned}
$$

Top Tray

$\mathrm{Lb}$ eNO 2 entering tray $=0.00115$

Ib $\theta \mathrm{NO}_{2}$ as acid formed on $t$ ray $=\frac{0.246 \times 0.0493 \times 296 \times 46}{1000 \times 454}$ 
Plate efficiency $=\frac{0.000364 \times 100 \times 3}{0.00115 \times 2}=47.5 \%$

$\frac{0.00115 \times 100}{46 \times 0.00318}=0.79$ mole per cent eNo 2 entering plate

$0.00115-0.000364 \times 3 / 2=0.00060 \mathrm{lb} \mathrm{NO}_{2}$ unreacted 
TABIDE 2

EXPERIMENAL DATA FOR ONE-PIATE BUBBIE-CAP COLUMN (SEe PABA I)

Total Pressure $=1$ Atmosphere

Mist Present

\begin{tabular}{|c|c|c|c|c|c|c|c|c|c|c|c|}
\hline \multirow[t]{2}{*}{$\begin{array}{l}\text { Run } \\
\text { No. }\end{array}$} & \multirow[t]{2}{*}{$\begin{array}{l}\text { Plate } \\
\text { Temp. } \\
{ }^{\circ}{ }_{C}\end{array}$} & \multirow{2}{*}{$\begin{array}{l}\text { Ent. } \\
\text { Liq. } \\
\text { Compn. } \\
\text { Wt }_{0} \% \\
\mathrm{HNO}_{3}\end{array}$} & \multirow{2}{*}{$\begin{array}{l}\text { Exit } \\
\text { Liq. } \\
\text { Rate } \\
\frac{\text { min }}{\text { min }}\end{array}$} & \multirow{2}{*}{$\begin{array}{l}\text { Exit } \\
\text { Liq. } \\
\text { Compn. } \\
\mathrm{Wt.}_{0} \% \\
\mathrm{HNO}_{3} \\
=10 \text { ? }\end{array}$} & \multirow{2}{*}{$\begin{array}{l}\text { Ent. } \\
\text { Gas } \\
\text { Bate } \\
\frac{1+3}{m i n}\end{array}$} & \multicolumn{3}{|c|}{$\begin{array}{c}\text { Entering Gas } \\
\text { Compno } \\
\text { Mole } \%\end{array}$} & \multicolumn{3}{|c|}{$\begin{array}{l}\text { Fxit Gais } \\
\text { Compn: } \\
\text { Mole \% }\end{array}$} \\
\hline & & & & & & $\begin{array}{c}\mathrm{NO}_{2} \\
+3 \\
2 \mathrm{~N}_{2} \mathrm{O}_{2}\end{array}$ & $\mathrm{NO}_{2}$ & $\begin{array}{l}\mathrm{N} 0 \\
244\end{array}$ & $\begin{array}{r}\mathrm{NO}_{2} \\
4 \\
\mathrm{HN}_{2} \mathrm{O}_{1}\end{array}$ & $\mathrm{NO}_{2}$ & $\mathrm{~N}_{2} \mathrm{O}_{4}$ \\
\hline $\begin{array}{l}1 \\
2 \\
3 \\
4 \\
5 \\
5 \\
7 \\
8 \\
9 \\
0\end{array}$ & $\begin{array}{l}19.8 \\
23.0 \\
18.2 \\
23.6 \\
19.4 \\
23.0 \\
21.1 \\
18.8 \\
18.4 \\
24.0\end{array}$ & $\begin{array}{l}0 \\
0 \\
0 \\
0 \\
0 \\
0 \\
0 \\
0 \\
0 \\
0\end{array}$ & $\begin{array}{l}292 \\
301 \\
298 \\
302 \\
286 \\
311 \\
304 \\
306 \\
306 \\
288\end{array}$ & $\begin{array}{l}0.615 \\
0.845 \\
0.900 \\
2.08 \\
1.84 \\
1.61 \\
1.81 \\
2.23 \\
2.16 \\
3.12\end{array}$ & $\begin{array}{l}1.222 \\
1.18 \\
1.21 \\
1.28 \\
1.21 \\
1.18 \\
1.21 \\
1.21 \\
1.21 \\
1.20\end{array}$ & $\begin{array}{l}0.454 \\
0.534 \\
0.622 \\
0.685 \\
0.699 \\
0.741 \\
0.794 \\
0.800 \\
0.821 \\
0.831\end{array}$ & $\begin{array}{l}0.420 \\
0.497 \\
0.554 \\
0.628 \\
0.622 \\
0.672 \\
0.707 \\
0.697 \\
0.710 \\
0.752\end{array}$ & $\begin{array}{l}0.0171 \\
0.0185 \\
0.0340 \\
0.0286 \\
0.0388 \\
0.0344 \\
0.0435 \\
0.0515 \\
0.0554 \\
0.0394\end{array}$ & $\begin{array}{l}0.482 \\
0.491 \\
0.578 \\
0.576 \\
0.611 \\
0.656 \\
0.696 \\
0.686 \\
0.714 \\
0.681\end{array}$ & $\begin{array}{l}0.392 \\
0.459 \\
0.518 \\
0.534 \\
0.550 \\
0.602 \\
0.627 \\
0.608 \\
0.628 \\
0.626\end{array}$ & $\begin{array}{l}0.0150 \\
0.0159 \\
0.0298 \\
0.0206 \\
0.0306 \\
0.0272 \\
0.0347 \\
0.0393 \\
0.0430 \\
0.0276\end{array}$ \\
\hline $\begin{array}{l}\frac{3}{2} \\
3 \\
4 \\
5 \\
6\end{array}$ & $\begin{array}{l}19.6 \\
23.6 \\
20.2 \\
20.0 . \\
22.2 \\
21.3 \\
19.4 \\
18.2 \\
23.2 \\
21.0\end{array}$ & $\begin{array}{l}0 \\
0 \\
0 \\
0 \\
0 \\
0 \\
0 \\
0 \\
0 \\
0\end{array}$ & $\begin{array}{l}284 \\
291 \\
292 \\
295 \\
278 \\
307 \\
296 \\
300 \\
284 \\
293\end{array}$ & $\begin{array}{l}2.78 \\
3.77 \\
2.78 \\
3.91 \\
2.99 \\
3.06 \\
4.71 \\
4.52 \\
4.75 \\
3.62\end{array}$ & $\begin{array}{l}1.21 \\
1.20 \\
1.22 \\
1.21 \\
1.18 \\
1.21 \\
1.23 . \\
1.22 \\
1.20 \\
1.16\end{array}$ & $\begin{array}{l}0.837 \\
0.887 \\
0.900 \\
0.914 \\
0.925 \\
0.965 \\
1.08 \\
1.12 \\
1.12 \\
1.15\end{array}$ & $\begin{array}{l}0.731 \\
0.795 \\
0.784 \\
0.793 \\
0.817 \\
0.842 \\
0.912 \\
0.928 \\
0.978 \\
0.970\end{array}$ & $\begin{array}{l}0.0529 \\
0.0458 \\
0.0580 \\
0.0604 \\
0.0540 \\
0.0615 \\
0.084 \\
0.096 \\
0.071 \\
0.090\end{array}$ & $\begin{array}{l}0.706 \\
0.704 \\
0.774 \\
0.720 \\
0.781 \\
0.805 \\
0.850 \\
0.901 \\
0.892 \\
0.970\end{array}$ & $\begin{array}{l}0.627 \\
0.644 \\
0.685 \\
0.640 \\
0.702 \\
0.716 \\
0.740 \\
0.763 \\
0.798 \\
0.840\end{array}$ & $\begin{array}{l}0.0394 \\
0.0302 \\
0.0444 \\
0.0400 \\
0.0595 \\
0.0445 \\
0.055 \\
0.066 \\
0.047 \\
0.065\end{array}$ \\
\hline $\begin{array}{l}23 \\
24 \\
25 \\
26 \\
26 \\
27 \\
28\end{array}$ & $\begin{array}{l}19.4 \\
21.5 \\
22.2 \\
23.2 \\
21.1 \\
19.4 \\
21.9 \\
23.0 \\
25.0 \\
22.5\end{array}$ & $\begin{array}{l}0 \\
0 \\
0 \\
0 . \\
0 \\
0 \\
0 \\
0 \\
0 \\
0\end{array}$ & $\begin{array}{l}297 \\
289 \\
296 \\
301 \\
296 \\
299 \\
292 \\
309 \\
298 \\
301\end{array}$ & $\begin{array}{l}5.90 \\
6.11 \\
7.00 \\
7.20 \\
7.25 \\
7.05 \\
9.10 \\
7.00 \\
14.4 \\
25.8\end{array}$ & $\begin{array}{l}1.22 \\
1.22 \\
1.22 \\
1.21 \\
1.22 \\
1.23 \\
1.22 \\
1.14 \\
1.15 \\
1.49\end{array}$ & $\begin{array}{l}1.19 \\
1.33 \\
1.42 \\
1.44 . \\
1.47 \\
1.63 \\
1.64 \\
1.70 \\
2.70 \\
3.46\end{array}$ & $\begin{array}{l}0.992 \\
1.118 \\
1.192 \\
1.222 \\
1.212 \\
1.292 \\
1.34 \\
1.40 \\
2.10 \\
2.50\end{array}$ & $\begin{array}{l}0.099 \\
0.106 \\
0.114 \\
0.109 \\
0.129 \\
0.169 \\
0.148 \\
0.15 \\
0.30 \\
0.48\end{array}$ & $\begin{array}{l}0.901 \\
1.040 \\
1.080 \\
1.080 \\
1.12 \\
1.24 \\
1.20 \\
1.32 \\
1.96 \\
2.75\end{array}$ & $\begin{array}{l}0.779 \\
0.904 \\
0.938 \\
0.948 \\
0.958 \\
1.026 \\
1.026 \\
1.12 \\
1.62 \\
1.70\end{array}$ & $\begin{array}{l}0.061 \\
0.068 \\
0.071 \\
0.066 \\
0.081 \\
0.107 \\
0.087 \\
0.100 \\
0.172 \\
0.225\end{array}$ \\
\hline
\end{tabular}


TABLT 2 (continued)

\begin{tabular}{|c|c|c|c|c|c|c|c|c|c|c|}
\hline \multirow[t]{2}{*}{$\begin{array}{l}\text { Run } \\
\text { No. }\end{array}$} & \multirow{2}{*}{$\begin{array}{l}\text { Plate } \\
\text { Temp. } \\
\text { oC }\end{array}$} & \multirow{2}{*}{$\begin{array}{l}\text { Ent. } \\
\text { Liq. } \\
\text { Compn. } \\
\text { wt .\%० } \\
\text { HNO }_{3}\end{array}$} & \multirow{2}{*}{$\begin{array}{l}\text { Exit } \\
\text { Liq. } \\
\text { Bate } \\
\frac{\text { ce }}{\min }\end{array}$} & \multirow{2}{*}{$\begin{array}{l}\text { Exit. } \\
\text { Liq. } \\
\text { Compn. } \\
\text { Ht.\%o } \\
\text { HNo } 3 \\
x \quad 102 \\
\end{array}$} & \multirow{2}{*}{$\begin{array}{l}\text { Ent. } \\
\text { Gas } \\
\text { Bate } \\
\text { pis } \\
\text { min }\end{array}$} & \multicolumn{2}{|c|}{$\begin{array}{c}\text { Enteroing Gas } \\
\text { Compno } \\
\text { Mole } \%\end{array}$} & \multicolumn{3}{|c|}{$\begin{array}{l}\text { Exit Gas } \\
\text { Compn } \\
\text { Mole } \%\end{array}$} \\
\hline & & & & & & $\begin{array}{r}\mathrm{NO}_{2} \\
+\mathrm{t}_{2} \\
2 \mathrm{~N}_{4} \\
\end{array}$ & $\mathrm{NO}_{2} \quad \mathrm{~N}_{2} \mathrm{O}_{4}$ & $\begin{array}{c}\mathrm{NO}_{2} \\
+ \\
2 \mathrm{~N}_{2} \mathrm{O}_{4}\end{array}$ & $\mathrm{NO}_{2}$ & $\mathrm{~N}_{2} \mathrm{O}_{4}$ \\
\hline $\begin{array}{l}31 \\
32 \\
33 \\
34 \\
35 \\
36 \\
37 \\
38 \\
39 \\
40\end{array}$ & $\begin{array}{l}22.5 \\
22.0 \\
21.5 \\
24.0 \\
21.5 \\
23.0 \\
23.0 \\
20.0 \\
26.0 \\
20.5\end{array}$ & $\begin{array}{l}0 \\
0 \\
0 \\
0 \\
0 \\
0 \\
0 \\
0 \\
0 \\
0\end{array}$ & $\begin{array}{l}291 \\
302 \\
303 \\
307 \\
306 \\
304: \\
300 \\
299 \\
305 \\
610\end{array}$ & $\begin{array}{r}33.7 \\
39.0 \\
59.3 \\
73.0 \\
75.4 \\
84.1 \\
87.8 \\
105.0 \\
116.4 \\
4.8\end{array}$ & $\begin{array}{l}1.19 \\
1.22 \\
1.24 \\
1.21 \\
1.21 \\
1.20 \\
1.20 \\
1.23 \\
1.24 \\
1.18\end{array}$ & $\begin{array}{l}4.31 \\
4.62 \\
6.71 \\
8.98 \\
8.14 \\
8.70 \\
8.73 \\
10.2 \\
11.6 \\
11.077\end{array}$ & 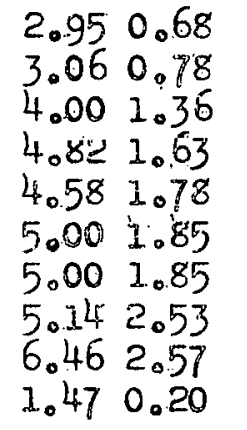 & $\begin{array}{l}2.55 \\
2.62 \\
3.79 \\
4.35 \\
4.56 \\
4.47 \\
4.35 \\
5.07 \\
5.85 \\
1.37\end{array}$ & $\begin{array}{l}2.01 \\
1.098 \\
2.61 \\
3.05 \\
3.00 \\
3.07 \\
3.00 \\
3.15 \\
3.95 \\
1.13\end{array}$ & $\begin{array}{l}0.32 \\
0.32 \\
0.59 \\
0.65 \\
0.78 \\
0.70 \\
0.68 \\
0.96 \\
0.95 \\
0.12\end{array}$ \\
\hline $\begin{array}{l}41 \\
42 \\
43 \\
44 \\
45 \\
46 \\
47 \\
48 \\
49\end{array}$ & $\begin{array}{l}22.0 \\
22.5 \\
18.0 \\
23.0 \\
23.0 \\
23.5 \\
23.5 \\
25.0 \\
25.0 \\
20.0\end{array}$ & $\begin{array}{l}0 \\
0 \\
0 \\
15 \\
15 \\
15 \\
15 \\
15 \\
15 \\
0\end{array}$ & $\begin{array}{l}608 \\
605 \\
595 \\
284 \\
290 \\
288 \\
289 \\
282 \\
292 \\
318\end{array}$ & $\begin{array}{l}25.2 \\
47.7 \\
54.1 \\
18.0^{7} \\
18.8^{4} \\
22.1^{7} \\
53.3^{4} \\
72.7^{4} \\
96.2^{4} \\
3.8\end{array}$ & $\begin{array}{l}1.23 \\
1.22 \\
1.23 \\
1.19 \\
1.19 \\
1.19 \\
1.017 \\
1.18 \\
1.22 \\
2.26\end{array}$ & $\begin{array}{l}5.88 \\
9.54 \\
9.92 \\
2.47 \\
2.70 \\
2.71 \\
5.85 \\
7.41 \\
9.71 \\
1.10\end{array}$ & 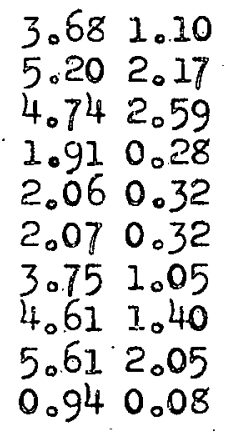 & $\begin{array}{l}3.40 \\
4.79 \\
4.64 \\
1.61 \\
1.78 \\
1.63 \\
3.21 \\
3.90 \\
5.08 \\
0.099\end{array}$ & $\begin{array}{l}2.42 \\
3.19 \\
2.82 \\
1.34 \\
1.46 \\
1.36 \\
2.40 \\
2.84 \\
3.50 \\
0.85\end{array}$ & $\begin{array}{l}0.49 \\
0.80 \\
0.91 \\
0.1 .35 \\
0.160 \\
0.135 \\
0.415 \\
0.53 \\
0.079 \\
0.07\end{array}$ \\
\hline $\begin{array}{l}.51 \\
.52 \\
53 \\
.54 \\
55\end{array}$ & $\begin{array}{l}20.0 \\
21.0 \\
20.0 \\
20.5 \\
22.0 \\
26.5 \\
22.5 \\
22.0 \\
23.0 \\
19.0\end{array}$ & $\begin{array}{l}0 \\
0 \\
0 \\
0 \\
0 \\
0 \\
0 \\
0 \\
0 \\
0\end{array}$ & $\begin{array}{l}280 \\
315 \\
305 \\
296 \\
290 \\
290 \\
280 \\
320 \\
299 \\
290\end{array}$ & $\begin{array}{r}6.5 \\
18.5 \\
29.0 \\
30.6 \\
57.0 \\
60.1 \\
91.5 \\
108.0 \\
157.0 \\
123.0\end{array}$ & $\begin{array}{l}2.11 \\
2.26 \\
2.30 \\
2.37 \\
2.045 \\
2.43 \\
2.46 \\
2.36 \\
2.43 \\
2.44\end{array}$ & $\begin{array}{l}1.25 \\
2.80 \\
2.90 \\
3.05 \\
4.63 \\
4.74 \\
6.05 \\
7.80 \\
9.48 \\
9.05\end{array}$ & 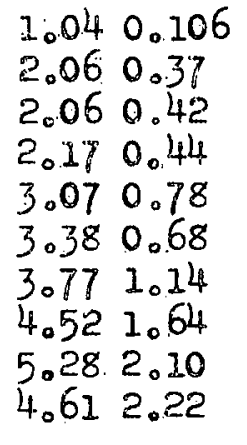 & $\begin{array}{l}1.08 \\
2.28 \\
2.15 \\
2.28 \\
3.25 \\
3.27 \\
3.90 \\
5.38 \\
5.59 \\
6.20\end{array}$ & $\begin{array}{l}0.92 \\
1.74 \\
1.63 \\
1.72 \\
2.35 \\
2.51 \\
2.72 \\
3.46 \\
3.63 \\
3.56\end{array}$ & $\begin{array}{l}0.08 \\
0.27 \\
0.26 \\
0.28 \\
0.45 \\
0.38 \\
0.59 \\
0.96 \\
0.98 \\
1.32\end{array}$ \\
\hline 51 & $\begin{array}{l}25.0 \\
29.0 \\
26.0 \\
27.5\end{array}$ & $\begin{array}{l}0 \\
0 \\
0 \\
0\end{array}$ & $\begin{array}{l}330 \\
290 \\
290 \\
290\end{array}$ & $\begin{array}{l}128.0 \\
160.0 \\
173.0 \\
170.0\end{array}$ & $\begin{array}{l}2.61 \\
2.60 \\
2.68 \\
2.67\end{array}$ & $\begin{array}{r}9.68 \\
9.82 \\
9.82 \\
10.44\end{array}$ & $\begin{array}{ll}5.60 & 2.04 \\
6.10 & 1.86 \\
5.78 & 2.02 \\
6.22 & 2.11\end{array}$ & $\begin{array}{l}6.40 \\
6.25 \\
6.20 \\
6.77\end{array}$ & $\begin{array}{l}4.16 \\
4.35 \\
4.14 \\
4.51\end{array}$ & $\begin{array}{l}1.12 \\
0.95 \\
1.03 \\
1.13\end{array}$ \\
\hline
\end{tabular}

Increase over 15 weight per cent. 


\section{TABIS 374}

\section{EXPEHIMENTAL DATA USING DISTILUAD WATER AND}

AQUEOUS NaCI AS ABSORBEMTS IN WETTED-WALI JOLIMN

(Stuciy on Vapor and Iiquid Phase Reactions between Nitrogen Dioxide and Water - See Part II)

Total Pressure = I Atmosphere

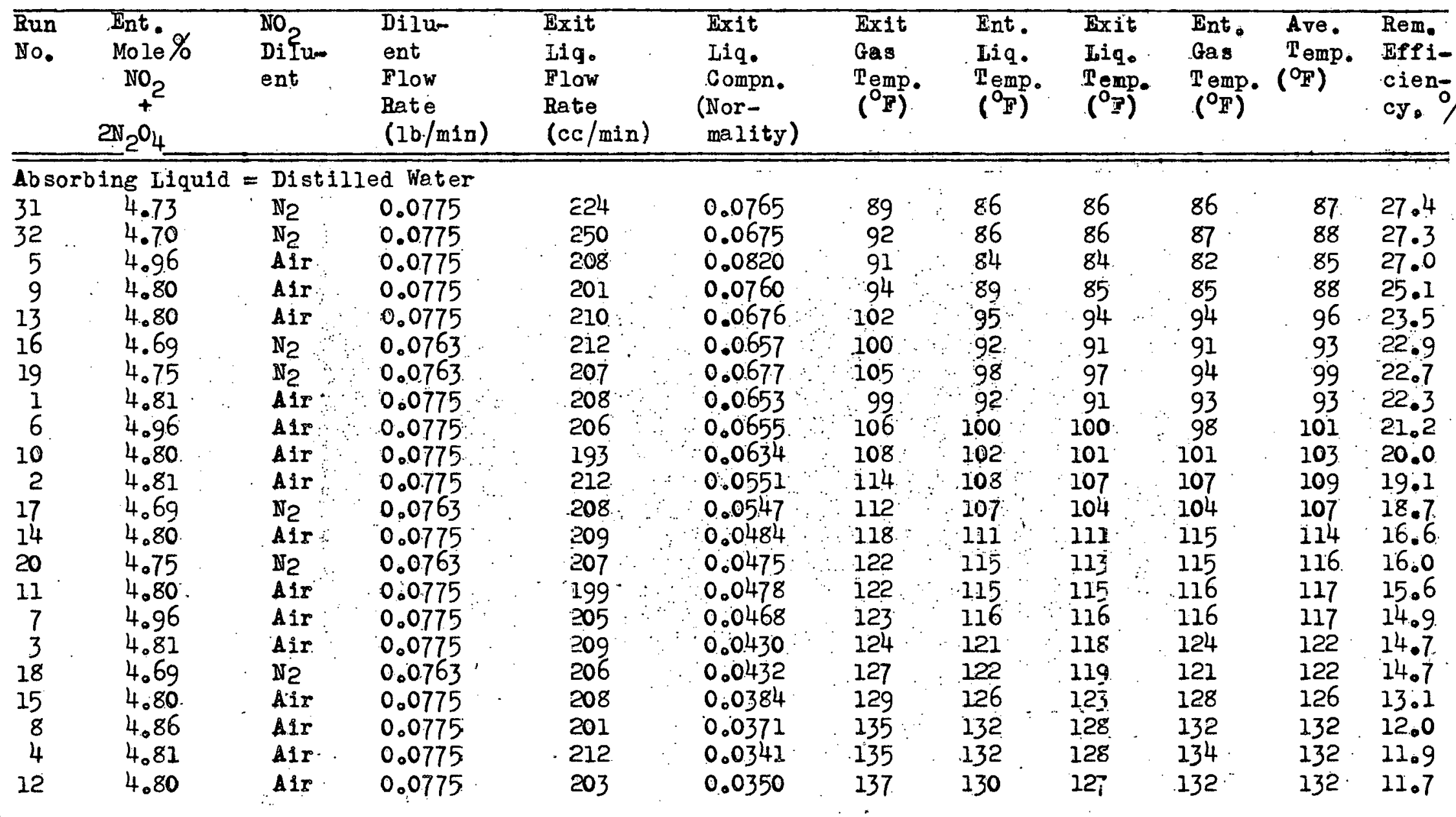


TABLE 3 (Continued)

\begin{tabular}{|c|c|c|c|c|c|c|c|c|c|c|c|}
\hline $\begin{array}{l}\text { Tun } \\
\text { No. }\end{array}$ & $\begin{array}{l}\text { Bnt } \\
\text { Mole } \% \\
\mathrm{NO}_{2} \\
+ \\
2 \mathrm{~N}_{2} \mathrm{O}_{4}\end{array}$ & $\begin{array}{l}\mathrm{NO}_{2} \\
\mathrm{Di}^{\mathrm{I}} \mathrm{Iu}- \\
\text { ent }\end{array}$ & $\begin{array}{l}\text { Dilu- } \\
\text { ent } \\
\text { Flow } \\
\text { Rate } \\
\text { (lb/min) }\end{array}$ & $\begin{array}{l}\text { Buxit } \\
\text { Iiq. } \\
\text { FIow } \\
\text { Rate } \\
\text { (cc/min) }\end{array}$ & $\begin{array}{l}\text { Rxis } \\
\text { Iiq. } \\
\text { Compn. } \\
\text { (Nor- } \\
\text { mality) }\end{array}$ & $\begin{array}{l}\text { Exit: } \\
\text { Gas } \\
\text { Temp. } \\
\left.\left({ }^{\circ}\right)^{\circ}\right)\end{array}$ & $\begin{array}{l}\text { Ent. } \\
\text { Liq. } \\
\text { Temp. }_{\text {emp }} \\
\left({ }^{\circ}\right)\end{array}$ & $\begin{array}{l}\text { Exit } \\
\text { Liq. } \\
\text { Temp. } \\
\text { (OF) }\end{array}$ & $\begin{array}{l}\text { Ent. } \\
\text { Gas } \\
\text { Temp. } \\
\text { ( }{ }^{\circ} \text { F) }\end{array}$ & $\begin{array}{l}\text { Ave. } \\
\text { Temp. } \\
\left({ }^{\circ} \mathrm{F}\right)\end{array}$ & $\begin{array}{l}\text { Rem: } \\
\text { RPP1- } \\
\text { cien- } \\
\text { cy, } \%\end{array}$ \\
\hline
\end{tabular}

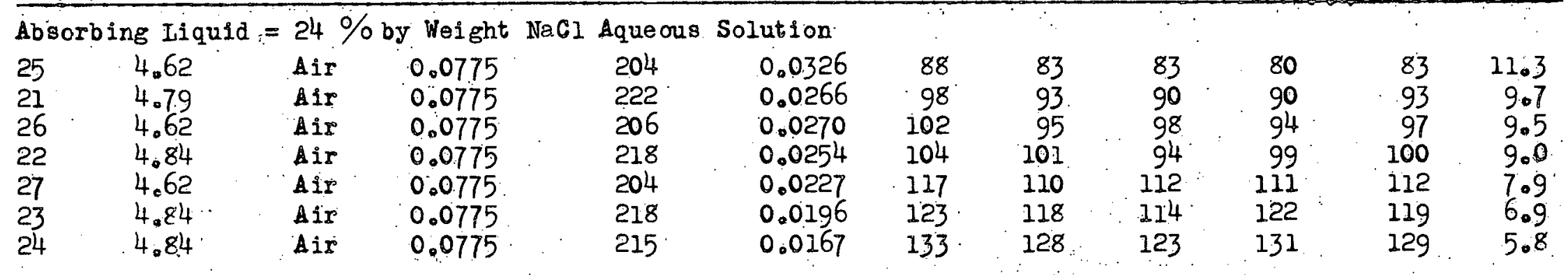




\section{TABID 476}

BXPERIMENTAL DATA FOR RUNS IN WHICH EXIT GAS FROM WETTED-UALL COLEMN WAS ANALYZED

(Study on Vapor and Liquid Phase Reactions between Nitrogen Dioxide anc Water - See Part II)

Total Pres sure = 1 Atmosphere

$\mathrm{NO}_{2}$ Diluent $=\mathrm{N}_{2}$

\begin{tabular}{|c|c|c|c|c|c|c|c|c|c|c|c|c|}
\hline $\begin{array}{l}\text { Run } \\
\text { No. }\end{array}$ & $\begin{array}{l}\text { Diluent } \\
\text { Flow } \\
\text { Rate } \\
\text { (1b/min) }\end{array}$ & $\begin{array}{l}\text { Ent: } \\
\text { Molé } \\
\text { Per } \\
\text { Cent } \\
\text { eNO }_{2}\end{array}$ & $\begin{array}{l}\text { Exit } \\
\text { Mole } \\
\text { Per } \\
\text { Cent } \\
\text { eNO }\end{array}$ & $\begin{array}{l}\text { Exit } \\
\text { Mole } \\
\text { Pex } \\
\text { Cent } \\
\text { No }\end{array}$ & $\begin{array}{l}\text { ixit } \\
\text { Liq. } \\
\text { Flow } \\
\text { 3ate } \\
(\mathrm{cc} / \mathrm{min})\end{array}$ & $\begin{array}{l}\text { Exit } \\
\text { Gas } \\
\text { Temp. } \\
\left({ }^{O} \text { T }\right)\end{array}$ & $\begin{array}{l}\text { Bnt. } \\
\text { ulq. } \\
\text { Temp. } \\
\left({ }^{\circ} \mathrm{p}\right)\end{array}$ & $\begin{array}{l}\text { Exit } \\
\text { Liq. } \\
\text { Temp. } \\
\left({ }^{0} F\right)\end{array}$ & $\begin{array}{l}\text { Ent. } \\
\text { Gas } \\
\text { Temp. } \\
\left(O_{F}\right)\end{array}$ & $\begin{array}{l}\text { Ave. } \\
\text { Temp. } \\
\text { (OF) }\end{array}$ & $\begin{array}{l}\text { Rem. } \\
\text { Ref. } \\
\text { Based } \\
\text { on Gas } \\
\text { Samples } \\
\text { per cent }\end{array}$ & $\begin{array}{l}\text { Removal } \\
\text { Eif. Based } \\
\text { on Ent. Gas } \\
\text { and Ivg. Iiq. } \\
\text { Samples } \\
\text { per cent. }\end{array}$ \\
\hline
\end{tabular}

Absorbing Liquid = Distilled Water. Diluent $=\mathbb{N}_{2}$.

$\begin{array}{lllllllllllll}31 & 0.0775 & 4.7 .3 & 2.61 & 0.21 & 224 & 89 & 86 & 86 & 86 & 87 & 29.4 & 27.4 .\end{array}$

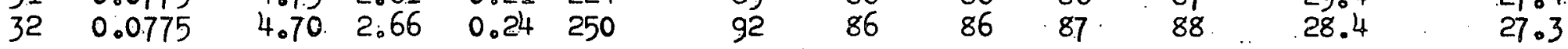

Absorbing Liquid $=20 \%$ by Weight Na. H Aqueous Solution. Diluent $=\mathbb{N}_{2}$.

\begin{tabular}{|c|c|c|c|c|c|c|c|c|c|c|}
\hline $\begin{array}{l}0.0775 \\
0.0728 \\
0.0775\end{array}$ & $\begin{array}{l}4.80 \\
4.26 \\
4.75\end{array}$ & $\begin{array}{l}2.90 \\
2.90 \\
3.98\end{array}$ & $\begin{array}{l}0.48 \\
0.53 \\
0.05\end{array}$ & $\begin{array}{l}205 \\
200 \\
199\end{array}$ & $\begin{array}{r}89 \\
98 \\
118\end{array}$ & $\begin{array}{r}87 \\
98 \\
114\end{array}$ & $\begin{array}{r}87 \\
98 \\
114\end{array}$ & $\begin{array}{r}8 \\
9 \\
11\end{array}$ & $\begin{array}{r}88 \\
98 \\
115 .\end{array}$ & $\begin{array}{l}25.7 \\
20.7 \\
11.8\end{array}$ \\
\hline
\end{tabular}


TABLE 5

BXXERIMENTAL DATA FOR REGOVERY OF NITROGEN DIOXIDE

WITH VENTURI ATOMI ZER (See PaTE III)

Gas Velocity at Venturi Throat $=300 \mathrm{ft} / \mathrm{sec}$

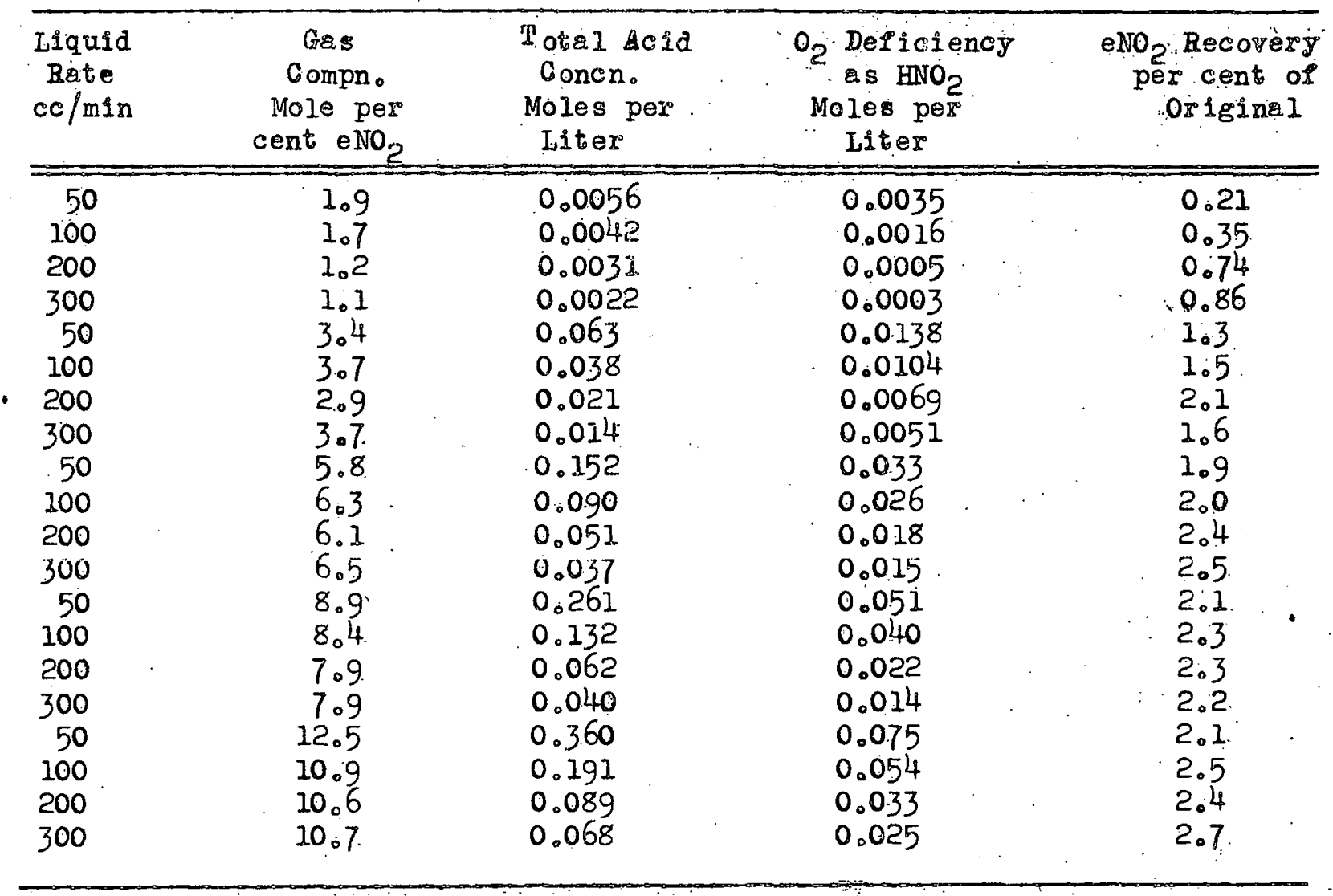


TABIE 6

FXPERIMENTAL DATA FOR RECOVERY OF NITROGEN DIOXIDE WITH FRITTED-GIASS DISPERSER (See Part III)

Gas Rate $=0.05 \mathrm{ft} 3 / \mathrm{min}$

Pwo-Hoưr Run

Inttial Gos

Cumpusition

M. F。 $\mathrm{NNO}_{2}$

Moles $\mathrm{NO}_{2}$
Recovered Unreacted

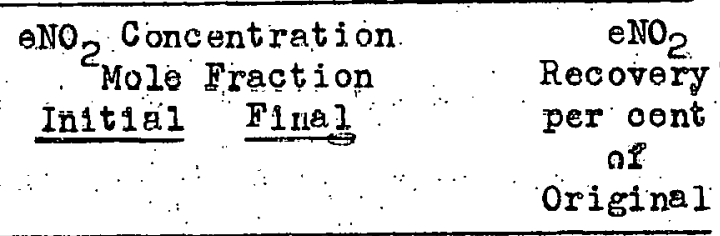

0.038

0.090

0.112

0.172

0.207

0.248

0.347

0.380

0.484

0.591

0.682

0.0063
0.0133
0.0154
0.0220
0.0253
0.0293
0.0385
0.0405
0.0495
0.0575
0.0635

0.00160

0.00248

0.00217

0.00356

0.00356

0.00415

0.00576

0.00530

0.00826 :

0.00942

0.0096
75.6

82.1

86.9

86.5

88.5

88.5

88.6 .

90.5

88.5

89.5

90.6 . 
TABLE 7

RXPERIMENTAL DATA FOR THREE-PIATE BUBBIE-GAP COLUMN WITH:

No MIST (See Part 'V)

Total Pressure $=1$ Atmosphere

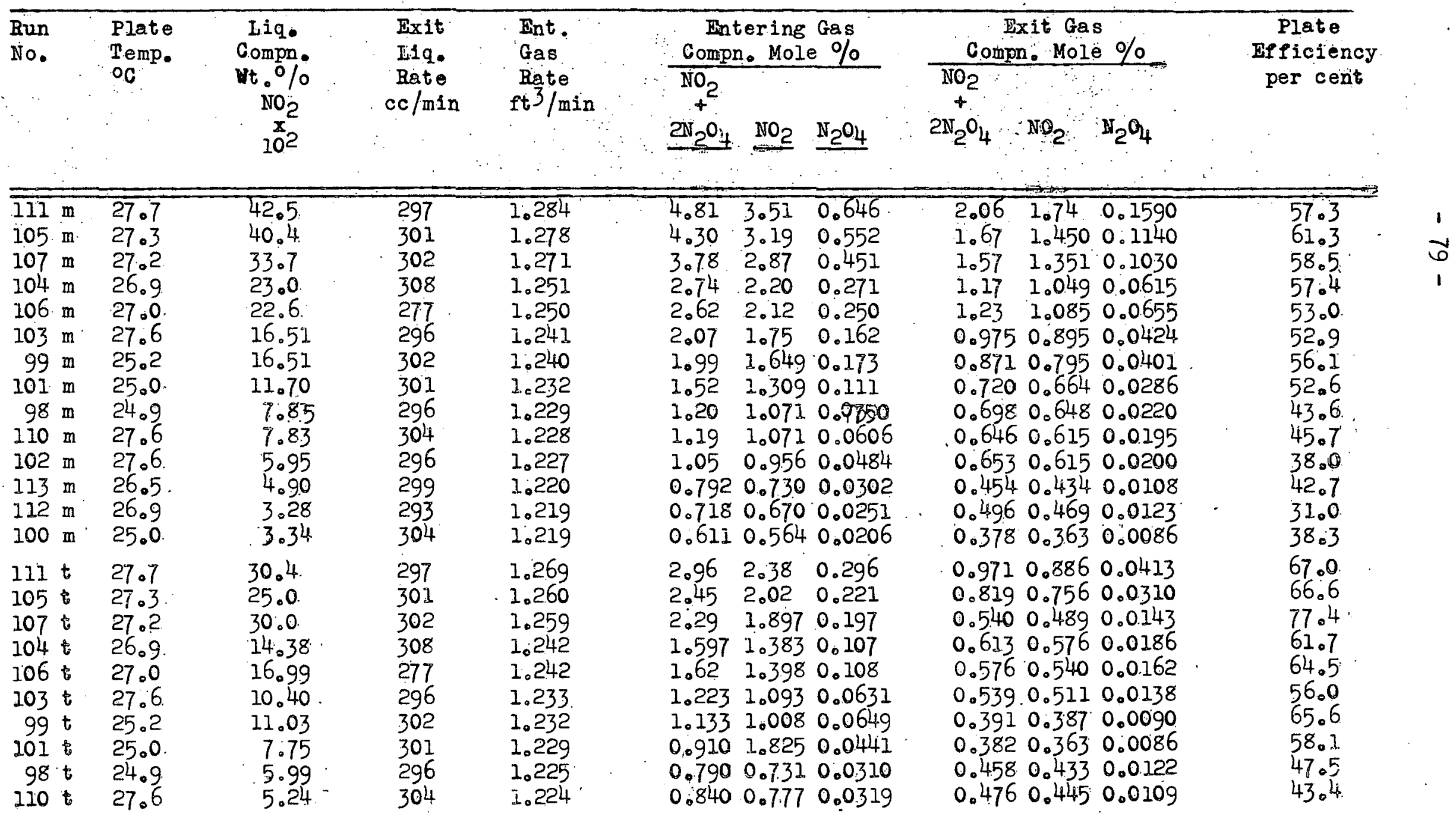


TABLE 7 (Cont inued) 80

\begin{tabular}{|c|c|c|c|c|c|c|c|}
\hline $\begin{array}{l}\text { Kun } \\
\text { No. }\end{array}$ & $\begin{array}{l}\text { plote } \\
\text { Temp. } \\
{ }^{\circ} \mathrm{C}\end{array}$ & $\begin{array}{l}\text { Iiq. } \\
\text { Compn. } \\
\text { wt } \% \\
\text { No\% } \\
x \quad 102\end{array}$ & $\begin{array}{l}\text { Fxit } \\
\text { Iiq. } \\
\text { Räe } \\
\text { cc/min }\end{array}$ & $\begin{array}{l}\text { Ento } \\
\text { gas } \\
\text { Raje } \\
\text { et } 3 \text { /min }\end{array}$ & $\begin{array}{l}\text { Intering Gas } \\
\text { Compn. Mole \% } \\
\mathrm{NO}_{2} \\
{ }^{+} \\
\mathrm{N}_{2} \mathrm{O}_{4} \quad \mathrm{NO}_{2} \quad \mathrm{~N}_{2} \mathrm{O}_{4}\end{array}$ & $\begin{array}{l}\text { Exit Gas } \\
\text { Compn. Mole } \% \\
\mathrm{NO}_{2} \\
+\mathrm{N}_{2} \\
2 \mathrm{~N}_{4} \quad \mathrm{NO}_{2} \quad \mathrm{~N}_{2} \mathrm{O}_{4}\end{array}$ & $\begin{array}{l}\text { Plate } \\
\text { Efficlency } \\
\text { per cent }\end{array}$ \\
\hline
\end{tabular}

\begin{tabular}{lllllllll}
$102+$ & 27.6 & 4.16 & 296 & 1.223 & 0.7290 .6730 .0239 & 0.439 .0 .4210 .0094 & 38.9 \\
$113 t$ & 26.5 & 3.42 & 299 & 1.220 & 0.4960 .4640 .0 .127 & 0.2620 .2600 .0037 & 47.3 \\
$112 t$ & 26.9 & 2.59 & 293 & 1.219 & 0.5190 .4910 .0135 & 0.3420 .3350 .0063 \\
$100 \mathrm{t}$ & 25.0 & 2.46 & 304 & 1.219 & 0.4030 .382 .0 .0095 & 0.2320 .2280 .0034 & 34.0 \\
\hline
\end{tabular}

m réfers to middle tray

$t$ refers to top tray

For additional data see Reference (2) 


\section{1}

TAEIS 8

DXPURIMENTAL DATA FOR THREE-PIAIPE BUBBLE-CAP COLUMN WITH MIST

(See Part V)

Toṭai Pressur $z=1$ Atmosphere

\begin{tabular}{|c|c|c|c|c|c|c|c|}
\hline $\begin{array}{l}\text { Bun } \\
\text { No. }\end{array}$ & $\begin{array}{l}\text { Plate } \\
\text { Temp. } \\
{ }^{\circ} \mathrm{C}\end{array}$ & $\begin{array}{l}\text { Liq. } \\
\text { Concn. } \\
\text { Wt. } \% \\
\mathrm{NO}_{2} \\
\times 10^{2}\end{array}$ & $\begin{array}{l}\text { Bxit } \\
\text { Liq. } \\
\text { Bate } \\
\mathrm{cc} / \mathrm{min}\end{array}$ & $\begin{array}{l}\text { Ent. } \\
\text { Gas } \\
\text { Rate } \\
\text { ft } 3 / \mathrm{min}\end{array}$ & 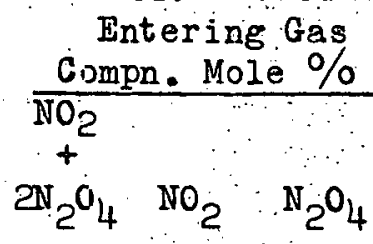 & 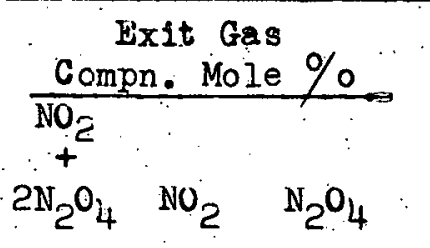 & $\begin{array}{l}\text { Plate } \\
\text { Pfficiency } \\
\text { per cent }\end{array}$ \\
\hline
\end{tabular}

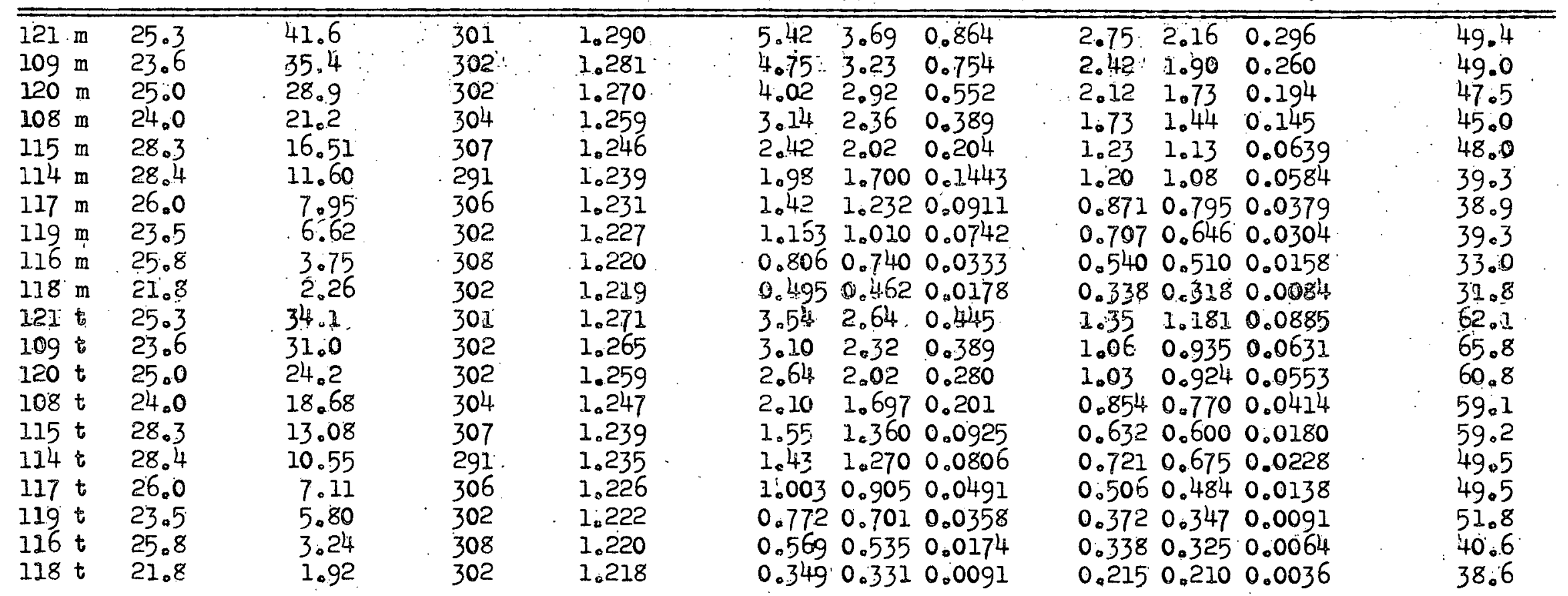

m refers to midale tray

$t$ refers to top trap

For additional data, see Reference (2) 


\section{$-82-$}

TABID 9

EXPERIMENTAL DATA FOR CAUSTIC ABSORPIION OF NITROGEN OXIDES (See Part VI)

Three-Plate Bubble-Cap Tower

Total Pressure = I Atmosphere

Mist Present

\begin{tabular}{|c|c|c|c|c|c|c|c|}
\hline $\begin{array}{l}\overline{\text { Run }} \\
\mathrm{N} \cap .\end{array}$ & $\begin{array}{c}\text { Air } \\
T_{e m p} \\
O_{F}\end{array}$ & $\begin{array}{l}\text { Ent o Liq. } \\
\text { Compn. } \\
\text { Wt por cent } \\
\text { Canstic } \\
\end{array}$ & $\begin{array}{c}\text { Exit } \\
\text { Liquid } \\
\text { Rate } \\
\text { ce./min } \\
\end{array}$ & $\begin{array}{c}\text { Moles eNO} \\
\text { per Mino } \\
\text { Lvg. in } \\
\text { Liguid } \\
\end{array}$ & $\begin{array}{l}\text { Gas Rate } \\
P t 3 / \mathrm{min}\end{array}$ & $\begin{array}{l}\text { Mole \%o } \\
\text { oNO2 } \\
\text { Entering }\end{array}$ & $\begin{array}{l}\text { Remoré } \\
\text { Eff. } \\
\text { per cen }\end{array}$ \\
\hline $\begin{array}{r}90 \\
100 \\
110 \\
120 \\
130\end{array}$ & $\begin{array}{l}83 \\
76 \\
76 \\
76 \\
76\end{array}$ & $\begin{array}{l}1 \\
1 \\
1 \\
1 \\
1\end{array}$ & $\begin{array}{l}320 \\
319 \\
323 \\
324 \\
318\end{array}$ & $\begin{array}{l}0.104 \\
0.0764 \\
0.0597 \\
0.0443 \\
0.0345\end{array}$ & $\begin{array}{l}1.19 \\
1.19 \\
1.19 \\
1.19 \\
1.19\end{array}$ & $\begin{array}{l}8.00 \\
6.14 \\
5.00 \\
4.02 \\
3.25\end{array}$ & $\begin{array}{l}86.2 \\
84.0 \\
81.8 \\
76.2 \\
74.0\end{array}$ \\
\hline $\begin{array}{l}140 \\
150 \\
160 \\
170 \\
180\end{array}$ & $\begin{array}{l}82 \\
82 \\
81 \\
81 \\
81\end{array}$ & $\begin{array}{l}0 \\
0 \\
0 \\
0 \\
0\end{array}$ & $\begin{array}{l}314 \\
312 \\
308 \\
312 \\
317\end{array}$ & $\begin{array}{l}0.0942 \\
0.0657 \\
0.0503 \\
0.0397 \\
0.0347\end{array}$ & $\begin{array}{l}1.19 \\
1.19 \\
1.19 \\
1.19 \\
1.19\end{array}$ & $\begin{array}{l}7.65 \\
5.72 \\
4.68 \\
3.80 \\
3.10\end{array}$ & $\begin{array}{l}81.9 \\
78.0 \\
73.7 \\
72.2 \\
78.0\end{array}$ \\
\hline $\begin{array}{l}190 \\
200 \\
210 \\
220 \\
240\end{array}$ & $\begin{array}{l}85 \\
85 \\
84 \\
84 \\
84\end{array}$ & $\begin{array}{l}2 \\
2 \\
2 \\
2 \\
2\end{array}$ & $\begin{array}{l}315 \\
314 \\
292 \\
294 \\
317\end{array}$ & $\begin{array}{l}0.1062 \\
0.0770 \\
0.0576 \\
0.0433 \\
0.0565\end{array}$ & $\begin{array}{l}1.19 \\
1.19 \\
1.19 \\
1.19 \\
1.19\end{array}$ & $\begin{array}{l}7.65 \\
5.80 \\
4.78 \\
3.60 \\
4.72\end{array}$ & $\begin{array}{l}92.3 \\
90.0 \\
82.6 \\
83.4 \\
82.0\end{array}$ \\
\hline $\begin{array}{l}250 \\
260 \\
270 \\
280\end{array}$ & $\begin{array}{l}86 \\
86 \\
86 \\
86\end{array}$ & $\begin{array}{r}3.5 \\
3.5 \\
3.6 \\
3.6\end{array}$ & $\begin{array}{l}322 \\
322 \\
319 \\
319\end{array}$ & $\begin{array}{l}0.3920 \\
0.0702 \\
0.0545 \\
0.0440\end{array}$ & $\begin{array}{l}1.20 \\
1.20 \\
1.20 \\
1.20\end{array}$ & $\begin{array}{l}7.95 \\
5.75 \\
4.80 \\
3.80\end{array}$ & $\begin{array}{l}88.6 \\
82.8 \\
77.8 \\
80.2\end{array}$ \\
\hline $\begin{array}{l}310 \\
320 \\
330 \\
360 \\
370 \\
380 \\
390\end{array}$ & $\begin{array}{l}79 \\
79 \\
79 \\
76 \\
76 \\
76 \\
76\end{array}$ & $\begin{array}{l}2 \\
2 \\
2 \\
0 \\
0 \\
0 \\
0\end{array}$ & $\begin{array}{l}315 \\
319 \\
313 \\
323 \\
325 \\
323 \\
323\end{array}$ & $\begin{array}{l}0.0780 \\
0.0648 \\
0.0474 \\
0.0750 \\
0.0582 \\
0.0432 \\
0.0322\end{array}$ & $\begin{array}{l}1.19 \\
1.19 \\
1.19 \\
1.19 \\
1.19 \\
1.19 \\
1.19\end{array}$ & $\begin{array}{l}5.78 \\
4.78 \\
3.80 \\
5.78 \\
4.78 \\
3.80 \\
3.10\end{array}$ & $\begin{array}{l}91.5 \\
92.8 \\
86.4 \\
88.0 \\
83.4 \\
78.7 \\
72.4\end{array}$ \\
\hline
\end{tabular}

